\title{
The Potential of Selected Agri-Food Loss and Waste to Contribute to a Circular Economy: Applications in the Food, Cosmetic and Pharmaceutical Industries
}

\author{
Lady Laura Del Rio Osorio ${ }^{1}$ (D) Edwin Flórez-López ${ }^{2}$ and Carlos David Grande-Tovar ${ }^{3, * \mathbb{D}}$ \\ 1 Programa de Ingeniería Agroindustrial, Facultad de Ingeniería, Universidad del Atlántico, \\ Puerto Colombia 081008, Colombia; 1ldelrio@mail.uniatlantico.edu.co \\ 2 Grupo de Investigación en Química y Biotecnología QUIBIO, Universidad Santiago de Cali, Calle 5 No 62-00, \\ Cali 760035, Colombia; edwin.florez00@usc.edu.co \\ 3 Grupo de Investigación en Fotoquímica y Fotobiología, Programa de Química, Facultad de Ciencias Básicas, \\ Universidad del Atlántico, Puerto Colombia 081008, Colombia \\ * Correspondence: carlosgrande@mail.uniatlantico.edu.co; Tel.: +57-5-3599484
}

check for updates

Citation: Osorio, L.L.D.R.;

Flórez-López, E.; Grande-Tovar, C.D. The Potential of Selected Agri-Food Loss and Waste to Contribute to a Circular Economy: Applications in the Food, Cosmetic and Pharmaceutical Industries. Molecules 2021, 26, 515. https://doi.org/ $10.3390 /$ molecules 26020515

Academic Editor:

Domenico Trombetta

Received: 13 December 2020

Accepted: 13 January 2021

Published: 19 January 2021

Publisher's Note: MDPI stays neutral with regard to jurisdictional claims in published maps and institutional affiliations.

Copyright: (c) 2021 by the authors. Licensee MDPI, Basel, Switzerland. This article is an open access article distributed under the terms and conditions of the Creative Commons Attribution (CC BY) license (https:// creativecommons.org/licenses/by/ $4.0 /)$.

\begin{abstract}
The food sector includes several large industries such as canned food, pasta, flour, frozen products, and beverages. Those industries transform agricultural raw materials into added-value products. The fruit and vegetable industry is the largest and fastest-growing segment of the world agricultural production market, which commercialize various products such as juices, jams, and dehydrated products, followed by the cereal industry products such as chocolate, beer, and vegetable oils are produced. Similarly, the root and tuber industry produces flours and starches essential for the daily diet due to their high carbohydrate content. However, the processing of these foods generates a large amount of waste several times improperly disposed of in landfills. Due to the increase in the world's population, the indiscriminate use of natural resources generates waste and food supply limitations due to the scarcity of resources, increasing hunger worldwide. The circular economy offers various tools for raising awareness for the recovery of waste, one of the best alternatives to mitigate the excessive consumption of raw materials and reduce waste. The loss and waste of food as a raw material offers bioactive compounds, enzymes, and nutrients that add value to the food cosmetic and pharmaceutical industries. This paper systematically reviewed literature with different food loss and waste by-products as animal feed, cosmetic, and pharmaceutical products that strongly contribute to the paradigm shift to a circular economy. Additionally, this review compiles studies related to the integral recovery of by-products from the processing of fruits, vegetables, tubers, cereals, and legumes from the food industry, with the potential in SARS-CoV-2 disease and bacterial diseases treatment.
\end{abstract}

Keywords: agri-food waste valorization; antioxidants; bioactive compounds; circular economy; colorants; fruit seeds; fruit peel

\section{Introduction}

The shortage of raw materials in food production worldwide has generated an environmental, economic, and social imbalance, causing the indiscriminate exploitation of natural resources, the rise in the cost of food products, and the daily increase in the number of people who suffer from extreme hunger [1]. According to the World Food Program (WFP), approximately 250 million people suffer from extreme hunger worldwide, falling behind the goal of reaching zero hunger by 2030 [2]. The current model of the economy (linear model) is based on the model inherited from the industrial revolution under the concept of the constant supply of products with a short useful life, forcing to produce more to satisfy the consumer's constant needs. The linear economy (extract, manufacture, and disposal) increases the indiscriminate exploitation of limited natural resources that would give way to a significant environmental and economic crisis $[3,4]$. 
The by-products of the agri-food industry (peels, seeds, shells, pomace, and leaves) are useful due to their content of bioactive compounds (phenols, peptides, carotenoids, anthocyanins, and fatty acids), fibers, and enzymes of great interest for the production of functional foods and drugs against acute and chronic diseases, and antioxidants that can be applied to the cosmetic industry [5]. These by-products are those food losses and waste (FLW) that, according to FAO, refer to their decline in the successive food production supply chain for human consumption [6].

The generation of FLW worldwide is much higher in developed countries. According to Van der Werf and Gilliland [7], are produced $198.9 \mathrm{~kg} /$ year per capita of FLW in developed countries. In the United States, the FLW covers $40 \%$ of the whole food production chain [8]. North Africa and West and Central Asia account for $32 \%$ of the global FLW volume [9]. The European continent represents a third (20\%) of the FLW generated worldwide [10], while in Latin America, FLW is estimated as $15 \%$ of total food production, which represents $6 \%$ of FLW worldwide [11]. Therefore, the generation and accumulation of FLW imply a significant impact on biodiversity, human health, and climate change [12]. For example, a $60 \%$ increase in greenhouse gas emissions [13] and malnutrition in the population are examples of negative impacts of FLW generation [14].

For the proper management of these by-products, it is necessary a decisive change for the agri-food system. The circular economy promises to be an efficient option in the medium and long term to prevent, reuse, or recover natural resources and derived byproducts [15]. The goal is to re-introduce the by-products to the production line as raw material for obtaining new products with high health benefits and added value in the industry through sustainable technology to extract nutritional components [16].

On the other hand, the health crisis currently being experienced worldwide by the COVID-19 disease has impacted the food system within production processes [17]. Consequently, research has been carried out to generate alternatives for eliminating the virus and improving the food system to supply the world population [18,19]. For this reason, one of the objectives of this review is to compile various studies related to the integral recovery of by-products from the processing of fruits, vegetables, tubers, cereals, and legumes in the food industry, showing the potential of phenolic compounds present in their by-products in the SARS-CoV-2 virus and bacterial diseases treatments. Noteworthy is also the review of various works that obtained bioactive components, fibers, enzymes, and flours for their functional foods and the cosmetic industry's application. This review is also intended to contribute to the paradigm-shifting towards a circular economy by highlighting various studies around the world that demonstrate the value and application of these wastes in other industries, reducing the indiscriminate disposal of waste.

\section{Circular Economy}

According to the demographic report, the world population stands at 7625 million people, with an annual growth rate of approximately 74 million people [20]. The United Nations (UN) has estimated that by 2050 the population will reach 9.2 billion people [20]. The current economic model (linear economy) has allowed rapid industrial and cultural development. However, its extracting, consuming, and disposal structure negatively impacts the availability of natural resources that supply the world population. Population growth also generates more natural resources and food consumption. Despite this, current resources are limited to supply the necessary food for the growing population and the generation of large amounts of waste [21]. These wastes are transported to sanitary landfills every year, reducing the available land for agriculture, causing damage to health and the environment [15]. In response to the problem, the use (or reuse) of waste would facilitate food supply to the growing population, reducing the indiscriminate use of human consumption resources [22]. The circular economy drastically transforms the culture and the system of extraction, production, and consumption towards a system of restoration and regeneration of natural resources' value, limiting the excessive use of raw materials and energy and avoiding the unnecessary generation of waste [23]. In the circular economy, a 
system is established where the products are designed in such a way that the generation of waste is minimal or wholly eliminated, implementing a culture in which the product is designed to give it a second useful life, with added value and also, the reduction of energy and raw material consumption [24].

The transition towards a circular economy involves various social, economic, and environmental spheres, which generate opportunities for regeneration, renewal, and innovation in the agri-food industries, protecting the scarcity of resources [25]. The integration of higher income from circular activities and the minimization of manufacturing costs would affect demand, supply, and prices, generating indirect effects that accelerate the economy's total growth and varying in favorable terms of GDP [26,27]. In the same way, high-quality recycling activities and skilled jobs in the transformation and remanufacturing of food losses and waste creating jobs through the development of local reverse logistics with SMEs generating net savings in raw material costs adopting a circular model [28].

In the environment, the circular economy directly influences the exploitation and deterioration of the ecosystem, reducing little by little to a null point, the excessive consumption of synthetic materials, such as fertilizers, pesticides, fuel, and non-renewable electricity that generate significant damage by polluting the air, soil, and water [29]. Likewise, circular economy generates a reduction of residues in the food chain by improving productivity and technology applied in the transformation and regeneration processes of natural materials, making responsible use of soil, aquatic resources, and the reduction of carbon dioxide emissions [30]. The circular economy's social aspects have a drastic impact on the current culture of food consumption, with lower amounts of waste in homes and greater use of natural and energy resources [24]. In the same way, giving a second utility to packaging by the consumer $[31,32]$. The problem of social inequality caused by poverty and famine would decrease, obtaining more affordable food and greater availability of jobs due to the new circular technological systems and the creation of companies in conjunction with local industries, forming a fabric that will improve the quality of food products and consumer satisfaction $[33,34]$.

The aspects that currently focus on the circular economy are guided by the Ellen MacArthur Foundation's butterfly diagram, based on two elements capable of processing everything that surrounds us in such a way that nothing is thrown away or wasted [35]. These elements are divided into technical and biological cycles. What belongs to the biological cycle must be compostable (compost for the soil) or used to generate biogas (gas obtained from the decomposition of organic waste). On the other side, everything is recycled without losing quality through maintenance, remanufacturing, or reuse [36]. However, the diagram focused on a completely closed and consecutive cycle is hardly executable in the economy due to the increase in energy costs and unavoidable material losses [37]. Velenturf et al. [38] propose an integrated diagram in which the production-consumption system and the biophysical environment are related to the environment and the aspects determined in the circular economy. This diagram is based on the integration of avoidable waste and industrial materials within the production system. The uncontrolled biophysical environment relates to the human being's production and consumption system, using the biophysical environment's natural resources, turning them into industrial products. In this way, the biological (natural) and technological (industrial) terms are replaced. Raw materials can be of natural or industrial origin, forming part of biological and chemical processes for their reincorporation in the biophysical environment. Industrial materials are redesigned at the end of their useful life and do not affect the biophysical environment. Those that do not need to be redesigned are reintegrated, reducing uncontrolled leaks of waste by redesigning the production and consumption system's infrastructure.

Incorporating this proposal in the food production processes would expand the circular economy concept because there are avoidable and unavoidable losses and waste in the food system. According to the Food and Agriculture Organization of the United Nations (FAO), waste can be classified as waste and losses. Losses occur during agricultural production and processing, while waste occurs during consumer consumption [92]. Therefore, 
food losses occur in the first four stages of processing, and the 5th stage is determined by consumer waste [39]. The integration of natural and industrial materials of Food Losses and Waste (FLW) is developed in a sustainable process where avoidable waste (food in the optimal condition that is not consumed) is not left aside, which can be returned to the environment (Figure 1).

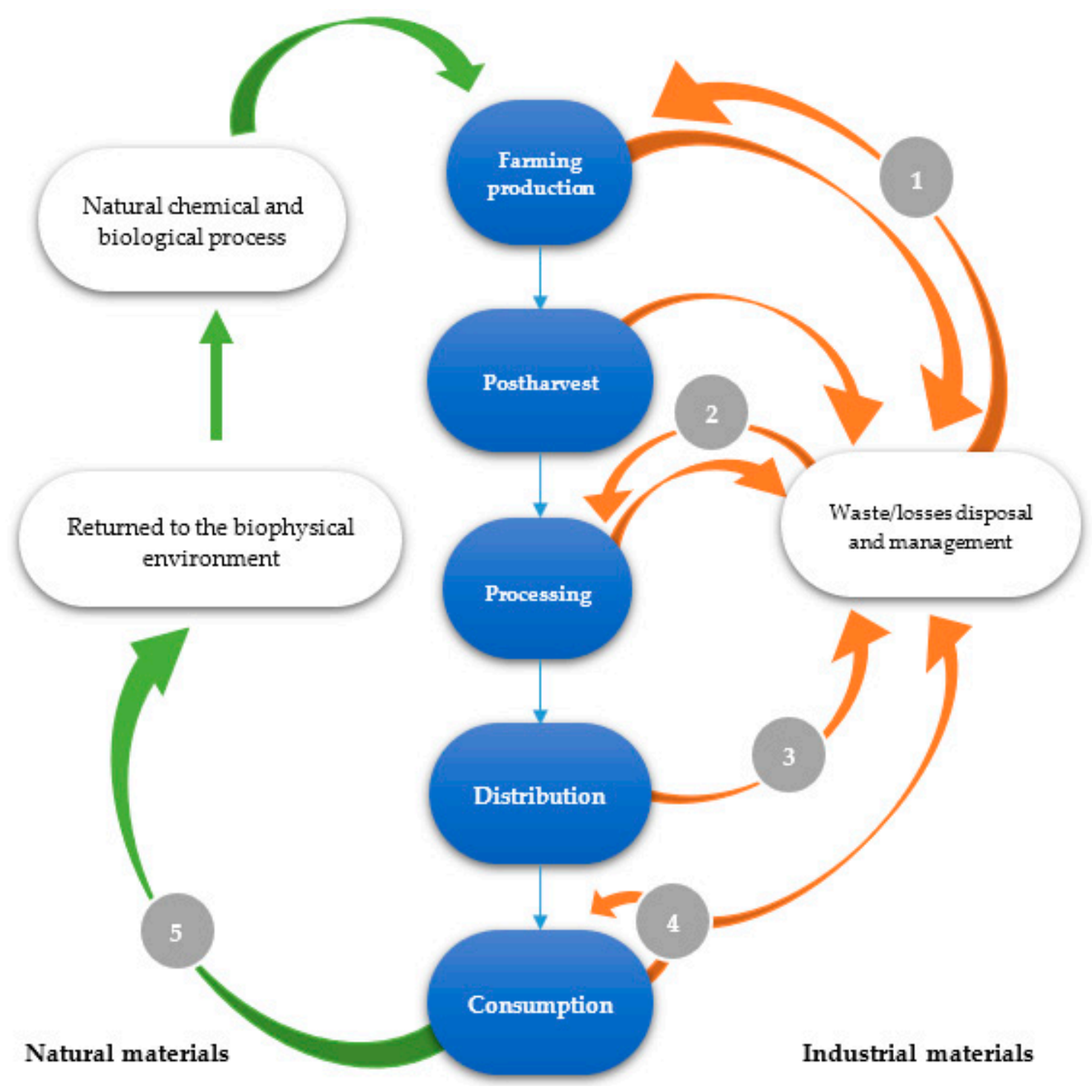

Figure 1. General scheme of waste and losses of the food chain in the circular economy: (1) Raw material recovery. (2) Modification and transformation of losses. (3) Reincorporation of food waste and losses. (4) Reuse of packaging.

(5) Reincorporated food waste [38,39].

Based on legal aspects, the analysis or treatment of food waste in a circular economy should focus on each country's applicable laws [40,41]. Within the legal framework of the European Union (EU) in a global context of regulations and policies for the efficient use of resources and sustainable patterns of consumption and production, it plans to develop advanced routes of different recovery (incorporation into the food industries) to the usual processes (Animal feeding, composting and anaerobic digestion) [42,43]. The reuse and minimization of food waste will be dealt with, provided that these are suitable for human consumption and do not generate toxicity during their treatment [44].

The Treaty on the Functioning of the European Union contemplates the international transport of waste, which under this regulation waste is classified to determine its valuation and reuse subsequently. Agri-food waste (such as peels, seeds, vegetable, and cereal 
residues) are classified as "green list," which are determined as non-infectious, and it is planned to incorporate them into the treatment process $[45,46]$. In the transition to a circular economy, the European Parliament initiated the regulation of the product's life cycle in its entirety, from primary production to waste in conjunction with the management and market of secondary raw materials (food by-products) $[47,48]$. Countries such as Germany, France, and Italy, in the face of established regulations, have promoted government initiatives for the use of food waste that are not suitable for human consumption in the production of feed and composting [49].

In Japan, the Food Recycling Law was established in 2001 [50], which establishes that companies and industries in the food chain (from agricultural production to consumption) are participants in reusing waste and reducing food waste. This law encouraged companies such as Eco-Farm to use plant residues from food industries to make organic fertilizers that are used in crops that supply the raw material in food production [51]. In countries such as Korea, Taiwan, and Thailand, food waste is promoted and regulated by-laws to feed for ruminants, pigs, and poultry [52].

\section{Popular Technologies for the Re-Use of Food Loss and Waste from the Agri-Food Sector}

Food waste currently generates the main problem for natural resources, causing shortages, instability in the environment, and damage to public health through their poor disposal [53]. For many years the solution has been to dispose of them in sanitary landfills or otherwise burn them to reduce the amount of waste accumulated in these lands [54]. Due to this problem, some countries worldwide have developed and implemented technologies to generate the most effective use and recovery of food waste (Table 1), avoiding its disposal to landfills and reducing this waste [55]. In Europe, there is a broad practice of treatment of food waste through composting as the anaerobic digestion, due to European legislation that restricts the final disposal of the organic fraction without prior processing (Directive 1999/31/EC of 26 April 1999) [56,57].

The leading countries are Germany, Spain, and Switzerland [58]. In the European Union, approximately 30 million tons of separately collected food waste are composted or digested annually in almost 3500 treatment plants [59]. Pruning waste accounts for more than $50 \%$ of food waste, which is processed in more than 2000 composting plants, which is the system that dominates over anaerobic digestion, resulting in $90 \%$ of the treatment of food waste [60]. Compost production is relatively easy and inexpensive to implement on a local, national and regional scale, and it can be accompanied by biogas production, increasing the economic value generated per treated ton of food waste [61]. Additionally, biogas production for energy purposes through anaerobic digestion is considered an energy recovery technique from food waste [62]. 
Table 1. Technologies used in several countries around the world for the re-use of food waste.

\begin{tabular}{|c|c|c|c|c|c|}
\hline Technology & Countries & Advantage & Disadvantage & Product & References \\
\hline Anaerobic digestion & $\begin{array}{l}\text { United States, Germany, } \\
\text { Switzerland, Italy, Spain, } \\
\text { and Norway }\end{array}$ & $\begin{array}{l}\text { An utterly harmless end product rich } \\
\text { in nutrients is obtained and can be } \\
\text { used in agriculture. Solid matter is } \\
\text { reduced in the digestion. The gas } \\
\text { generated in the stabilization of solids } \\
\text { can be used as an energy source. } \\
\text { As the tanks are closed, there are no } \\
\text { terrible odors outside the premises. } \\
\text { During the stabilization process, } \\
\text { pathogens and individual parasitic } \\
\text { organisms are eliminated }\end{array}$ & $\begin{array}{l}\text { Requires high amounts of } \\
\text { water. It is a slow process that } \\
\text { requires more time. Requires } \\
\text { more energy in processes }\end{array}$ & $\begin{array}{c}\text { Biogas and liquid effluent } \\
\text { used as compost }\end{array}$ & {$[60,63-65]$} \\
\hline $\begin{array}{l}\text { Composting and } \\
\text { vermicomposting }\end{array}$ & $\begin{array}{l}\text { Germany, Switzerland, Italy, } \\
\text { Spain, Norway, South Korea, } \\
\text { Japan, and several Latin } \\
\text { American countries }\end{array}$ & $\begin{array}{l}\text { Reduces the use of inorganic fertilizers. } \\
\text { Saves irrigation water due to the water } \\
\text { holding capacity of the compost. } \\
\text { Provides the necessary nutrients for } \\
\text { the development of plants naturally }\end{array}$ & $\begin{array}{l}\text { In the more advanced } \\
\text { industrial processes, the use of } \\
\text { energy can be considerable, } \\
\text { presenting high costs }\end{array}$ & $\begin{array}{l}\text { Fertilizer and compost } \\
\text { for crops }\end{array}$ & {$[60,63,65]$} \\
\hline WTE-Waste to Energy & $\begin{array}{l}\text { Germany, Switzerland, Italy, } \\
\text { Spain, Norway, South Korea, } \\
\text { and Japan }\end{array}$ & $\begin{array}{l}\text { Avoid methane emissions } \\
\text { caused by landfills. } \\
\text { They offset greenhouse gas emissions } \\
\text { caused by the production of electricity } \\
\text { from fossil fuels. } \\
\text { Recover/recycle valuable resources }\end{array}$ & $\begin{array}{l}\text { It is an expensive process. It } \\
\text { pollutes the environment due } \\
\text { to incinerators that produce } \\
\text { smoke during the } \\
\text { combustion process }\end{array}$ & Energy & {$[60,66,67]$} \\
\hline $\begin{array}{l}\text { MBT- Mechanical } \\
\text { Biological Treatment }\end{array}$ & $\begin{array}{c}\text { Germany, Spain, Switzerland, } \\
\text { Korea, and Japan }\end{array}$ & $\begin{array}{l}\text { Confined material is inert. } \\
\text { Conservation of resources and } \\
\text { reduction of emissions harmful } \\
\text { to the environment }\end{array}$ & $\begin{array}{l}\text { Potential for odor problems. } \\
\text { A variety of occupational } \\
\text { health and safety problems }\end{array}$ & $\begin{array}{l}\text { A stabilized organic fraction, } \\
\text { recovered combustible solid } \\
\text { products, materials } \\
\text { ferrous/non-ferrous and biogas }\end{array}$ & {$[60,68,69]$} \\
\hline Feed production & $\begin{array}{c}\text { Germany, France, Italy, Korea, } \\
\text { and Japan }\end{array}$ & $\begin{array}{l}\text { Reduce pollution and } \\
\text { environmental impact } \\
\text { that these products generate when } \\
\text { they are thrown away as waste. } \\
\text { Possibility of reducing production } \\
\text { costs in specific diets. } \\
\text { Provide the animal with a rich source } \\
\text { of protein and energy }\end{array}$ & $\begin{array}{l}\text { Seasonality and variability } \\
\text { of production } \\
\text { There must be a previous study } \\
\text { for the compatibility between } \\
\text { the animal and the feed. } \\
\text { There must be a regulation for } \\
\text { detailed control of food, } \\
\text { traceability, and food safety }\end{array}$ & Animal feeding & {$[60,63,65]$} \\
\hline
\end{tabular}




\section{Agri-Food Industry}

The agri-food industry is structured by the primary sector dedicated to agriculture, fishing, livestock, forestry, and the agri-business, where raw materials' processes and transformations (from the primary sector) into semi-finished products occurs for human consumption [70]. Similarly, this industry is subdivided according to the primary sector's different activities and the raw material's processing. Within processing, there are the dairy industry, the fruit and vegetable industry, the milling industry, the meat industry, the fish and seafood industry, the oil and fat industry, and the beverage industry, including alcoholic beverages [71]. Over time, commerce and the agri-food industry have been characterized by technological innovations implementing efficient production processes, pursuing cost reduction and competitiveness in the global market. The main goal is to satisfy the needs of the different population segments through technical and efficiency improvements [72].

The agricultural sector's production processes in the agri-food industry involve transforming the raw material and subsequent distribution to the consumer (Figure 2). These stages are developed from the cultivation phase, where sowing systems are carried out according to the type of raw material to be cultivated, intensively (higher production in little space) and extensively (in greater surface area) [73]. Subsequently, harvesting (depending upon the fruit, the goal product, maturation stage, among others) is maintained at temperatures and humidity required to preserve the useful life in the distribution and consumption stages [74]. More than 5000 million metric tons of agricultural raw material are processed, obtaining millions of products globally [75].

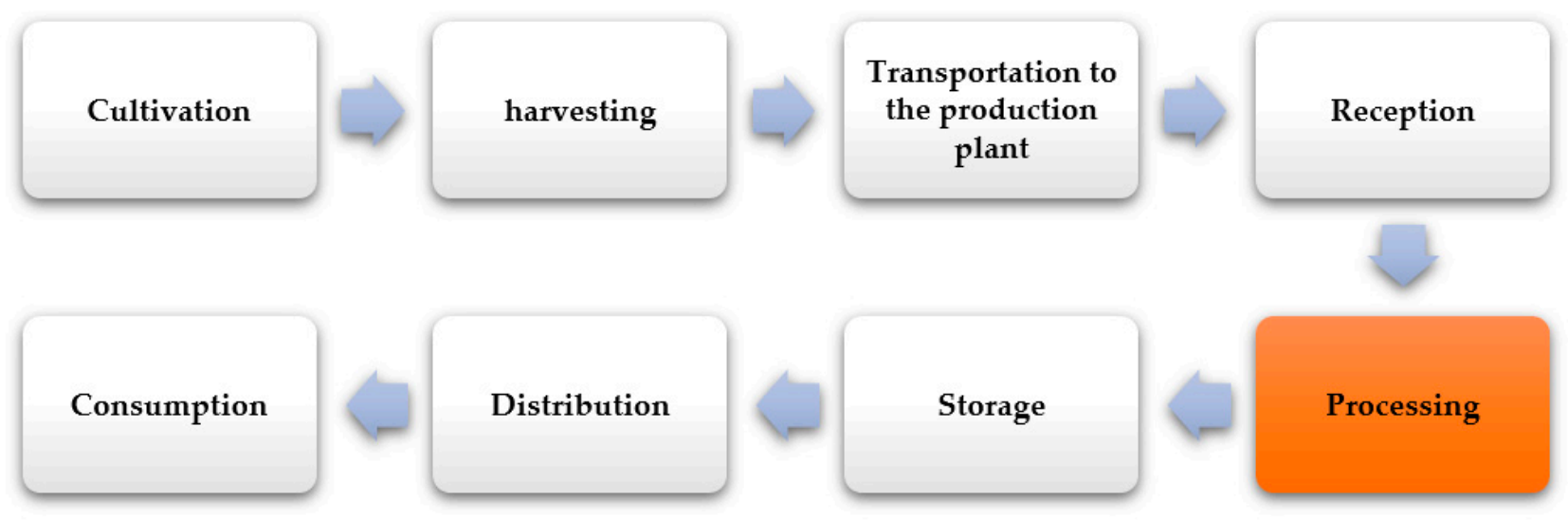

Figure 2. Scheme of the productive chain of the agri-food industry. Source: Adapted from [76].

On the other hand, the high number of products generated in the market, the lack of technological innovations in the processing of raw materials and infrastructure, inadequate food safety protocols, overcooking, unwanted sizes and weights in food, the defects of the packaging and labeling, are aspects that contribute to the food waste generation during the food supply chain, also with bad cultural habits for the purchases and consumption [77]. A large amount of waste generated worldwide is a big concern for governments and policymakers because of the immense contribution to environmental, economic, and social problems [78]. These wastes are generally unproperly used. On the contrary, they are discarded to landfills that increasingly occupy more land, contaminating soils, surface, and underground waters, increasing the ecosystem's imbalance due to the agricultural sector's indiscriminate production [79]. For this reason, it is necessary to study their chemical composition and their potential to introduce them as a raw material in several industrial processes, evolving towards a circular economy [78]. Following the above, this section will discuss the different agricultural industries such as the fruit and vegetable industry, the tuber industry, and the cereal and legume industry, establishing the production data, the operational processes where the residues are generated, and their main components. 


\subsection{Fruit and Vegetable Production}

One of the industries with the highest production globally is horticulture, covering approximately $38 \%$ of agricultural production and $65 \%$ of vegetable production in the agrifood industry [80]. Among the primary fruit and vegetable producer countries are China, India, Turkey, and the United States (Figure 3). According to the Food and Agriculture Organization of the United Nations (FAO), during 2018, the production of fruits and vegetables worldwide exceeded 1800 million tons, increasing by $1.53 \%$ compared to the year 2017, and it is estimated that for the period 2020-2021 a considerable percentage will decrease due to the pandemic crisis of the COVID-19 disease that affects agri-food production globally $[81,82]$.

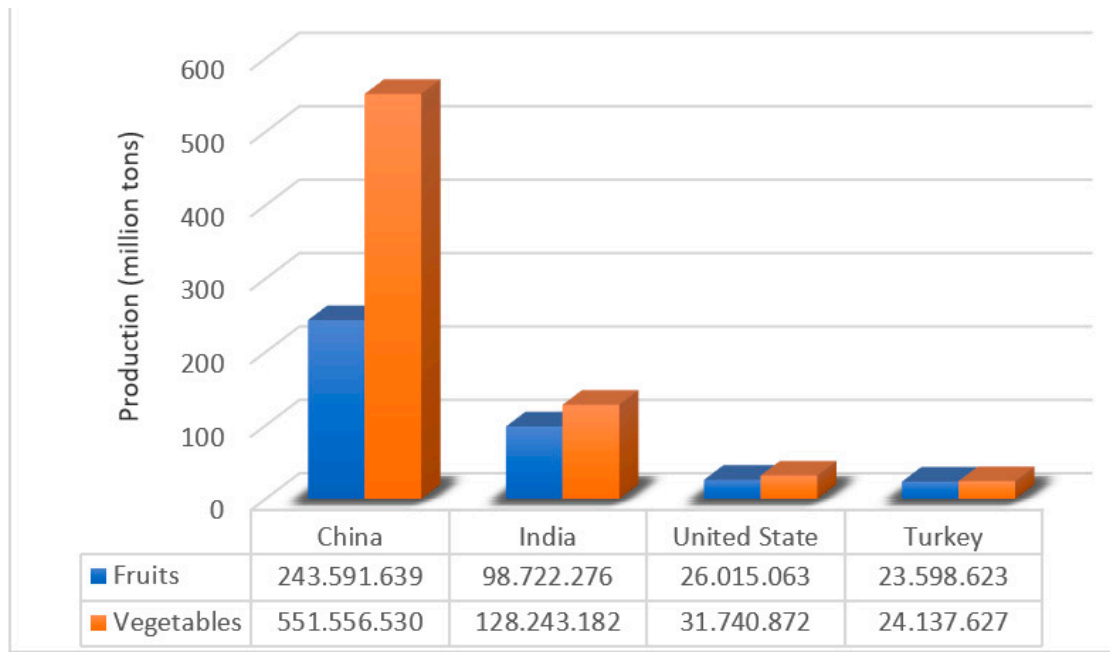

Figure 3. Primary fruit and vegetable producer (2018 production) [81].

Among the fruits and vegetables with the highest production are tomato (Solanum lycopersicum), apple (Malus domestica), onion (Allium cepa), orange (Citrus $\times$ sinensis), Cole (Brassica oleracea var. Capitata), gherkin (Cucumis sativus L.), eggplant (Solanum melongena), mango (Mangifera indica), carrot (Daucus carota), guava (Psidium guajava L.), and pepper (Capsicum anuum), which are processed for the production of value-added foods in the food industry (Figure 4) [80].

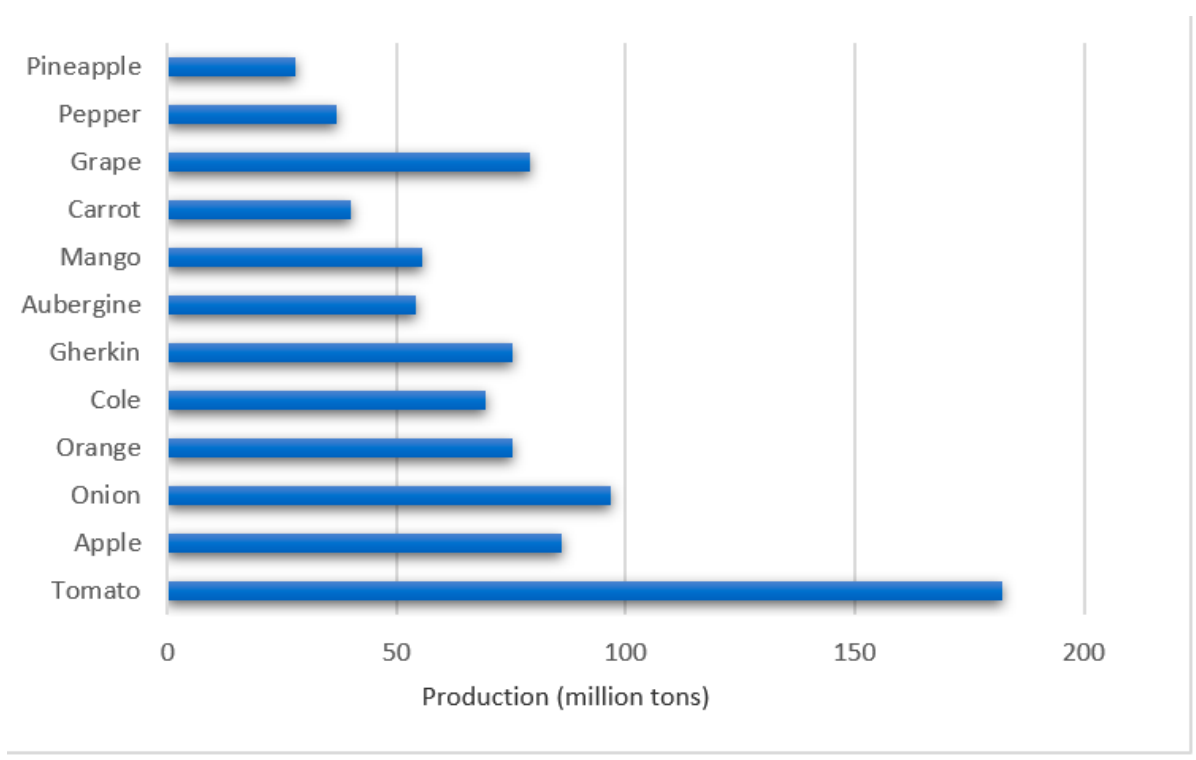

Figure 4. Fruits and vegetables with the highest production worldwide [81]. 
Within the transformation of fruits and vegetables, specific industrialization processes are developed such as dehulling or peeling, blanching, core removal, and pulping, which have temperature, humidity, and $\mathrm{pH}$ control systems for optimal conservation (Figure 5) [83]. These processes vary according to the type of fruit or vegetable and the final product obtained. However, it is possible to identify some basic transversal processes in the different industrialization processes, such as cleaning, sterilization, and pasteurization, that determine food safety [84]. The processing of fruits and vegetables is carried out to extend the shelf life and generate various food consumption options [85]. For example, various products with high-value in the market, such as preservatives, juices, jams, pasta, concentrates, and dehydrated products [86,87]. However, the horticultural industry generates significant losses of optimal raw material for human and animal consumption due to its high production. The food loss and waste correspond to biomass rich in bioactive compounds, enzymes, vitamins, and fibers, obtained through extraction processes and chemical transformation for animal and human nutrition or even to be used in biorefinery applications [88].

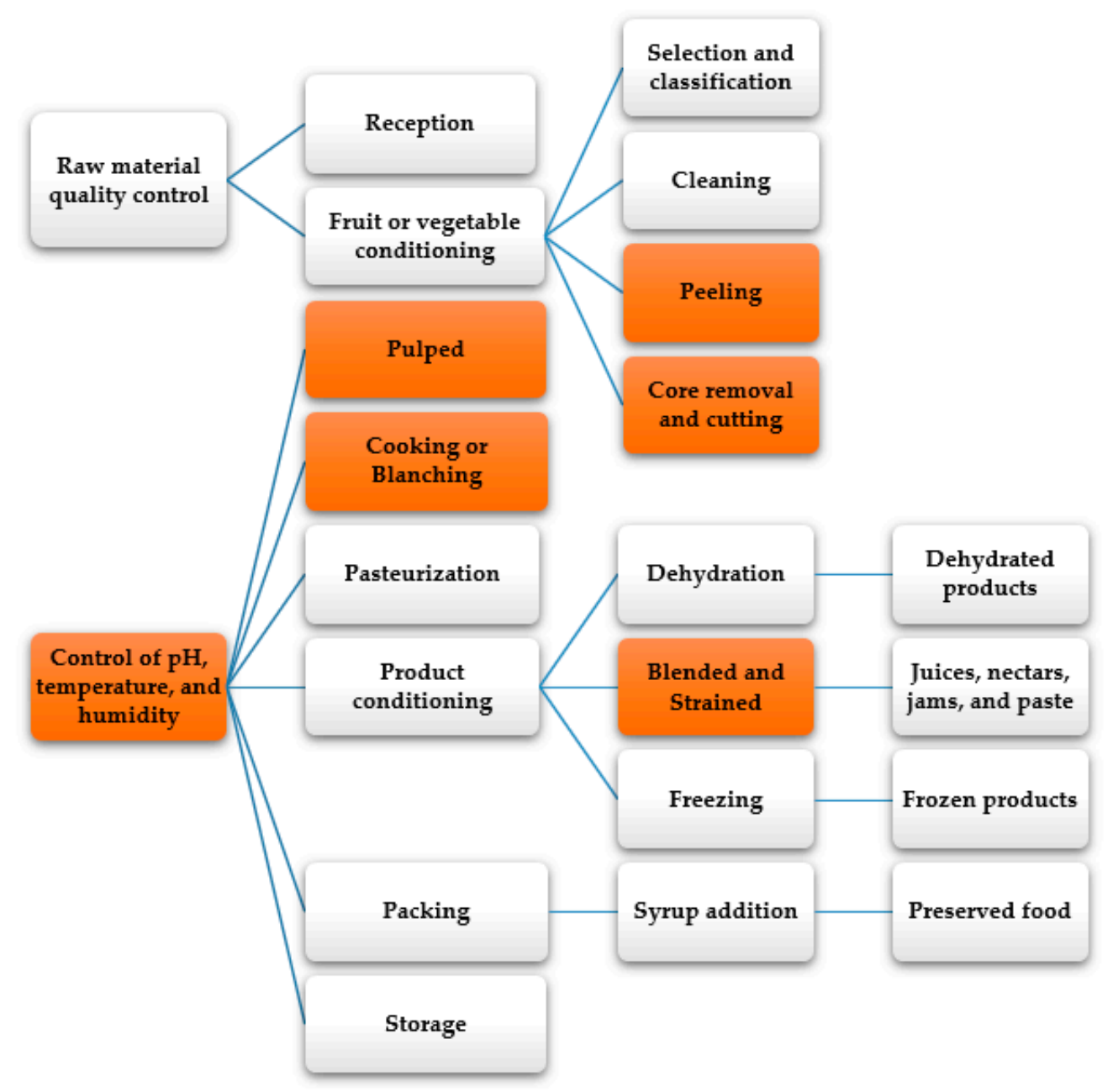

Figure 5. General diagram of fruit and vegetable industrial processing $[89,90]$.

4.1.1. Food Loss and Waste (FLW) Products from the Fruit and Vegetable Industrial Processing

The processing of fruits and vegetable generate several FLW such as peel, skin, seeds, stem, pomace, and bagasse [91]. These by-products generally come from specific processes such as pulping, peeling, straining, and blanching, necessary for food processing and conditioning [86]. However, those food losses and waste products (FLW) are not used 
in the production process. On the contrary, they are classified as waste by dumping them in sanitary landfills or leaving them in the field, increasing the deterioration of the environment and scarcity of resources and losing the opportunity to contribute to the feeding of a growing world population that with the current production of resources will not be enough [6].

According to the Food and Agriculture Organization of the United Nations (FAO), food loss and wastes in the fruit and vegetable industries amount to $60 \%$ of the total production [88], where losses represent between 3 and $50 \%$ of the total of processed raw material (Table 2). In avoiding the excessive use of natural resources, the use and valorization of these by-products are of great importance both for the environment and for the population's supply, preparing nutritional foods with health benefits, contributing to the transition from a linear to a circular economy, also known as a "bioeconomy" [91,92].

Table 2. Examples of Food Losses and Waste (FLW) generated from the processing of fruits and vegetables worldwide.

\begin{tabular}{|c|c|c|c|c|}
\hline Industrial Product & Process & By-Product & Fraction of Raw Material in Fresh Weight (\%) & References \\
\hline \multirow{2}{*}{ Canned pineapple } & Peeling & Peel & 44 & \multirow{2}{*}{ [93] } \\
\hline & Core remove & Core & 15 & \\
\hline \multirow{2}{*}{ Canned peaches } & Peeling & Peel & 8.6 & \multirow{2}{*}{ [94] } \\
\hline & Cutting & Seed & 11.4 & \\
\hline Dried apple & Core remove & Core & $2-4$ & {$[92,95]$} \\
\hline \multirow{3}{*}{ Tomato paste } & Peeling & Peel & 3 & \multirow{3}{*}[95,96]{} \\
\hline & Pulping & Seed & 7 & \\
\hline & Straining & Pomace & $10-20$ & \\
\hline \multirow{3}{*}{ Apple juice } & Peeling & Peel & 5 & \multirow{3}{*}[95,96]{} \\
\hline & Pulping & Seed & $2-4$ & \\
\hline & Straining & Pomace & $20-30$ & \\
\hline \multirow{3}{*}{ Pineapple juice } & Core remove & Core & 11 & \multirow{3}{*}{ [95] } \\
\hline & Peeling & Peel & 40 & \\
\hline & Straining & Pomace & 8 & \\
\hline \multirow{3}{*}{ Mango juice } & Peeling & Peel & $12-15$ & \multirow{3}{*}{ [96] } \\
\hline & Pulping & Seed & $15-20$ & \\
\hline & Straining & Pomace & $5-10$ & \\
\hline Peach juice & Pulping & Seed & $4-11$ & [96] \\
\hline \multirow{2}{*}{ Grapefruit juice } & Peeling & Peel & 30 & \multirow{2}{*}[96,97]{} \\
\hline & Pulping & Seed & 20 & \\
\hline \multirow{2}{*}{ Grape juice } & Straining & Pomace & 13 & \multirow{2}{*}[92,98]{} \\
\hline & Pulping & Seed & 5 & \\
\hline \multirow{3}{*}{ Orange juice } & peeling & peel & $30-40$ & \multirow{3}{*}[96,99]{} \\
\hline & Pulping & Seed & 2 & \\
\hline & Straining & Pomace & 28 & \\
\hline Carrot juice & Straining & Pomace & $30-40$ & [95] \\
\hline \multirow{2}{*}{ Passion fruit juice } & Peeling & Peel & 40 & \multirow{2}{*}{ [96] } \\
\hline & Pulping & Seed & 10 & \\
\hline \multirow{2}{*}{ Pineapple jams } & Peeling & Peel & 44 & \multirow{2}{*}[93,100]{} \\
\hline & Core remove & Core & 11 & \\
\hline Pepper jams & Core remove & Seed & $50-60$ & [99] \\
\hline \multirow{3}{*}{ Frozen mango } & Peeling & Peel & $12-15$ & \multirow{3}{*}[88,96]{} \\
\hline & Pulping & Seed & 13.5 & \\
\hline & Cutting & Discarded pulp & $5-10$ & \\
\hline \multirow{2}{*}{ Frozen melon } & Peeling & Peel & 8 & \multirow{2}{*}{ [100] } \\
\hline & Cutting & Seed & 5 & \\
\hline
\end{tabular}




\subsubsection{Peels}

Fruit and vegetable peels are generated in the peeling stage, where the pulp is separated from the raw material covering (Table 3). This operation is carried out mechanically or manually, depending on the production and technology used [101]. Currently, 500 million tons of peel residues are produced in the fruit and vegetable industry, covering from 3 to $50 \%$ of the fruit or vegetable's total fresh weight $[102,103]$. Orange (Citrus sinensis) is the fruit with the highest processing, generating 16 million tons of waste every year [103]. In general, fruit peels present a good source of cellulose, hemicellulose, and phenolic compounds with the potential to be used as raw material to generate new products [102]. The uses could include preparing animal feed organic fertilizers, cosmetic, and pharmaceutical applications due to their bioactive components such as phenols, peptides, terpenes, providing antioxidant, therapeutic, and nutritional properties [91].

Table 3. Chemical composition of fruit peels.

\begin{tabular}{|c|c|c|c|c|c|c|}
\hline Peels & $\begin{array}{c}\text { Protein } \\
\text { Crude }(g / 100 \text { g) }\end{array}$ & $\begin{array}{l}\text { Fiber Crude } \\
\text { (g/100 g) }\end{array}$ & $\begin{array}{c}\text { Ash } \\
\text { (g/100 g) }\end{array}$ & $\begin{array}{l}\text { Lipid } \\
\text { (g/100 g) }\end{array}$ & $\begin{array}{l}\text { Carbohydrate } \\
\text { (g/100 g) }\end{array}$ & Reference \\
\hline Pineapple (f.w.) & 5.11 & 14.80 & 4.39 & 5.31 & 55.52 & [104] \\
\hline Tomato (d.w.) & 11.17 & 76.13 & 3.54 & 4.48 & - & [105] \\
\hline Apple (f. w.) & 2.80 & 13.95 & 1.39 & 9.96 & 59.96 & [104] \\
\hline Mango (f.w.) & 5.00 & 15.43 & 3.24 & 4.72 & 63.80 & [104] \\
\hline Grapefruit (d.w.) & 4.22 & 1.61 & 2.99 & 2.01 & 46.44 & [106] \\
\hline Orange (f.w.) & 9.73 & 14.19 & 5.17 & 8.70 & 53.27 & [104] \\
\hline Passion fruit (d.w.) & 4.05 & 19.20 & 7.52 & 0.10 & 21.28 & [107] \\
\hline Melon (f.w.) & 9.07 & 29.59 & 11.09 & 1.58 & 48.67 & [108] \\
\hline
\end{tabular}

f.w. = fresh weight; d.w. = dry weight.

\subsubsection{Seeds}

The seed is a raw material fraction that is mostly wasted in processing fruits and vegetables. Also, they constitute between $15 \%$ and $40 \%$ of the total fruit (fresh weight). This by-product is generated in the pulping stage, where only the pulp is extracted [109]. Fruit seeds contain many nutrients such as proteins and lipids in $35 \%$ and $25 \%$, respectively (Table 4). Tomato seed, one of the most abundant residues due to its extensive production in the market for pasta and sauce preparation, provides an essential source of unsaturated fatty acids, especially linoleic acid. Likewise, lycopene is the carotenoid responsible for the fruit's red color with greater abundance in the peel $[95,110]$. On the other hand, the mango seed is a promising source of edible oil extraction and has been of great interest for its fatty acid profile similar to cocoa, butter, and as a source of phenolic compounds and phospholipids [111].

Table 4. Chemical composition of fruit and vegetable seeds.

\begin{tabular}{|c|c|c|c|c|c|}
\hline Seeds & Protein Crude (g/100 g) & Fiber $(g / 100 \mathrm{~g})$ & Ash (g/100 g) & Lipid (g/100 g) & Reference \\
\hline $\begin{array}{l}\text { Tomato } \\
\text { (d.w.) }\end{array}$ & 24.5 & 33.9 & 3.0 & 20.0 & [112] \\
\hline $\begin{array}{l}\text { Peach } \\
\text { (d.w.) }\end{array}$ & 27.85 & 60.92 & 3.41 & 1.21 & [113] \\
\hline $\begin{array}{l}\text { Apple } \\
\text { (d.w.) }\end{array}$ & 34.00 & 24.00 & 4.1 & 27.7 & [114] \\
\hline $\begin{array}{l}\text { Grape } \\
\text { (f.w.) }\end{array}$ & 6.93 & 38.60 & 4.50 & 2.87 & [115] \\
\hline
\end{tabular}


Table 4. Cont.

\begin{tabular}{|c|c|c|c|c|c|}
\hline Seeds & Protein Crude (g/100 g) & Fiber (g/100 g) & Ash (g/100 g) & Lipid (g/100 g) & Reference \\
\hline $\begin{array}{c}\text { Mango } \\
\text { (f.w.) }\end{array}$ & 7.70 & 10.23 & 2.26 & 65.46 & [116] \\
\hline $\begin{array}{l}\text { Melon } \\
\text { (d.w.) }\end{array}$ & 27.41 & 25.32 & 4.83 & 30.65 & [117] \\
\hline $\begin{array}{l}\text { Pepper } \\
\text { (d.w.) }\end{array}$ & 21.29 & 38.76 & 4.94 & 23.65 & [118] \\
\hline $\begin{array}{c}\text { Orange } \\
\text { (d.w.) }\end{array}$ & 3.06 & 5.50 & 2.50 & 54.20 & [119] \\
\hline $\begin{array}{l}\text { Passion fruit } \\
\text { (f. w) }\end{array}$ & 15.00 & 41.33 & 1.40 & 29.60 & [120] \\
\hline
\end{tabular}

f.w. = fresh weight; d.w. = dry weight.

\subsubsection{Pomace and Core Fruit}

The pomace represents the mixture between seed residues, skin, fiber, and pulp of the fruit or vegetable, generated in large quantities in the straining and pulping stage [121]. The pomace is characterized by containing a significant amount of fiber (between 40 and $60 \%$ ) and bioactive compounds (Table 5) [122]. For example, grape pomace obtained from juices and wine production represents $20 \%$ of the total processed grapes [123], providing various phenolic constituents such as catechins, anthocyanins, flavanol glycosides, phenolic acids, and stilbenes [98]. On the other hand, the pineapple core (an inevitable residue in its processing) is an essential fiber source [93]. However, it is an edible residue that can be used as a dietary source.

Additionally, it contains an enzyme called bromelain with anti-inflammatory properties. It provides a more remarkable ability to digest food in the body [124]. Also, in the food industry, it is used as a meat tenderizer, in the processing of fish and marine products such as the production of oyster sauce, in the manufacture of cookies (to eliminate gluten), as a substitute for sulphones used to prevent browning of fruit juices, in white wine and beer clarification [125]. In the same way, it is used in the pharmaceutical industry to treat dyspepsia, infections, cellulitis, edema, and cancer [126,127].

Table 5. Chemical composition of the pomace and core fruit.

\begin{tabular}{|c|c|c|c|c|c|}
\hline Fruit & Protein $(g / 100 g)$ & Fiber (g/100 g) & Ash (g/100 g) & Lipid (g/100 g) & Reference \\
\hline $\begin{array}{l}\text { Grape pomace } \\
\text { (d.w.) }\end{array}$ & 8.49 & 46.17 & 4.65 & 8.16 & [123] \\
\hline $\begin{array}{l}\text { Apple pomace } \\
\text { (f.w.) }\end{array}$ & 3.30 & 42.10 & 1.10 & 2.30 & [128] \\
\hline $\begin{array}{l}\text { Mango pomace } \\
\text { (d.w.) }\end{array}$ & 10.59 & 6.14 & 2.76 & 1.74 & [129] \\
\hline $\begin{array}{l}\text { Tomato pomace } \\
\text { (d.w.) }\end{array}$ & 19.27 & 59.03 & 3.92 & 5.85 & [130] \\
\hline $\begin{array}{l}\text { Peach pomace } \\
\text { (d.w.) }\end{array}$ & 7.50 & 54.20 & 3.00 & 3.00 & [131] \\
\hline $\begin{array}{l}\text { Pineapple core } \\
\text { (f.w.) }\end{array}$ & 0.85 & 47.60 & 1.30 & 3.17 & [132] \\
\hline $\begin{array}{l}\text { Carrot pomace } \\
\text { (d.w.) }\end{array}$ & 20.90 & 55.80 & 5.50 & 1.30 & [133] \\
\hline
\end{tabular}




\subsection{Production of the Root and Tuber Industry}

The food products with the highest proportion of carbohydrates are found in roots and tubers derivatives such as potato (Solanum tuberosum), yam (Dioscorea esculenta), and cassava (Manihot esculenta). They are considered essential foods due to their healthy nutrients content with an antioxidant, antimicrobial, hypoglycemic, and immunomodulatory capacity based on bioactive compounds such as phenols, saponins, bioactive proteins, and phytic acids [134]. This industry has an annual production of 820 million tons, mainly consumed in developing countries due to its low cost and caloric input [81]. Africa's consumption is approximately 120 million tons, constituting $15 \%$ of world production, followed by the Asian continent and Latin America, with a consumption of 13 and 5\%, respectively [135]. On the other hand, $40 \%$ of the production is industrialized for elaborating products with added value in the market [135], corresponding to flours, starches, fresh and processed products, with a demand of more than USD 92.12 billion [136-138]. These foods are used both for fresh consumption and as a raw material in the industry for the production of additives $(10 \%)$, frozen products $(40 \%)$, snacks $(10 \%)$, bakery $(25 \%)$, and pastries (15\%) [136,139].

Among the leading world producers of tubers is China, with $39 \%$ of the total production, followed by Nigeria (30\%), India (14\%), Thailand (9\%), and the Congo (8\%) (Figure 6). Of the world production of roots and tubers, approximately 332 million tons of raw material are processed in the food industry [134]. Traditionally, tubers are marketed as fresh products, but due to the growing demand for production, new products have been developed, expanding their application forms [140]. Within the variety of most processed tubers are potato (Solanum tuberosum), cassava (Manihot esculenta), sweet potato (Ipomoea batatas), and yam (Dioscorea alata) [134], developing products as a functional ingredient in the industries of bread, flour, and fermented beverages such as beer [141].

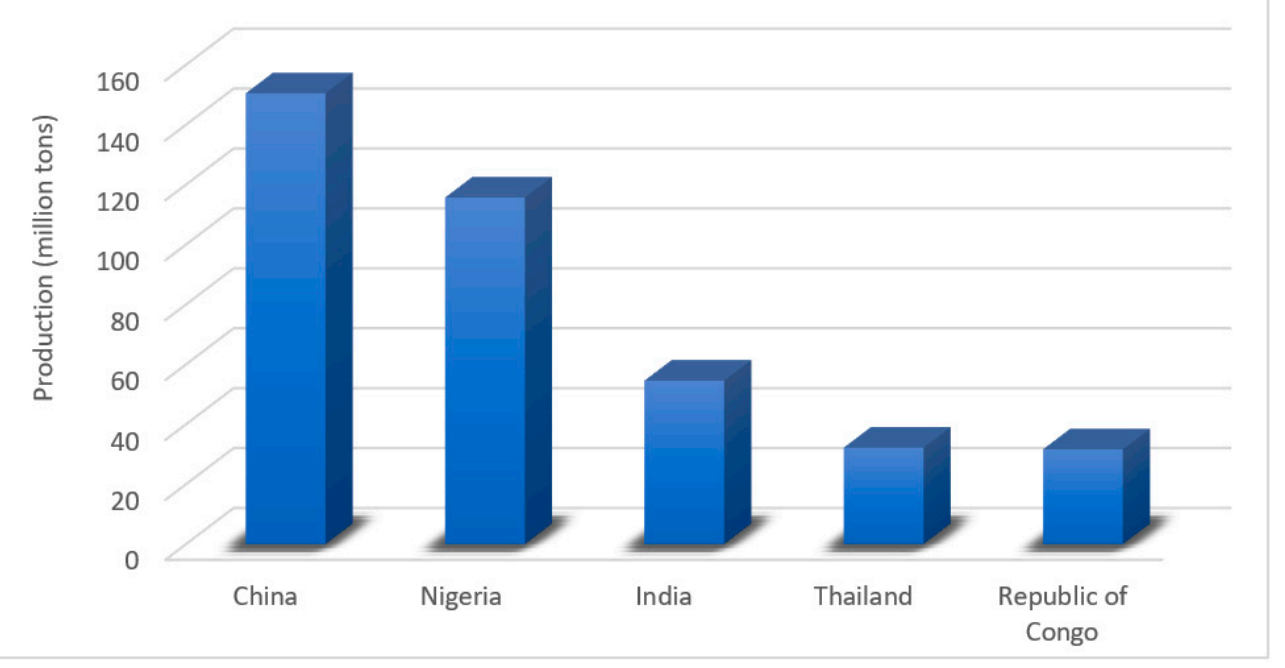

Figure 6. The five leading producer countries of roots and tubers in 2018 [81].

The tubers' transformation process varies according to the target product, use, variety, and tuber type (Figure 7) [142]. Generally, the most common processes are characterized by simple physical methods for maintaining the fresh product's organoleptic properties [143]. The food conditioning has staged peeling, chopping, and reducing the particle size to produce starch or flours. These flours are used both in the preparation of homemade foods such as tortillas, arepas, fritters, cakes, among others, and in the industry of products for direct consumption such as bread, desserts, and instant soups [143]. Starch is the main cassava processing product used as raw material and ingredient for producing foodprocessed products such as bread, instant soups, rice, frozen products, and processed 
fruits [144]. It is estimated that starch production will increase annually, up to 376,000 tons globally, for its commercialization during 2019-2024 [145].

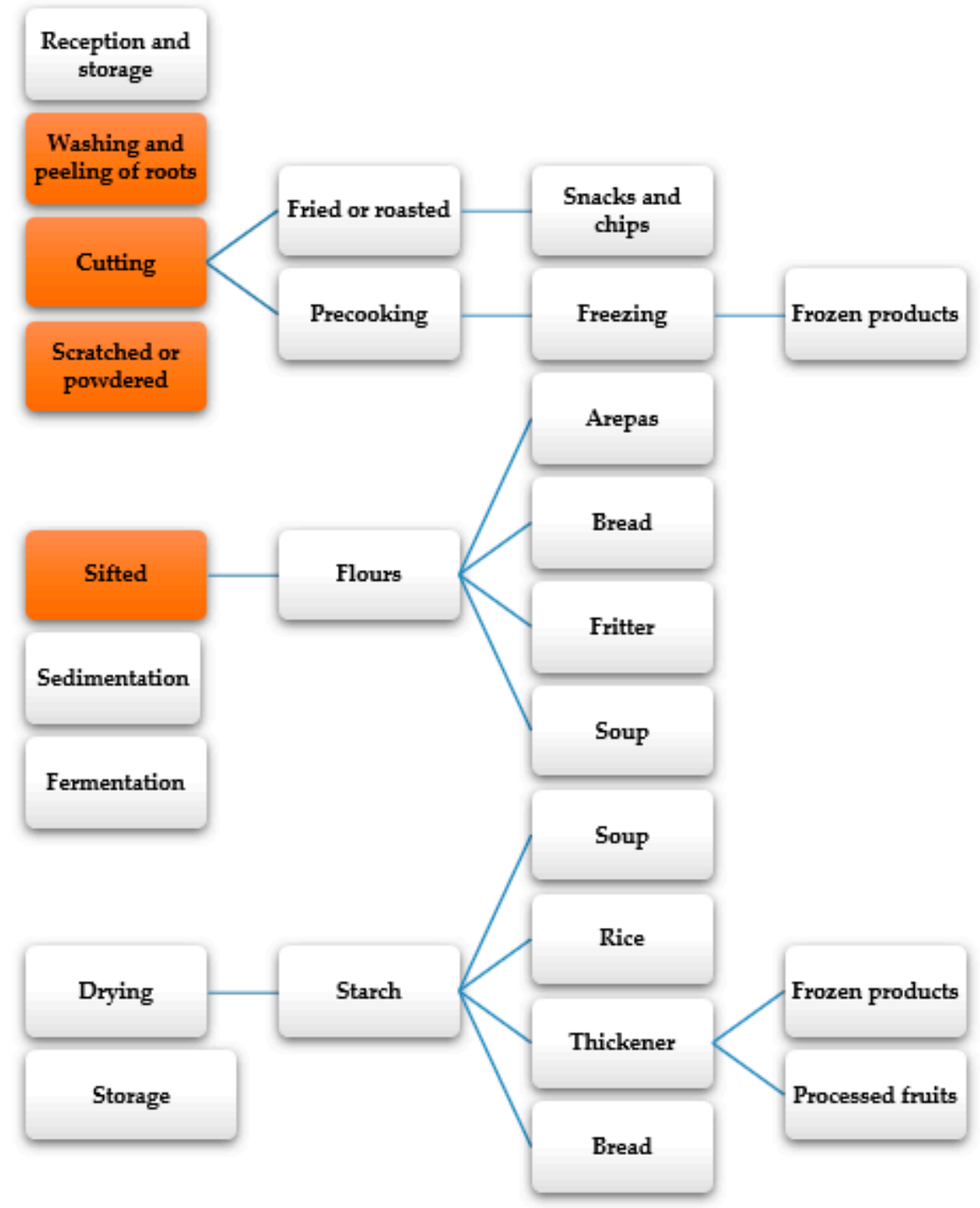

Figure 7. General scheme of root and tuber processing $[143,144]$.

4.2.1. Food Loss and Waste (FLW) Products from the Root and Tuber Industry

An estimated 320 million tons of tubers are globally processed every year, a secondplace after food grains processing, required as an essential energy source [134]. The category of waste should be considered in context within the food chain, differentiating between waste and losses, concepts discussed in Section 2. These processing losses generate many by-products (approximately from 5 to $30 \%$ of the total raw material), such as the peel, bagasse, and pulp fractions in stages of size reduction (Table 6). These losses are significant biomass for its application in different industries due to its bioactive components and nutrients in producing new products [4]. 
Table 6. Food losses and waste (FLW) generated from the global processing of roots and tubers.

\begin{tabular}{|c|c|c|c|c|}
\hline Industrial Product & Process & By-Product & $\begin{array}{c}\text { Fraction of Raw Material } \\
\text { in Fresh Weight }(\%)\end{array}$ & References \\
\hline Frozen potato & Peeling & peel & $6-10$ & {$[146,147]$} \\
\hline Frozen yucca & Peeling & Peel & $3-5$ & {$[148,149]$} \\
\hline Cassava starch & $\begin{array}{l}\text { Peeling } \\
\text { Sifted }\end{array}$ & $\begin{array}{c}\text { Peel } \\
\text { Bagasse }\end{array}$ & $\begin{array}{c}3-5 \\
10\end{array}$ & [150] \\
\hline Potato starch & Peeling & Peel & $10-15$ & [97] \\
\hline Yam starch & Peeling & Peel & $4-5$ & [97] \\
\hline Cassava flour & $\begin{array}{l}\text { Peeling } \\
\text { Sifted }\end{array}$ & $\begin{array}{c}\text { Peel } \\
\text { Bagasse }\end{array}$ & $\begin{array}{c}3-5 \\
6\end{array}$ & [151] \\
\hline Potato chips and snacks & Peeling & Peel & $15-20$ & {$[152,153]$} \\
\hline Cassava chips and snacks & Peeling & Peel & $7-10$ & [65] \\
\hline
\end{tabular}

\subsubsection{Peels}

The processed root shells are between 2 and $15 \%$ of their total weight, usually generated in the peeling stage [143]. More than 11 million tons of peels are currently generated worldwide, where a small percentage are processed and used as feed animal ingredients due to the protein content. However, they are harmfully disposed of in landfills and water, mishandling these wastes [154]. These residues are essential due to their lignocellulosic characteristics (Table 7), which may vary according to their origin and the region where they are cultivated [155]. However, cassava peel contains linamarin and lotaustraline, toxic components found in a higher proportion in bitter cassava peels, the main variety processed in cassava starch manufacturing [156]. This component can be removed by heat treatments with an inactivation temperature of $75^{\circ} \mathrm{C}$ [157].

Table 7. Chemical composition of root and tuber peels.

\begin{tabular}{ccccccccc}
\hline Peels & Cellulose (\%) & $\begin{array}{c}\text { Hemicellulose } \\
\mathbf{( \% )}\end{array}$ & Lignin (\%) & Ash (\%) & Protein (\%) & Lipid (\%) & References \\
\hline Cassava (f.w.) & 37.90 & 23.90 & 7.50 & 4.50 & 4.73 & 0.19 & {$[158,159]$} \\
\hline Yam (f.w.) & - & - & - & 4.45 & 6.60 & 1.12 & {$[160]$} \\
\hline Potato (f.w.) & 15.00 & 39.00 & 10.00 & 6.34 & 8.00 & 2.60 & {$[161,162]$} \\
\hline
\end{tabular}

f.w. = fresh weight; d.w. = dry weight.

\subsubsection{Cassava Bagasse}

Bagasse is generated during the sieving or straining stage, where the pulp is separated from the fibrous material, constituting $10 \%$ of the processed cassava residue [150]. This residue contains a high percentage of water and starch residues because it is soaked in water in the starch separation stage. Under these conditions, bagasse presents a higher volume than the raw material represented by 60 to $90 \%$ of water and 10 to $30 \%$ of starch and fiber in dry weight [163]. Due to its fiber content, it provides lignocellulosic characteristics due to the cellulose (22\%), hemicellulose (35\%), and lignin contents (Table 8) [164].

Table 8. Bagasse composition from cassava processing.

\begin{tabular}{|c|c|c|c|c|c|c|c|}
\hline Bagasse & $\begin{array}{l}\text { Cellulose } \\
\text { (g/100 g) }\end{array}$ & $\begin{array}{l}\text { Hemicellulose } \\
\quad(\mathrm{g} / 100 \mathrm{~g})\end{array}$ & $\begin{array}{l}\text { Lignin } \\
\text { (g/100 g) }\end{array}$ & $\begin{array}{c}\text { Ash } \\
(\mathrm{g} / 100 \mathrm{~g})\end{array}$ & $\begin{array}{l}\text { Protein } \\
\text { (g/100 g) }\end{array}$ & $\begin{array}{l}\text { Lipid } \\
\text { (g/100 g) }\end{array}$ & Reference \\
\hline Cassava & 21.47 & 12.97 & 21.86 & 12.60 & 13.31 & 1.18 & [165] \\
\hline
\end{tabular}




\subsection{Production of the Cereal and Legume Industry}

Cereals are the leading staple food that provides the body with fuel and energy, thanks to the fact that they provide carbohydrates (between 50 and $70 \%$ ), proteins (between 30 and 35\%), lipids (2\%), and vitamins (20\%) [166]. On the other hand, legumes are an essential part of the diet due to their high protein content (up to $57 \%$ ), carbohydrates (between 40 and 50\%), fibers, and fats (between 8 and 15\%) [167] generating other consumption alternatives in addition to meat for human diet [168]. Cereals such as corn (Zea mays L.), wheat (Triticum aestivum), rice (Oryza sativa), cocoa (Theobroma cacao L.), sorghum (Sorghumvulgare), oats (Avena sativa), rye (Secale cereale L.), and barley (Hordeum vulgare) [169-171] have high economic importance supplying a large part of European, Asian, and American countries with a consumption of approximately 2500 million tons [172]. They are currently relevant, developing new processes to innovate commercially in different aspects [173]. Among the legumes with the most significant growth in production processes are beans (Phaseolus vulgaris), chickpeas (Cicer arietinum), peas (Pisum sativum), lentils (Lens culinaris), and pigeon peas (Cajanus cajan) [174,175], with a variety of precooked canned products, powders such as condiments and additives, instant soups, among others [176]. The production of cereals and legumes is led by China and India, respectively (Figure 8), being the foods with the highest processing after fruits and vegetables. According to statistics from the FAO, cereals' production constituted $73 \%$ and legumes $26.8 \%$ of this industry's total in 2018 [81].

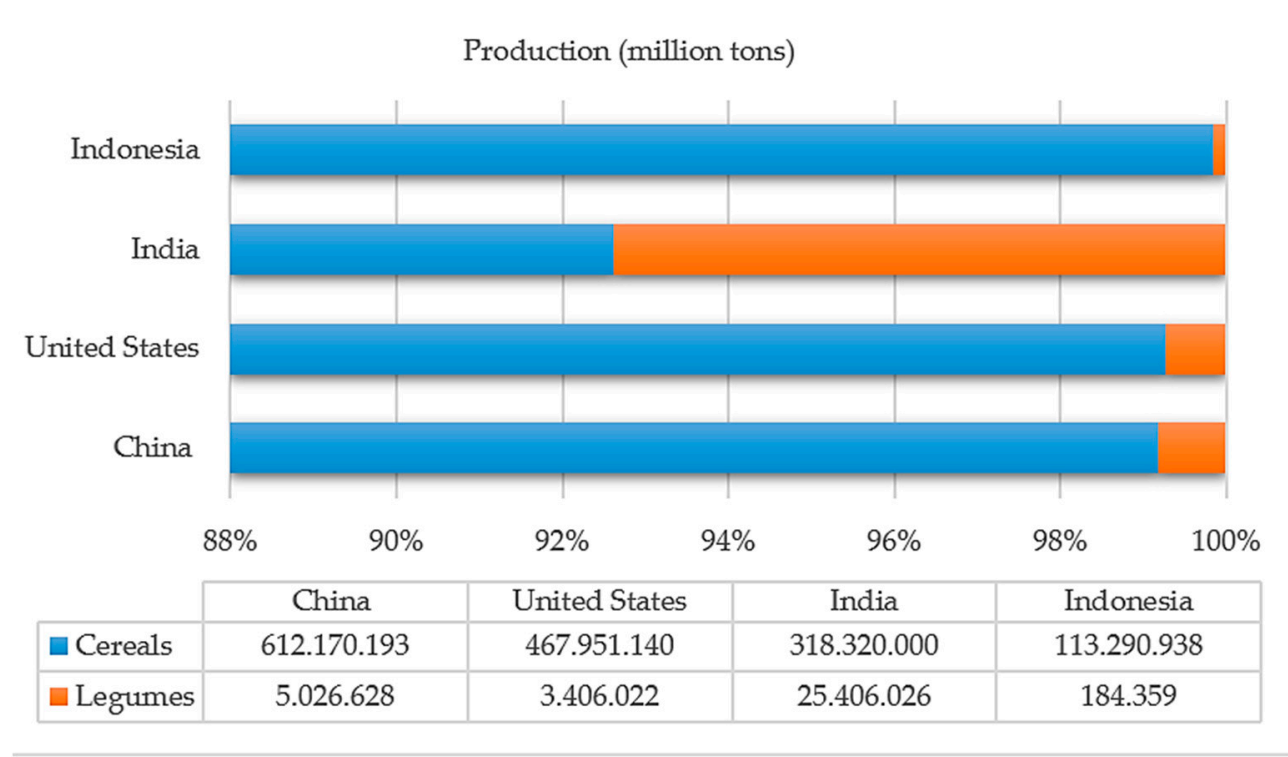

Figure 8. Leading countries in the production of cereals and legumes in 2018 [81].

In the industrial processing of cereals and legumes, food products such as flour, corn flakes and oats, and canned legumes are prepared, while edible oil is extracted from their seeds, such as soybean oil [177]. The cereal grains and legumes must go through specific stages for their conditioning according to the final product's physical characteristics, such as dehulling, grinding and sieving, and mechanical or solvent extraction of vegetable oils (Figure 9) [178]. These stages generate residues such as shells, cakes, or pellets from the oil extraction process and a fraction of raw material during the milling process [179]. The losses are used mostly for the production of energy and animal feed [180]. However, they have lignocellulosic characteristics and significant protein content that broaden their field of application to the food industry, such as the production of flours to prepare bread, cakes, and soups [179]. 


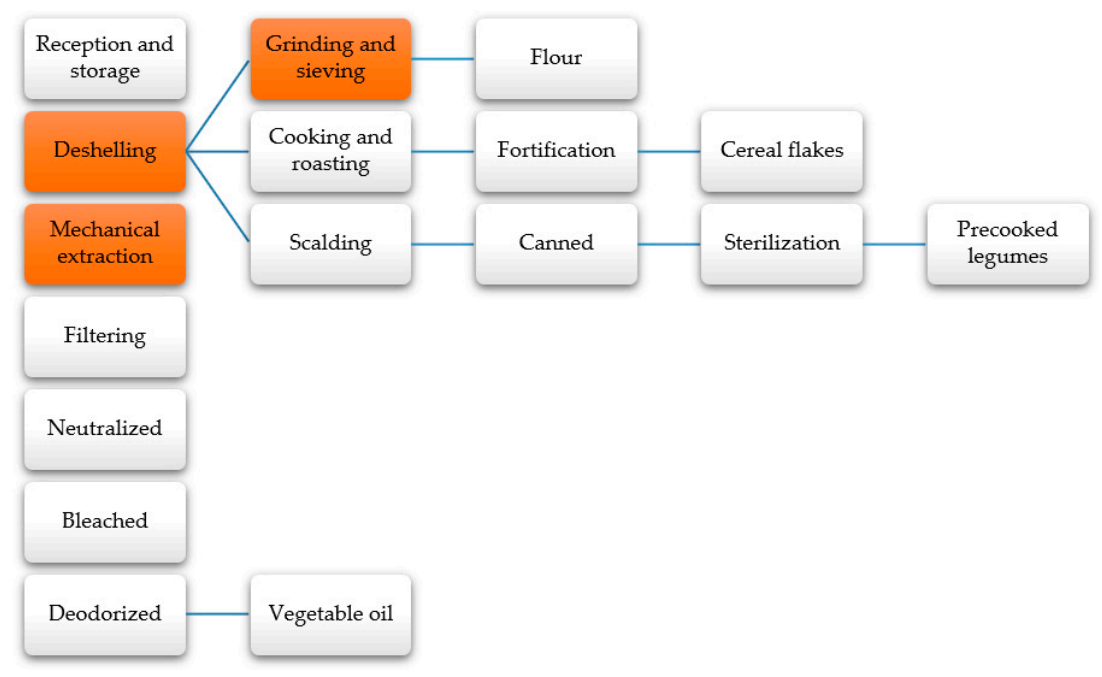

Figure 9. Industrial processing of cereals and legumes [181,182].

Cocoa is cultivated mainly in Europe, Asia, Africa, and America, with Africa as the largest producer ( $68 \%$ of the total world production), followed by the American continent, representing $15 \%$ of the world production [183]. The cocoa powder's industrial processing generates various products such as cocoa butter, cocoa liquor, and cocoa powder, making sweets and chocolate (with the highest production) [184]. The European continent is the largest chocolate producer with sales of $47 \%$ in the world market, followed by the United States, with $20 \%$ in sales [185].

In chocolate production, the cocoa is first conditioned (fermented and dried) before transportation to the production plant [184]. Within the processing of chocolate, there are stages (Figure 10) such as the roasting of the grain, where the primary purpose is to highlight the flavor, continuing with the shelling, where the shell is removed, then the seed enters the milling stage, for subsequent pressing and extraction of cocoa butter, which is finally conditioned for chocolate preparation [132]. The residues generated are found in the critical stage (cocoa cake or powder) and the deshelling (shell). The cocoa cake is used to make sweets and confectionery, while it has been used for animal feed to a lesser extent. Moreover, the shells are used to a lesser extent in animal feed, and in most cases, they are determined as waste taken to landfills [186].

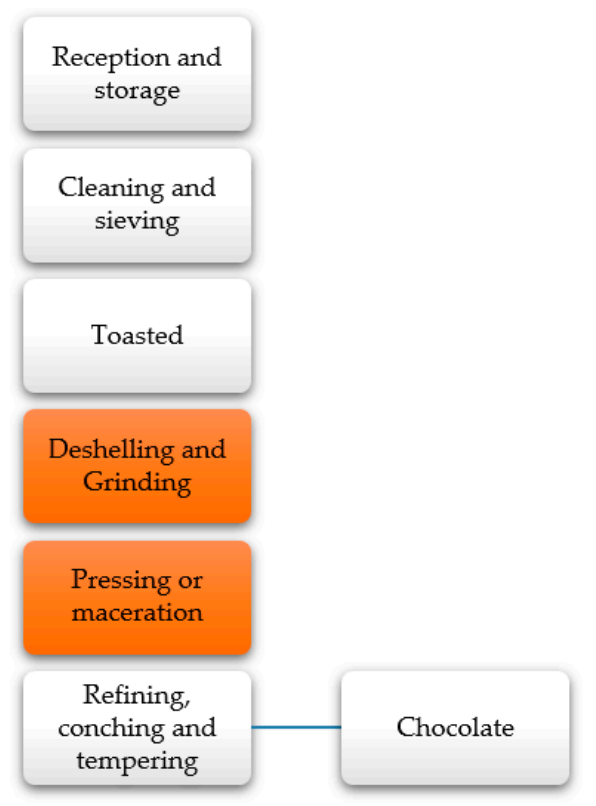

Figure 10. General diagram of cocoa processing [187]. 
The largest barley producers include the European Union, Russia, Canada, Ukraine, Australia, and the United States [188]. For the 2019-2020 crop year, the United States Department of Agriculture (USDA) estimated a global barley area of about 51.6 million hectares [189]. On average, $35 \%$ of barley is used as animal feed and $65 \%$ in beer manufacture [188]. In 2019, world beer production amounted to around 1.9 billion hectoliters, most of which were produced in China [189]. The barley grain undergoes processing for beer preparation, firstly malted, and then passes to the maceration and filtration for alcoholic fermentation. Finally, the maturation steps allow obtaining a high-quality beer (Figure 11) [190]. In the filtering stage, the malt bagasse is generated from processing as waste, and only a small fraction is used as animal feed [191]. In general, 20 to 21 kilos of brewing barley are needed to produce $100 \mathrm{~L}$ of beer. That means that from $100 \mathrm{~L}$ of beer produced, 5 to $6 \mathrm{~kg}$ of bagasse would be generated (20 to $25 \%$ of the barley's total weight). On a global scale, 1900 million hectoliters would generate 475 million bagasse bags, an alarming figure mainly limited to animal feed production [192].

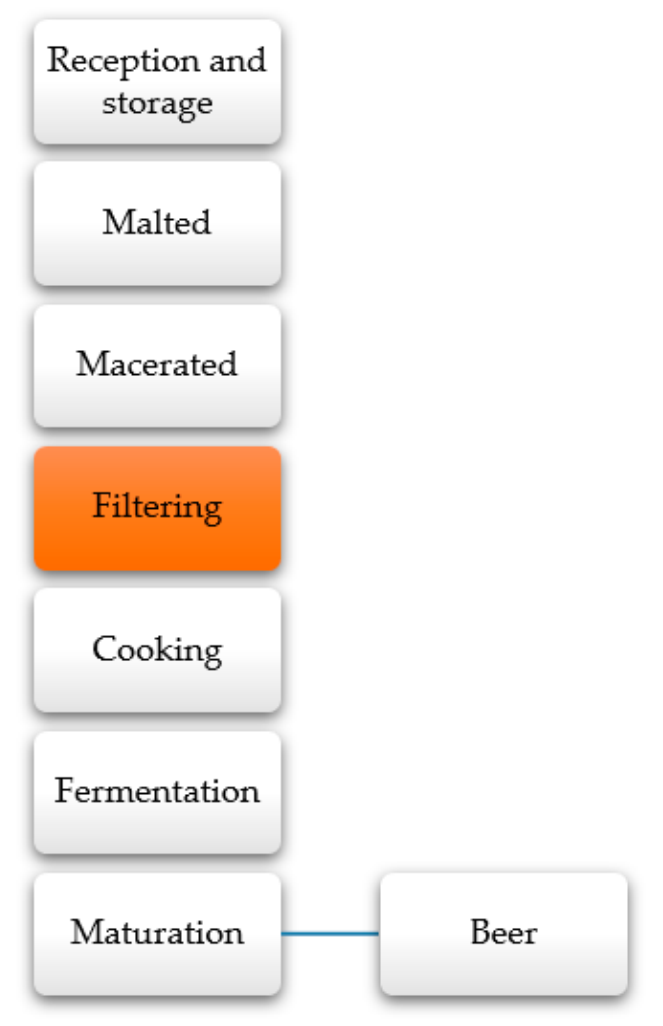

Figure 11. Industrial beer processing scheme [190].

\subsubsection{Food Losses and Waste (FLW) Generated from the Cereal and Legume Industry}

China is the world's largest cereal producer, followed by the United States, India, and Indonesia, with high consumption of processed foods such as croquettes, flours, and snacks [193]. However, they are also the main generators of FLW, especially in China and the United States [194]. In the processing of cereals and legumes, specific processes are required for optimal transformation, such as size reduction (if the final products are flours and canned goods), extraction of shells and functional compounds, pressing, drying, among others [195]. These stages also generate enormous losses (Table 9), with variations according to the raw material and the target product. Grain and legume shells, cake (cocoa or cereal), bagasse (beer), and pulp waste are among the essential wastes generated, which are generally discarded in landfills or water sources, increasing the pollution of the environment and wasting their chemical and nutritional potential [76]. 
Table 9. Food Losses and Waste (FLW) generated from the processing of cereals and legumes.

\begin{tabular}{|c|c|c|c|c|}
\hline Industrial Products & Process & By-Product & Raw Material Fraction (\%) & Reference \\
\hline Chocolate (f.w.) & Deshelling & Shell & $10-12$ & [196] \\
\hline \multirow{2}{*}{ Soy oil (d.w.) } & Deshelling & Shell & 8 & \multirow{2}{*}{ [197] } \\
\hline & Extraction & Cake & 60 & \\
\hline Beer (d.w.) & Filtering & Bagasse & $20-25$ & [192] \\
\hline Wheat flour (f.w.) & Deshelling & Shell & $15-20$ & [198] \\
\hline Corn flour (d.w.) & Deshelling & Shell & 6 & [199] \\
\hline Rice flour (f.w.) & Deshelling & Shell & 28 & [200] \\
\hline Canned beans (f.w.) & Deshelling & Shell & $6-8$ & [201] \\
\hline Canned peas (f.w.) & Deshelling & Shell & 10 & [201] \\
\hline
\end{tabular}

f.w. = fresh weight; d.w. = dry weight.

\subsubsection{Husks}

Husks residues are generated in the early stages of grain conditioning before the transformation in the dehulling and milling phase, where the coating is removed, and the endosperm is exposed [173]. In the wet milling process, it is possible to produce starch, sugar, syrup, or oil for human consumption from corn and, to a lesser extent, from sorghum [182]. Therefore, many of these cereals generate husk residues in large quantities, one of the most productive industries in the agri-food industry, such as chocolate, vegetable oils, and flours $[111,173,189]$. Among cereal husks' properties, the high composition of cellulose and hemicellulose are highlighted with a higher proportion in the husks of beans, cocoa, and corn (Table 10).

Table 10. Chemical composition of cereal and legume husks.

\begin{tabular}{|c|c|c|c|c|c|c|c|}
\hline Husk & Cellulose $(\%)$ & $\begin{array}{l}\text { Hemicellulose } \\
(\%)\end{array}$ & Lignin (\%) & Ash (\%) & Protein $(\%)$ & Lipid (\%) & References \\
\hline Cocoa (d.w.) & 35.40 & 37.00 & 14.70 & 12.30 & 16.70 & 36.9 & {$[158,202]$} \\
\hline Corn (d.w.) & 31.00 & 34.00 & 14.30 & 6.8 & - & - & [203] \\
\hline Wheat (d.w.) & 36.00 & 18.00 & 16.00 & - & 6.00 & 5.00 & [204] \\
\hline Soybean (d.w.) & 5.10 & 19.14 & 2.10 & 13.85 & 23.80 & 47.00 & {$[205,206]$} \\
\hline Rice (d.w.) & 40.00 & 21.00 & 22.00 & 16.00 & - & - & [207] \\
\hline Beans d.w.) & 50.25 & 1.23 & - & 3.51 & - & - & [208] \\
\hline Pea (d.w.) & 17.00 & 33.00 & 2.50 & - & 14.30 & - & [209] \\
\hline Oat (d.w.) & 17.20 & 33.10 & 25.40 & 6.00 & 1.70 & 0.50 & [210] \\
\hline
\end{tabular}

f.w. = fresh weight; d.w. = dry weight.

\subsubsection{Malt Bagasse}

The brewing industry generates bagasse during the pressing and filtering of the must due to barley's saccharification. It is a by-product rich in fiber (60-70\%) [190], carbohydrates, protein (between 20 and $60 \%$ on a dry basis, (Table 11), and a lignin content (4\%) [211]. The wet bagasse is susceptible to microbial contamination, being a compromising situation for its use in the food industry [190]. Different preservation methods should be used for moisture removals, such as freezing, drying, and preservatives that reduce moisture by up to $90 \%$ [212]. Because bagasse is a waste with high fiber content, it is viable for its use in confectionery, pastry, and other food products and its application to create biorefineries and animal feed [192,213]. 
Table 11. Composition of malt bagasse in beer processing.

\begin{tabular}{cccccccc}
\hline Bagasse & Fiber (\%) & Carbohydrate (\%) & Protein (\%) & Lipid (\%) & Ash (\%) & Reference \\
\hline Malt (dry weight) & 63.84 & 73.84 & 23.60 & 4.44 & 2.78 & {$[211]$} \\
\hline
\end{tabular}

\subsubsection{Waste Cake}

The edible vegetable oil industry generates solid waste, such as waste cakes, produced during the extraction process, either by pressing, with solvents or by centrifugation [190]. They are called cakes since, by pressing, a crushed bread shape is obtained. However, they are also presented in coarse flours or pellets [214]. These residues are generally used in animal feed due to their high protein content required in the animal diet [215]. The cake generated by soybean oil production contains a high percentage of proteins (Table 12). The discard cake is highly exported to the United States, Argentina, United Kingdom, and Mexico for animal feed and interest for its application in the food industry (for the production of flour, sausages, cereals, and tofu) [216].

Table 12. Composition of the waste cake from soybean oil processing.

\begin{tabular}{cccccccc}
\hline Cake & Protein (\%) & Fiber (\%) & Ash (\%) & Calcium (\%) & Phosphorus (\%) & Reference \\
\hline Soybean (dry weight) & 47.50 & 5.10 & 6.40 & 0.13 & 0.64 & {$[197]$} \\
\hline
\end{tabular}

\section{Potential of Food Losses and Waste as a Raw Material in the Industry}

\subsection{Food Industry}

One of the significant waste producer industries is the food industry, accounting for $70 \%$ of agricultural waste in the world [217]. Due to this problem, the generation of new waste recovery mechanisms is of great interest to the care of resources and the environment [218]. In the search to introduce these residues to food production, analyzes have been carried out against the components that can be exploited within the residual biomass [219]. The term by-product implies reusing waste as raw material, source, or ingredient, integrating it into the production process, turning a cost into a benefit [22]. Likewise, to reduce waste, action must be taken from the source, reducing the excessive amount of raw material used in industries and implementing monocultures through the formulation and execution of comprehensive management plans [220]. That is why the investigations of extraction, characterization, and application of residues from the food industry are of great interest for their use as by-products, giving alternatives on the excellent management of residues and the minimization of the indiscriminate use of natural resources contributing to a transition from the linear economy to a circular economy [221].

\subsubsection{Flours}

Flours are physically characterized as fine powders obtained from the cereal grinding or starch present in food. Among the most common are wheat, corn, sorghum, rye, and oat flour. It is considered one of the main foods in the human diet [222]. In recent years, the world's flour production has been characterized by its fortification by adding compounds and vitamins, supplementing the required daily nutritional balance [223]. The seeds, peels, and fruit pomace generated in the processing of food products present nutritional and sensory components, which are of great interest for preparing functional foods, thus reducing the addition of components in flours to obtain food products [224]. Consequently, studies have been carried out for the partial substitution of wheat, oat, and cornflour for peel, seed, and fruit pomace flour to prepare functional foods (Table 13), which have shown a favorable impact on the products obtained, increasing the nutritional content and antioxidant activity (due to the increase in phenolic content), without altering the physical and organoleptic properties. 
Table 13. Applications of flours obtained from agri-food by-products in functional foods preparation.

\begin{tabular}{|c|c|c|c|c|}
\hline By-Product & Application & Added Amount (\%) & Effect of By-Product Flours on Functional Foods & Reference \\
\hline Seed, pomace, and grape peel & Baked goods and pasta & $\begin{array}{l}\text { 2, } 4 \text {, and } 6 \text { (seeds); } 3,6 \\
\text { and } 9 \text { (pomace); } 2,5, \\
\text { and } 10 \text { (pomace), respectively }\end{array}$ & $\begin{array}{l}\text { Increase of functional ingredients in the bakery, pastry, and } \\
\text { pasta industries without damaging the } \\
\text { quality of the products }\end{array}$ & [225] \\
\hline Pigeon pea cotyledon & Biscuit & $\begin{array}{l}95,90, \text { and } 85 \text { of wheat flour; } 5,10, \\
\text { and } 15 \text { pigeon pea flour }\end{array}$ & $\begin{array}{l}\text { The protein content of the cookies enriched with pigeon pea } \\
\text { cotyledon } 1.4 \text { times and a significant increase in fiber content }\end{array}$ & [226] \\
\hline $\begin{array}{l}\text { Grape peel, seeds, } \\
\text { and remains of the pulp }\end{array}$ & Biscuit & $\begin{array}{l}30 \text { and } 40 \text { replacement } \\
\text { with wheat flour }\end{array}$ & $\begin{array}{c}\text { The flour presented physicochemical characteristics within } \\
\text { the nutritional standards, with an acceptance of } \\
92.6 \% \text { of the consumers evaluated }\end{array}$ & [227] \\
\hline Grape pomace & Biscuit & $\begin{array}{l}10,20,30,40 \text {, and } 50 \text { replacement of } \\
\text { grape pomace flour } \\
\text { with wheat flour }\end{array}$ & $\begin{array}{l}\text { The protein, fiber, and ash content increased considerably in } \\
\text { the product, with consumer acceptability of } 100 \%\end{array}$ & [228] \\
\hline $\begin{array}{l}\text { Pomegranate, grape, and } \\
\text { rosehip seeds }\end{array}$ & Turkish noodles & $\begin{array}{l}10,20 \text {, and } 30 \text { inclusion of grape } \\
\text { pomegranate and } \\
\text { rosehip, respectively }\end{array}$ & $\begin{array}{c}\text { The addition of } 10 \% \text { of grape, pomegranate, and rosehip } \\
\text { seeds increased the antioxidant activity of the product } \\
\text { between } 5.7 \text { and } 8.4 \text { times }\end{array}$ & [229] \\
\hline $\begin{array}{l}\text { Apple pomace and } \\
\text { sugarcane bagasse }\end{array}$ & $\begin{array}{l}\text { Corn extrudates } \\
\text { (high fiber croquettes) }\end{array}$ & $15-30$ cornmeal substitution & $\begin{array}{c}\text { The inclusion of apple pomace and sugarcane bagasse } \\
\text { showed the potential to produce extrudates with significant } \\
\text { expansion, with relatively lower energy inputs } \\
\text { and high fiber content }\end{array}$ & [230] \\
\hline Olive pomace & Oat and rice extrudates & $\begin{array}{l}5 \text { and } 10 \text { substitutions of } \\
\text { rice flour and oats }\end{array}$ & $\begin{array}{l}\text { Favorable impact on the physical characteristics of the } \\
\text { extruded product for the base of rice flour and oats. High } \\
\text { content of fiber, protein, and polyphenols through the } \\
\text { incorporation of olive pomace }\end{array}$ & [231] \\
\hline Apple pomace & Sorghum and corn extrudates & $\begin{array}{l}\text { 10, 20, and } 30 \text { substitutions with } \\
\text { sorghum and cornflour }\end{array}$ & $\begin{array}{l}\text { Extruded products with better phenolic content, antioxidant } \\
\text { activity, textural, and functional properties with greater } \\
\text { inclusion of apple pomace were obtained }\end{array}$ & [232] \\
\hline Pineapple peels & Cereal bars & $\begin{array}{l}3,6 \text {, and } 9 \text { inclusion of } \\
\text { pineapple peel flour }\end{array}$ & $\begin{array}{l}\text { Adding up to } 6 \% \text { pineapple peel flour to cereal bars did not } \\
\text { alter sensory acceptance and increased fiber content }\end{array}$ & [233] \\
\hline Grape seeds & Cereals, pancakes, and noodles & $\begin{array}{l}\text { Substitution of } 25 \text { and } 30 \text { of grape } \\
\text { seed flour in pancakes, } 20 \text { in } \\
\text { noodles, and } 5 \text { in cereal bars }\end{array}$ & $\begin{array}{l}\text { The cereal bars, pancakes, and noodles had a high } \\
\text { acceptance by the consumer }\end{array}$ & [234] \\
\hline Watermelon seeds & Biscuit & $\begin{array}{l}\text { Substitution with } 5-10 \text { of } \\
\text { watermelon seed flour in Biscuits }\end{array}$ & $\begin{array}{l}\text { Watermelon in concentrations of } 5-7.5 \% \text { in cookies improves } \\
\text { quality and increases the protein content }\end{array}$ & [235] \\
\hline
\end{tabular}




\subsubsection{Colorants}

The food colorants market is currently valued at USD 5 billion in 2020 and is estimated to grow at USD 6.8 billion by 2025, with a compound growth rate (CAGR) of 5.4\% [236], where the largest market is in the European continent, followed by Asia and North America [237]. The industry of colorants is classified into two categories according to their origin. Synthetic colorants are obtained from petroleum derivatives [238], and natural colorants, obtained from fruit extracts and vegetables, can provide antioxidant capacities and increase nutritional food value [239]. Natural colorants are considered safer for food than synthetic colorants because of consumers' health and environmental concerns [240]. According to a study conducted by the Clean Label Alliance, $75 \%$ of consumers are willing to pay a high price for clean label products (minimally processed products with the least amount of synthetic additives) [236]. However, Food safety would be put at risk by allocating raw material for food for industrial use [241].

Among the natural colorants available in food by-products are betanin, lutein, riboflavin, and anthocyanins, mainly found in fruit peels' residues [238]. Studies have been carried out at laboratory scale and very few at pilot scale (Table 14) to use residues to extract colorants and their application in the food industry as additives and as a source of nutrients.

Table 14. Studies carried out in the extraction of colorants from agri-food by-products.

\begin{tabular}{|c|c|c|c|c|c|}
\hline Pigment & By-Product & Extraction Method & Production Scale & $\begin{array}{l}\text { Applications in } \\
\text { Food Products }\end{array}$ & Reference \\
\hline Cyanidin & Ficus carica L. peel & $\begin{array}{l}\text { Heat, microwave, } \\
\text { and ultrasound }\end{array}$ & Laboratory scale & $\begin{array}{l}\text { Additive and } \\
\text { natural coloring in } \\
\text { pastry and } \\
\text { confectionery }\end{array}$ & [242] \\
\hline $\begin{array}{l}\text { Cyanidin } \\
\text { 3-glucoside }\end{array}$ & Coffee exocarp & $\begin{array}{l}\text { Solvent Extraction (SC) } \\
\text { and Solid Solvent (SSR) }\end{array}$ & Laboratory scale & $\begin{array}{l}\text { Natural coloring } \\
\text { applied to } \\
\text { French meringue }\end{array}$ & [243] \\
\hline $\begin{array}{l}\text { Cyanidin } \\
\text { 3-glucoside }\end{array}$ & $\begin{array}{l}\text { The by-product of } \\
\text { the mulberry } \\
\text { industry }\end{array}$ & $\begin{array}{l}\text { By-product mixture with } \\
\text { water } 1: 3(w / v) \text { stirred } \\
\text { for eight hours in the } \\
\text { dark, filtered through a } \\
\text { sieve, and evaporated to } \\
1 / 3 \text { of the initial volume }\end{array}$ & Laboratory scale & $\begin{array}{c}\text { Additive and } \\
\text { natural coloring }\end{array}$ & [244] \\
\hline $\begin{array}{l}\text { Quercetin, } \\
\text { Cyanidin 3-O- } \\
\text { glucoside }\end{array}$ & $\begin{array}{l}\text { Solid waste and } \\
\text { onion leaves }\end{array}$ & $\begin{array}{l}\text { Extraction by ecological } \\
\text { solvents, such as water } \\
\text { and glycerol. } \\
\text { 2-Hydroxypropyl- } \beta \text { - } \\
\text { cyclodextrin was also } \\
\text { used as a co-solvent to } \\
\text { increase the } \\
\text { extraction yield. }\end{array}$ & Pilot-scale & $\begin{array}{l}\text { Natural coloring } \\
\text { applied to yogurts, } \\
\text { providing } \\
\text { antioxidant } \\
\text { properties }\end{array}$ & [245] \\
\hline$\beta$-carotene & $\begin{array}{l}\text { Tomato peel } \\
\text { and seed }\end{array}$ & $\begin{array}{l}\text { Ultrasound extraction } \\
\text { and application } \\
\text { in biofilms }\end{array}$ & Laboratory scale & $\begin{array}{l}\text { Edible biofilm } \\
\text { coloring }\end{array}$ & [246] \\
\hline $\begin{array}{l}\text { Bethany and } \\
\text { iso-betanin }\end{array}$ & $\begin{array}{l}\text { Peel and waste } \\
\text { pulp of red } \\
\text { prickly pear }\end{array}$ & $\begin{array}{l}\text { Pulsed electric field } \\
\text { and ultrasound }\end{array}$ & Pilot-scale & $\begin{array}{l}\text { Natural dyes. } \\
\text { Protection against } \\
\text { low-density } \\
\text { lipoprotein (LDL) } \\
\text { oxidative } \\
\text { modifications }\end{array}$ & [240] \\
\hline
\end{tabular}


Table 14. Cont.

\begin{tabular}{|c|c|c|c|c|c|}
\hline Pigment & By-Product & Extraction Method & Production Scale & $\begin{array}{l}\text { Applications in } \\
\text { Food Products }\end{array}$ & Reference \\
\hline $\begin{array}{c}\text { Lycopene, } \\
\text { phytoene, } \\
\text { phytofluene, and } \\
\beta \text {-carotene }\end{array}$ & Tomato peel & $\begin{array}{c}\text { Extraction using organic } \\
\text { solvents (ethanol } \\
\text { and acetone) }\end{array}$ & Laboratory scale & $\begin{array}{l}\text { Natural colors in } \\
\text { sunflower oil } \\
\text { and spaghetti }\end{array}$ & [247] \\
\hline $\begin{array}{c}\beta \text {-carotene, } \\
\gamma \text {-carotene, and } \\
\delta \text {-carotene }\end{array}$ & $\begin{array}{c}\text { Astrocaryum } \\
\text { vulgare } \\
\text { and Bactris gasipaes } \\
\text { peel }\end{array}$ & $\begin{array}{l}\text { Extraction using organic } \\
\text { solvents (ethanol } \\
\text { and acetone) }\end{array}$ & Laboratory scale & $\begin{array}{l}\text { Natural coloring, } \\
\text { in addition to } \\
\text { being a source of } \\
\text { vitamin } A\end{array}$ & [248] \\
\hline $\begin{array}{l}\text { Lutein and } \\
\text { zeaxanthin }\end{array}$ & Orange peels & $\begin{array}{c}\text { Use of the fungi } \\
\text { Monascus purpureus and } \\
\text { Penicillium purpurogenum } \\
\text { by fermentation in } \\
\text { solid-state (SSF) and } \\
\text { semi-solid (ST) and } \\
\text { aqueous solutions of } \\
\text { ethanol } 70 \% v / v \text { and } \\
\text { isopropanol } 95 \% v / v\end{array}$ & Laboratory scale & $\begin{array}{l}\text { Natural coloring } \\
\text { in pastry }\end{array}$ & [249] \\
\hline $\begin{array}{l}\text { Lycopene, } \\
\text { phytoene, } \\
\text { phytofluene, } \\
\beta \text {-carotene, } \\
\text { cis-lycopene, } \\
\text { and lutein }\end{array}$ & Tomato peel & $\begin{array}{l}\text { Dried at } 40{ }^{\circ} \mathrm{C} \text {, ground } \\
\text { and passed through } 0.15 \\
\mathrm{~mm} \text {, using ethanol as } \\
\text { solvent and } \\
\text { acetone } / \text { hexane } \\
(50: 50 \mathrm{v} / \mathrm{v}) \text {. } \\
\text { The method described } \\
\text { by Hackett et al. [250] }\end{array}$ & Laboratory scale & $\begin{array}{l}\text { Natural coloring } \\
\text { and antioxidant in } \\
\text { ice cream }\end{array}$ & [251] \\
\hline
\end{tabular}

\subsubsection{Enzymes}

Enzymes are of great importance in the industrial sector, as they allow sustainable development by reducing the chemical load of processes, eliminating toxic substances, and reducing pollutants [252]. Currently, the industrial enzymes market encompasses USD 5.9 billion, with a USD 8.7 billion projection in 2026 and a CAGR of 6.5\% [253]. Among the most popular enzymes in the industry are lipases, carbohydrases, proteases, and polymerases applied in beverages and processed meat, dairy, fruits, and vegetables [253]. Among the leading countries in the enzyme industry market is the United States, China, the United Kingdom, Australia, Brazil, and Argentina [254]. The food industry produces large amounts of processing waste annually, most of which are lignocellulosic, containing a wide variety of enzymes considered critical raw materials in production and processes [255]. For example, bromelain extracted from pineapple can improve food digestion and soften beef to transform into value-added products in the market [256]. Lipases have various applications as food additives in the modification of taste, the synthesis of esters with an enjoyable antioxidant activity, hydrolysis of fats to produce detergents, wastewater treatment, and lipids removal in the cosmetic and pharmaceutical industry [257]. In this way, studies have been carried out for the enzyme extraction from agri-food waste (Table 15). 
Table 15. Extraction of enzymes from agri-food by-products.

\begin{tabular}{|c|c|c|c|c|}
\hline Enzyme & By-Product & Method & Result & References \\
\hline \multirow{5}{*}{ Bromelain } & Pineapple peel & $\begin{array}{l}\text { An aqueous biphasic } \\
\text { system consisting of } \\
\text { polyethylene glycol (PEG) } \\
\text { and polyacrylic acid }\end{array}$ & $\begin{array}{l}\text { Bromelain extraction achieved } \\
\text { a yield of } 335.27 \% \text { with a } \\
\text { purification factor of } \\
25.78 \text { in PEG }\end{array}$ & [256] \\
\hline & Pineapple stems & $\begin{array}{l}\text { Aqueous two-phase } \\
\text { micellar systems with ionic } \\
\text { liquids as co-surfactants }\end{array}$ & $\begin{array}{l}\text { A high bromelain recovery } \\
(90 \%) \text { was found for the low } \\
\text { micelle phase for all systems }\end{array}$ & [258] \\
\hline & Pineapple peel & $\begin{array}{l}\text { Gemini surfactant-based } \\
\text { reverse micelle }\end{array}$ & $\begin{array}{l}\text { Activity recovery, purification } \\
\text { fold, and protein extraction } \\
\text { efficiency were } 160 \text { to } 163 \%, 2.7 \\
\text { to } 3.3 \text {, and } 59 \% \text {, respectively }\end{array}$ & {$[259,260]$} \\
\hline & $\begin{array}{l}\text { Pineapple stems } \\
\text { and skins }\end{array}$ & $\begin{array}{l}\text { Precipitation with } \\
\text { carrageenan using } \\
\text { a factorial } \\
\text { experimental design }\end{array}$ & $\begin{array}{l}\text { High recovery yield } 80-90 \% \text { of } \\
\text { active bromelain for both } \\
\text { (stems and peels), making it } \\
\text { possible to obtain } \\
\text { approximately } 0.3 \mathrm{~g} \text { of } \\
\text { bromelain from } 100 \mathrm{~g} \text { of } \\
\text { pineapple by-products }\end{array}$ & [261] \\
\hline & $\begin{array}{l}\text { Peel, pulp residues, } \\
\text { and pineapple core }\end{array}$ & $\begin{array}{l}\text { Extraction with ethanolic } \\
\text { polyphenol from } \\
\text { cashew leaves }\end{array}$ & $\begin{array}{l}\text { Solids were obtained from } \\
\text { pineapple waste with the } \\
\text { following protease activities: } \\
5343 \text { CDU/g (core), } \\
5147 \text { CDU/g (shell), and } \\
5732 \text { CDU/g (pulp) }\end{array}$ & [124] \\
\hline \multirow{4}{*}{ Lipases } & $\begin{array}{l}\text { Bagasse and shell of } \\
\text { Pear var. Hamlin, } \\
\text { Valencia, and Natal }\end{array}$ & $\begin{array}{l}\text { Emulsified olive oil and on } \\
\text { p-nitrophenyl substrates }\end{array}$ & $\begin{array}{l}\text { The bagasse and peel lipases } \\
\text { from different orange varieties } \\
\text { were obtained at an optimum } \\
\text { pH between } 6.0-8.0 \text { and an } \\
\text { optimum range temperature } \\
\text { between } 30 \text { to } 60^{\circ} \mathrm{C}\end{array}$ & [262] \\
\hline & $\begin{array}{l}\text { Industrial waste from } \\
\text { palm oil }\end{array}$ & $\begin{array}{l}\text { Use of selected strain of } \\
\text { Aspergillus niger grown in } \\
\text { solid-state (SSF) } \\
\text { and submerged } \\
\text { fermentation (SMF) }\end{array}$ & $\begin{array}{l}\text { Lipase activity levels of up to } \\
15.41 \mathrm{UI} / \mathrm{mL} \text { were reached in } \\
\text { the palm oil extract by SSF }\end{array}$ & [263] \\
\hline & Olive oil cake & $\begin{array}{l}\text { Use of Candida utilis in } \\
\text { solid-state fermentation }\end{array}$ & $\begin{array}{c}\text { An alkaline substrate } \\
\text { treatment appeared to be } \\
\text { effective, leading to } 39 \% \\
\text { increases in lipase production }\end{array}$ & [264] \\
\hline & Mango seeds and peel & $\begin{array}{l}\text { Use of Yarrowia lipolytica in } \\
\text { submerged fermentation }\end{array}$ & $\begin{array}{l}\text { The highest lipase activity } \\
\text { observed was } 3500 \mathrm{UI} / \mathrm{L} \text { of the } \\
\text { solid residue }\end{array}$ & [265] \\
\hline Amylases & Mango seeds & $\begin{array}{l}\text { Use of Aspergillus niger } \\
\text { isolated }\end{array}$ & $\begin{array}{l}\text { The maximum } \alpha \text {-amylase } \\
\text { activity was obtained }\end{array}$ & [266] \\
\hline
\end{tabular}

\subsection{Cosmetic Industry}

Cosmetics comprise a large industry for the care, protection, and improvement of the skin. This industry generates more than 500,000 million dollars, and it is estimated that by 2023 it will increase by $57 \%$ due to the large consumption of these products by new generations $[267,268]$. Among the countries with the highest cosmetics consumption, the United States is the leader with approximately 7000 million dollars, followed by Japan, Russia, and the United Kingdom [95]. Cosmetics are classified according to their functionality as hygienic (deodorants, cleansing foams, soaps), decorative (hair dyes, 
eye, and face makeup), corrective (lighteners, epilators, depigmented), and protective (sunscreen, moisturizers, lubricants) [268]. Each product is composed of a base substance, an active component, and the raw material or main ingredient used. Therefore, for the formulation of cosmetics, chemical compounds such as parabens and formaldehyde are used as preservatives. However, there is some uncertainty in using these components to affect metabolism, inducing a public concern for their massive application [269]. The use of these compounds has been reduced, incorporating cosmetic products with natural ingredients of fruits and cereals such as rice, orange, and oat bran. The process includes extracting their bioactive compounds and applying them in formulations as moisturizers and antioxidants for skincare [270].

\section{Antioxidants}

Antioxidants scavenge free radicals and prevent oxidation in body cells [271]. Cosmetics are mainly composed of antioxidants for their properties to reduce cell aging, applied in creams, powders, and oils for the skin [272]. One of the antioxidants' properties with the most significant use on the market is the increase in skin protection against $\mathrm{UV}$ rays when added to creams with sunscreen, preventing the destruction of collagen and photoaging [273]. Antioxidants such as phenolic compounds, also defined as polyphenols, are derived from plants' secondary metabolism [274]. They are commonly found in foods such as vegetables, fruits, and legumes consumed daily by humans, present in the pulp and seeds, skins, and pomace [39]. For instance, the extraction and application of phenolic compounds from the loss and waste of food have been of great interest due to their antioxidant capacity and to avoid the massive use of food to preserve food safety worldwide. [267]. For that reason, seeds and peels are considered antioxidant sources and are incorporated in the formulation of sunscreens (Table 16).

Table 16. Agri-food by-products as a photoprotective source in the formulation of sunscreens.

\begin{tabular}{|c|c|c|c|}
\hline By-Product & Study & Result & Reference \\
\hline Passion fruit seed & $\begin{array}{l}\text { Formulation of sunscreen as } \\
\text { foundation and } \\
\text { correction makeup }\end{array}$ & $\begin{array}{l}\text { The } 3 \% \text { passion fruit polar extract correctors had } \\
\text { a sun protection factor (SPF) of } 18.09 \pm 1.48 \text { and } \\
18.60 \pm 1.21 . \text { Did not cause skin irritation when } \\
\text { evaluated in human volunteers }\end{array}$ & [275] \\
\hline Grapeseed & $\begin{array}{l}\text { Evaluation of the protective } \\
\text { effects of grape seed on } \\
\text { fibroblasts irradiated } \\
\text { with UV light }\end{array}$ & $\begin{array}{l}\text { Grape seed increased cell viability and } \\
\text { effectively protected fibroblasts from UV } \\
\text { damage, also improving UV filter absorbency } \\
\text { and overall formulation efficacy }\end{array}$ & [267] \\
\hline Oat shell and walnut & $\begin{array}{l}\text { Determination of functional } \\
\text { properties such as antioxidant } \\
\text { power and UV absorption } \\
\text { capacity of lignans extracted } \\
\text { from by-products }\end{array}$ & $\begin{array}{l}\text { The extracted lignans showed adequate } \\
\text { protection against UV radiation, } \\
\text { a property of great interest to block the } \\
\text { entire ultraviolet spectrum }\end{array}$ & [276] \\
\hline Industrial coffee waste & $\begin{array}{l}\text { Biological effects of the } \\
\text { by-product in the } \\
\text { development of a new } \\
\text { generation of solar filters }\end{array}$ & $\begin{array}{l}\text { The emulsion containing } 35 \%(w / w) \text { of the coffee } \\
\text { fraction showed improvements in water } \\
\text { performance with a broad spectrum of sun } \\
\text { protection (SPF) compared to an emulsion } \\
\text { containing } 35 \%(w / w) \text { of green coffee that } \\
\text { improved the SPF in physical sunscreens }\end{array}$ & [277] \\
\hline
\end{tabular}


Table 16. Cont.

\begin{tabular}{|c|c|c|c|}
\hline By-Product & Study & Result & Reference \\
\hline $\begin{array}{l}\text { Waste from the } \\
\text { guava industry }\end{array}$ & $\begin{array}{l}\text { Formulation of a cosmetic } \\
\text { product as a sunscreen }\end{array}$ & $\begin{array}{l}\text { The polar extract showed synergy with the UV } \\
\text { chemical filter (Ethylhexyl methoxycinnamate), } \\
\text { enhancing the sun protection factor by } 17.99 \%\end{array}$ & [278] \\
\hline Grape seeds & $\begin{array}{l}\text { By-product effect and its UV } \\
\text { and visible light } \\
\text { protection capacity }\end{array}$ & $\begin{array}{l}\text { The by-product showed the ability to absorb a } \\
\text { wide range of the solar spectrum, including } \\
\text { ultraviolet and blue light. At a concentration of } \\
100 \mu \mathrm{g} / \mathrm{mL} \text {, it significantly inhibited nitrous } \\
\text { oxide production in RAW } 264.7 \text { cells (commonly } \\
\text { used model of mouse macrophages for the study } \\
\text { of cellular responses) }\end{array}$ & [279] \\
\hline Rambutan skin & $\begin{array}{l}\text { Develop a sunscreen based on } \\
\text { rambutan skin polar extracts }\end{array}$ & $\begin{array}{c}\text { The by-product can synergistically increase the } \\
\text { sun protection factor (SPF) values of synthetic } \\
\text { organic sunscreens and lower costs in a } \\
\text { sunscreen formulation }\end{array}$ & [280] \\
\hline $\begin{array}{l}\text { Shells and seeds } \\
\text { Amazonian fruits }\end{array}$ & $\begin{array}{l}\text { Determine the protection } \\
\text { capacity of polar seed extracts } \\
\text { against UV light }\end{array}$ & $\begin{array}{l}\text { The polar extracts showed high capacity, } \\
\text { especially Caryocar villosum, Garcinia madruno, } \\
\text { and Bertholletia excelsa with UV absorption peaks, } \\
\text { and piquiá, bacurizinho, and açaí seeds } \\
\text { (Euterpe oleracea and E. precatoria) }\end{array}$ & [281] \\
\hline
\end{tabular}

\subsection{Pharmaceutical Industry}

There has been a considerable increase in the manufacture of synthetic antimicrobial compounds against microorganisms that cause respiratory diseases, infections, or conditions in humans [282]. Worldwide, the pharmaceutical sector reached a CAGR of $8.8 \%$, exceeding $\$ 1$ billion in 2017 [283]. According to a study carried out by IQVIA, the sector should experience market growth between 3 to $6 \%$ over the next five years, exceeding 1.5 trillion dollars in 2023 [284]. However, the synthetic compounds in pharmaceutical products contain contraindications and side effects that can lead to the appearance of new health alterations and create resistance in bacterial strains [285]. Kardan et al. [286] evaluated the gene expression of the efflux pump (a mechanism that evaluates the resistance of microorganisms in drugs) in 31 clinical isolates of strains of Mycobacterium tuberculosis, determining gene mutations in $66.6 \%$ of the isolates (overexpression of the pump flow). Due to this, medicinal research against new alternatives in the preparation of drugs that do not affect health in the background has been of great interest in recent years, emphasizing bioactive compounds from plants, fruits, and functional foods [287]. The food industry generates many by-products worldwide that are discarded from the food transformation process that have a high content of compounds required as a raw material in the manufacture of medicines [288]. For this reason, research on the use of citrus fruit by-products has had a significant boom in recent years due to its antiviral, anti-inflammatory, antibacterial, and antifungal properties.

The bioactive compounds present are useful to produce medicines applied in the treatment of acute and chronic diseases. These residues are usually sources of phytochemical compounds and essential nutrients for developing and recovering the human body $[289,290]$. The extraction of these compounds from by-products is carried out by several routes [291]. In the case of phenolic extracts such as hesperidin, nobiletin, and tangeretin, there are currently ecological techniques such as hydroalcoholic extraction [292], which is $90 \%$ efficient both on a laboratory scale and on a pilot scale, and hydrodistillation applied mostly to the shells of citrus which provides $17 \%$ more performance than conventional methods [292,293]. In the same way, controlled hydrodynamic cavitation is the route with the highest performance overcoming acoustic cavitation to pilot scale for most applications, including natural products extraction [294,295]. Ultrasonic extraction with organic solvents offers advantages with much faster extraction rates than the medium 
and low energy consumption in conjunction with the MTT assay method that reflects the cellular viability due to the antimicrobial capacity of bioactive compounds [296].

\subsubsection{Antibacterial and Anticancer}

Agri-food waste can increase the bioavailability of a large number of drugs as they are an excellent source of nutrients and phytochemical compounds capable of contributing to a healthy diet [297]. They are a good source of organic acids, sugars, and phenolic compounds such as flavonoids and anthocyanins, which have therapeutic applications due to their antibacterial, antifungal, anti-inflammatory, immunomodulatory activities under various conditions and an antioxidant potential against free radicals [298].

From the point of view of the recovery of residues such as peels, pomace, and seeds, commonly generated by the industries producing juices and other food products [231], the various investigations carried out on the bioactive compounds in these residues (Table 17) have been of great importance.

Table 17. Studies for the efficiency of fruit and vegetable by-products as antibacterial, anti-inflammatory, and anticancer agents.

\begin{tabular}{|c|c|c|c|}
\hline By-Product & Study & Result & Reference \\
\hline $\begin{array}{l}\text { Orange peel } \\
\text { (Citrus sinensis) }\end{array}$ & $\begin{array}{l}\text { Phenolic extracts of the orange peel } \\
\text { against oxidative stress in primary } \\
\text { human colon tumor (Caco-2) and } \\
\text { metastatic cell lines } \\
\text { (LoVo and LoVo/ADR) }\end{array}$ & $\begin{array}{l}\text { Orange peels showed antioxidant properties } \\
\text { by inhibiting the activities of total matrix } \\
\text { metalloproteinases (MMP), preventing the } \\
\text { progression of cancer and the } \\
\text { tumor cell metastasizing }\end{array}$ & [289] \\
\hline $\begin{array}{l}\text { Orange peel } \\
\text { (Citrus sinensis) }\end{array}$ & $\begin{array}{l}\text { Matrix metalloproteinase (MMP) and } \\
\text { proteasome activities in cells by peel } \\
\text { extracts for colon cancer }\end{array}$ & $\begin{array}{l}\text { The extracts inhibited proteasome (responsible } \\
\text { for the degradation } \\
\text { of cell regulatory proteins, found in excess in } \\
\text { tumor cells) activity in extract-treated cells, } \\
\text { inhibiting the progression of cancer }\end{array}$ & [299] \\
\hline $\begin{array}{l}\text { Peel of Citrus } \\
\text { aurantifolia and } \\
\text { Citrus reticulata }\end{array}$ & $\begin{array}{l}\text { Citrus peel like a natural model for } \\
\text { cancer prevention and treatment }\end{array}$ & $\begin{array}{l}\text { Hesperidin and naringenin increased the } \\
\text { cytotoxicity of doxorubicin in cancer cells } \\
\text { (MCF-7 and HeLa). Hesperidin can lower the } \\
\text { concentration of liver and serum lipids and } \\
\text { reduce osteoporosis }\end{array}$ & [300] \\
\hline $\begin{array}{l}\text { Pineapple peel } \\
\text { (Ananas comosus) }\end{array}$ & $\begin{array}{l}\text { Determination of extraction methods, } \\
\text { purification, and therapeutic } \\
\text { applications of bromelain }\end{array}$ & $\begin{array}{l}\text { Medicinal applications: inhibition of platelet } \\
\text { aggregation, antithrombotic, } \\
\text { anti-inflammatory, modulation of cytokines, } \\
\text { and immunity }\end{array}$ & [301] \\
\hline $\begin{array}{c}\text { Mango seed } \\
\text { (Mangifera indica) }\end{array}$ & $\begin{array}{l}\text { Cytotoxic effect of the by-product } \\
\text { extract on MDA-MB-231 and } \\
\text { MCF-7 cancer cells }\end{array}$ & $\begin{array}{l}\text { The extract induced cytotoxicity in } \\
\text { MDA-MB-231 and MCF-7 cells with IC50 } \\
\text { values of } 30 \text { and } 15 \mu \mathrm{g} / \mathrm{mL} \text {, respectively }\end{array}$ & [302] \\
\hline $\begin{array}{l}\text { Broccoli residues } \\
\text { (Brassica oleracea var. } \\
\text { Italica) }\end{array}$ & $\begin{array}{c}\text { Inhibitory effect of broccoli sprout } \\
\text { extracts on prostate cancer cell phones } \\
\text { with low (AT-2) and high (MAT-LyLu) } \\
\text { metastatic potential }\end{array}$ & $\begin{array}{c}\text { Efficiency in the inhibition of cell proliferation, } \\
\text { motility, and cell coupling was obtained } \\
\text { using the extracts }\end{array}$ & [303] \\
\hline $\begin{array}{l}\text { Grape pomace } \\
\text { (Vitis vinifera) }\end{array}$ & $\begin{array}{l}\text { By-product effects on metabolism and } \\
\text { redox status in HepG } 2 \text { human } \\
\text { hepatocarcinoma cells }\end{array}$ & $\begin{array}{c}\text { Long-term metabolic effects generated } \\
\text { cytotoxicity, and cells died from necrosis, and } \\
\text { it was not toxic to non-cancerous } \\
\text { human fibroblasts }\end{array}$ & [304] \\
\hline $\begin{array}{l}\text { Grapefruit peel } \\
\text { (Citrus paradisi) }\end{array}$ & $\begin{array}{l}\text { Grapefruit peel essential oil as an active } \\
\text { component against strains of Candida } \\
\text { albicans isolated from patients with } \\
\text { sub-protein stomatitis }\end{array}$ & $\begin{array}{l}\text { Citrus paradisi essential oil at } 25 \% \text { and } 12.5 \% \\
\text { presented a limited antifungal activity, and that } \\
\text { presents inhibition halos of greater diameter }\end{array}$ & [290] \\
\hline
\end{tabular}


Table 17. Cont.

\begin{tabular}{|c|c|c|c|}
\hline By-Product & Study & Result & Reference \\
\hline $\begin{array}{l}\text { Peel and leaves of } \\
\text { kafir lime } \\
\text { (Citrus hystrix) }\end{array}$ & $\begin{array}{l}\text { Inhibitory effect of essential oils of } \\
\text { by-products against respiratory } \\
\text { pathogens (Streptococcus pneumoniae, } \\
\text { Haemophilus influenzae, Staphylococcus } \\
\text { aureus, and Acinetobacter baumannii) and } \\
\text { evaluation of their active components }\end{array}$ & $\begin{array}{l}\text { Twenty-five components identified in the } \\
\text { extract, limonene as the main compound with } \\
\text { yields of } 91.5 \text { and } 88.6 \% \text { of antibacterial activity }\end{array}$ & [305] \\
\hline
\end{tabular}

\subsubsection{Antivirals}

According to biological terminology, the word virus originates from the Latin virus meaning toxin or poison [306]. Viruses are acellular infectious agent particles with nucleic acids (deoxyribonucleic acid, DNA, and ribonucleic acid, RNA) [307]. They are classified mainly by their phenotypic characteristics such as nucleic acid type, proteins, replicative cycle, and the viral infection produced [306]. A protein envelope generally encapsulates some called a capsid, others by a cell membrane or an envelope derived from the infected cell [308]. The evolution of viruses has increased their ability to multiply within the infected cell because they cannot do it by themselves due to the lack of necessary molecular material [309]. Viruses have been the leading cause of severe and chronic infections, causing the death or degeneration of host cells, capable of multiplying rapidly in the human body. Due to their rapid evolution, several mutations have produced new deadly diseases [308]. Therefore, scientific studies in the field of medicine have expanded their perspective to new alternatives to counteract viruses such as hepatitis, Ebola, MERS-CoV (Middle East Respiratory Syndrome), H7N9 (avian influenza virus), Crimean-Congo fever, among others [310].

The bioactive compounds present in many foods have been of great interest for their antiviral capacities, reducing infected cells' activity and inhibiting multiplication in the body. Flavonoid compounds such as tangeretin, nobiletin, and hesperidin have shown application as antivirals (Table 18) [311]. Tang et al. [312] obtained tangeretin from citrus fruit peels and demonstrated a high capacity to inhibit the Lassa virus's entry (the principalagent causing viral hemorrhagic fever, VHF) to the host cells and blocking the viral fusion.

Table 18. Different residues as a source of phenolic compounds and their application in the prevention of viral infections.

\begin{tabular}{cccc}
\hline By-Product & Compounds & Virus & Result \\
\hline Citrus reticulate peel & Tangeretin & $\begin{array}{c}\text { Human respiratory } \\
\text { syncytial virus (RSV) }\end{array}$ & $\begin{array}{c}\text { Inhibition of RSV replication } \\
\text { and decreased inflammation } \\
\text { in lungs }\end{array}$ \\
\hline $\begin{array}{c}\text { Peels of Citrus } \\
\text { madurensis Lour }\end{array}$ & $\begin{array}{c}\text { Hesperidin, diosmin, } \\
\text { neohesperidin, } \\
\text { nobiletin, tangeretin }\end{array}$ & Hepatitis B virus & $\begin{array}{c}\text { Significantly inhibited the } \\
\text { surface antigen of the } \\
\text { hepatitis B virus }\end{array}$ \\
\hline Citrus fruit peel & Nobiletin & Hepatitis B virus & $\begin{array}{c}\text { Inhibited surface antigen and } \\
\text { hepatitis B virus }\end{array}$ \\
\hline Citrus reticulate peel & Nobiletin & Chikungunya virus & $\begin{array}{c}\text { Reduced the load of the virus } \\
\text { and exerts a positive effect } \\
\text { on the immune system }\end{array}$ \\
\hline
\end{tabular}

Currently, the world is affected by the pandemic crisis caused by the severe acute respiratory syndrome virus (SARS-CoV-2), a descendant of the SARS-CoV coronavirus family, which causes the coronavirus disease (COVID-19) [317]. This virus consists of a genome of positive-sense single-stranded RNA, enveloped by a lipid membrane with structural proteins. The structural proteins are the protein S (glycoprotein homotrimer) responsible for the appearance and recognition of receptors on the target cell, the protein $\mathrm{M}$ 
(membrane glycoprotein) with greater abundance on the surface of the virus, which defines the shape of the lipid membrane, and protein E (a small membrane protein) involved in several processes of the viral cycle [318]. Due to the accelerated increase in cases of contagion and the chronic affectations that this virus presents, alternative drugs, and compounds have been studied for the prevention and inhibition of the virus, such as Arbidol, with a direct antiviral effect on the early viral replication of the virus, Remdesivir, which has a significant effect against a wide range of RNA virus infections, and Lopinavir, a protease inhibitor [18]. Because it is a recently discovered virus, studies in the formulation of a vaccine require an intense investigation of highly efficient compounds to eliminate the virus [318]. However, medical advances in antibody development have accelerated vaccine development. At least 240 vaccines are currently in process (phase I), 44 in clinical trials (phase II) at the time of the writing of this review, so the number of vaccines in development increases daily [319]. Six vaccines are currently in phase III [Johnson \& Johnson (United States), AstraZeneca (University of Oxford, United Kingdom), Sinovac (China), Sinopharm (China), Moderna (United States), and Pfizer (United States)] [320]. In this phase, the vaccine's safety and efficacy against the SARS-CoV-2 virus are more fully evaluated until reaching the final phase (IV), where it is approved [320]. According to the World Health Organization (WHO) report, vaccines' effect in providing an immune barrier still needs more research [321]. The food loss and wastes present bioactive compounds that generate medicinal effects such as the inhibition of viral activity and the reduction of inflammation in the affected organism, such as hesperidin, a phenolic compound with antioxidant, anti-inflammatory properties, which production could be less expensive. For this reason, the potential of hesperidin, mostly found in the by-products of citrus fruit peels, has been studied (Table 19).

Table 19. Research on the efficiency of hesperidin from citrus fruit peels to counteract the SARS-CoV-2 virus.

\begin{tabular}{|c|c|c|c|}
\hline By-Product & Study & Result & Reference \\
\hline $\begin{array}{l}\text { Peels of lime (C. Aurantifolia), } \\
\text { grapefruit (C. maxima), lemon } \\
\text { (C. jambhiri), lime (C. limetta), } \\
\text { grapefruit (C. medica L.), } \\
\text { mandarin (C. reticulata), and } \\
\text { mandarin (C. reticulate white) }\end{array}$ & $\begin{array}{l}\text { Identification of the added value } \\
\text { of the by-product through } \\
\text { different extraction methods and } \\
\text { its potential utility } \\
\text { against COVID-19 }\end{array}$ & $\begin{array}{l}\text { The amount of iron and phenols was } \\
\text { higher in grapefruit and grapefruit peel } \\
\text { compared to other species, obtaining } \\
\text { bioactive compounds and medicinal } \\
\text { phytochemicals such as flavonoids for } \\
\text { the treatment of COVID-19 }\end{array}$ & [322] \\
\hline Assorted citrus peels & $\begin{array}{l}\text { Review of varieties of citrus } \\
\text { by-products as a source of } \\
\text { hesperidin, an active compound } \\
\text { against COVID-19 and its } \\
\text { extraction process }\end{array}$ & $\begin{array}{l}\text { Hesperidin has a strong binding } \\
\text { affinity for all significant viruses such } \\
\text { as SARS-CoV and their mutations with } \\
\text { the potential to prevent it from } \\
\text { spreading to cells; likewise, hesperetin } \\
\text { (hesperidin aglycone) and naringin } \\
\text { stop the pro-inflammatory reaction of } \\
\text { the immune system }\end{array}$ & [288] \\
\hline Orange peel (Citrus $\times$ sinensis) & $\begin{array}{c}\text { Study of hesperidin as a source to } \\
\text { counteract the SARS-CoV-2 virus } \\
\text { from citrus fruits }\end{array}$ & $\begin{array}{l}\text { Hesperidin showed a good safety } \\
\text { profile, with a median lethal dose } \\
\left(\mathrm{LD}_{50}\right) \text { of } 4837.5 \mathrm{mg} / \mathrm{kg} \text {. A dose } \\
\text { administration of } 500 \mathrm{mg} / \mathrm{kg} \text { of } \\
\text { flavanone did not induce any } \\
\text { abnormality in body weight, clinical } \\
\text { signs, symptoms, and blood parameters }\end{array}$ & [18] \\
\hline Assorted citrus peels & $\begin{array}{l}\text { The feasibility of hesperidin for } \\
\text { the treatment of COVID-19 }\end{array}$ & $\begin{array}{l}\text { Hesperidin targets the root of the } \\
\text { infection by binding the protein spike }\end{array}$ & [323] \\
\hline
\end{tabular}

\section{Conclusions and Perspectives}

The agri-food industry generates a large amount of waste that can be applied for food, medicinal, and skincare products by extracting bioactive compounds. Flours obtained from 
seeds and skins of fruits and cereals presented better sensory and nutritional characteristics in the partial substitution of 10,20 and 30\% of wheat flour and corn in the preparation of bread and cookies, having a consumer acceptance of 90 to $100 \%$. Fruit peels are a good source of colorants that, in addition to contributing to the color in bakery products, provide antioxidant and anti-inflammatory capabilities, proposing their application in the development of new functional foods. Likewise, they are an excellent substrate to produce bromelain enzymes of great interest at an industrial level. Studies carried out to date indicate that the phenolic compounds present in citrus fruit residues have a broad medicinal activity, increasing the protection capacity against chronic diseases such as cancer thanks to their antioxidant, anti-inflammatory, antibacterial properties. On the other hand, tangeretin, nobiletin, and hesperidin turn out antigens' inhibitors fighting respiratory and hepatic viruses, exhibiting a potential application in pharmaceutical applications. To develop the industry in the extraction of natural colorants from FLW, extraction methods must be carried out more thoroughly on a pilot scale, expanding the panorama and the technoeconomic feasibility due to consumers' great demand to acquire clean product labels.

The reviewed studies demonstrated the potential use of food loss and waste, and its future application on an industrial scale, with lower energy consumption processes. The studies also highlight the potential of the by-products for the human and animal feed population, avoiding excessive consumption of raw materials. There is little literature on the study and analysis of colorants extracted from food losses and waste applied to confectionery products. It is essential to investigate the possible application of naturally derived naturals colorants in beverages, sweets, and candies in the confectionery industry. It is essential to investigate the potential application of derived natural dyes in beverages, sweets, and candies in the confectionery industry. Similarly, the appropriate doses should be thoroughly investigated to effectively counteract viral diseases with phenolic compounds derived from fruit peels, generating new alternatives for low-cost medicine production.

Author Contributions: Conceptualization, C.D.G.-T., L.L.D.R.O., and E.F.-L.; formal analysis, C.D.G.T. and L.L.D.R.O.; investigation, C.D.G.-T. and L.L.D.R.O.; methodology, C.D.G.-T. and L.L.D.R.O.; project administration, C.D.G.-T. and E.F.-L.; supervision, C.D.G.-T.; writing-original draft, C.D.G.-T. and L.L.D.R.O.; writing-review and editing, L.L.D.R.O., E.F.-L., and C.D.G.-T. All authors have read and agreed to the published version of the manuscript.

Funding: This research received no external funding. The APT was funded by Universidad Santiago de Cali.

Institutional Review Board Statement: Not applicable.

Informed Consent Statement: Not applicable.

Acknowledgments: E.F.-L. acknowledges Universidad Santiago de Cali for APC payment.

Conflicts of Interest: The authors declare no conflict of interest.

Sample Availability: Samples of the compounds are not available from the authors.

\section{References}

1. Tomiyama, J.-M.; Takagi, D.; Kantar, M.B. The effect of acute and chronic food shortage on human population equilibrium in a subsistence setting. Agric. Food Secur. 2020, 9, 1-2. [CrossRef]

2. World Food Programme Zero Hungry. Available online: https://www.wfp.org/zero-hunger (accessed on 17 November 2020).

3. Garza-Reyes, J.A.; Kumar, V.; Batista, L.; Cherrafi, A.; Rocha-Lona, L. From linear to circular manufacturing business models. J. Manuf. Technol. Manag. 2019, 30, 554-560. [CrossRef]

4. Subramanian, K.R. The Crisis of Consumption of Natural Resources. Int. J. Recent Innov. Acad. Res. 2018, 2, 8-19.

5. Castrica, M.; Rebucci, R.; Giromini, C.; Tretola, M.; Cattaneo, D.; Baldi, A. Total phenolic content and antioxidant capacity of agri-food waste and by-products. Ital. J. Anim. Sci. 2019, 18, 336-341. [CrossRef]

6. Shafiee-Jood, M.; Cai, X. Reducing Food Loss and Waste to Enhance Food Security and Environmental Sustainability. Environ. Sci. Technol. 2016, 50, 8432-8443. [CrossRef] [PubMed]

7. Van der Werf, P.; Gilliland, J.A. A systematic review of food losses and food waste generation in developed countries. Proc. Inst. Civ. Eng. Waste Resour. Manag. 2017, 170, 66-77. [CrossRef] 
8. Ziolkowska, J.R. Economic and Environmental Costs of Agricultural Food Losses and Waste in the US. Int. J. Food Eng. 2017, 3. [CrossRef]

9. Bilali, H.E.; El Bilali, H. Research on food losses and waste in North Africa. N. Afr. J. Food Nutr. Res. 2018, 2, 51-57.

10. Hoehn, D.; Laso, J.; Cristóbal, J.; Ruiz-Salmón, I.; Butnar, I.; Borrion, A.; Bala, A.; Fullana-i-Palmer, P.; Vázquez-Rowe, I.; Aldaco, R.; et al. Regionalized Strategies for Food Loss and Waste Management in Spain under a Life Cycle Thinking Approach. Foods 2020, 9, 1765. [CrossRef]

11. Brenes-Peralta, L.; Jiménez-Morales, M.F.; Freire Junior, M.; Belik, W.; Basso, N.; Polenta, G.; Giraldo, C.; Granados, S. Challenges and Initiatives in Reducing Food Losses and Waste: Latin America and the Caribbean; Burleigh Dodds Science Publishing: Cambridge, UK, 2020.

12. Beretta, C.; Stucki, M.; Hellweg, S. Environmental Impacts and Hotspots of Food Losses: Value Chain Analysis of Swiss Food Consumption. Environ. Sci. Technol. 2017, 51, 11165-11173. [CrossRef]

13. Porter, S.D.; Reay, D.S.; Higgins, P.; Bomberg, E. A half-century of production-phase greenhouse gas emissions from food loss \& waste in the global food supply chain. Sci. Total Environ. 2016, 571, 721-729. [CrossRef] [PubMed]

14. Kinach, L.; Parizeau, K.; Fraser, E.D.G. Do food donation tax credits for farmers address food loss/waste and food insecurity? A case study from Ontario. Agric. Human. Values 2020, 37, 383-396. [CrossRef] [PubMed]

15. Esposito, B.; Sessa, M.R.; Sica, D.; Malandrino, O. Towards circular economy in the agri-food sector. A systematic literature review. Sustainability 2020, 12, 7401. [CrossRef]

16. Panzella, L.; Moccia, F.; Nasti, R.; Marzorati, S.; Verotta, L.; Napolitano, A. Bioactive Phenolic Compounds From Agri-Food Wastes: An Update on Green and Sustainable Extraction Methodologies. Front. Nutr. 2020, 7, 60. [CrossRef] [PubMed]

17. Galanakis, C.M. The Food Systems in the Era of the Coronavirus (COVID-19) Pandemic Crisis. Foods 2020, 9, 523. [CrossRef] [PubMed]

18. Bellavite, P.; Donzelli, A. Hesperidin and SARS-CoV-2: New Light on the Healthy Function of Citrus Fruits. Antioxidants 2020, 9 , 742. [CrossRef]

19. Hobbs, J.E. Food supply chains during the COVID-19 pandemic. Can. J. Agric. Econ. Can. D'agroecon. 2020, 68, 171-176. [CrossRef]

20. Haseeb, M.; Zandi, G.; Hartani, N.H.; Pahi, M.H.; Nadeem., S.U. Environmental Analysis of the Effect of Population Growth Rate on Supply Chain Performance and Economic Growth of Indonesia. Ekoloji Derg. 2019, 28, 417-426.

21. Maqbool, A.; Khan, S.; Haleem, A.; Khan, M.I. Investigation of Drivers Towards Adoption of Circular Economy: A DEMATEL Approach. In Recent Advances in Mechanical Engineering; Springer: Singapore, 2020; pp. 147-160.

22. Pagotto, M.; Halog, A. Towards a Circular Economy in Australian Agri-food Industry: An Application of Input-Output Oriented Approaches for Analyzing Resource Efficiency and Competitiveness Potential. J. Ind. Ecol. 2016, 20, 1176-1186. [CrossRef]

23. Del Borghi, A.; Moreschi, L.; Gallo, M. Circular economy approach to reduce water-energy-food nexus. Curr. Opin. Environ. Sci. Heal. 2020, 13, 23-28. [CrossRef]

24. Jurgilevich, A.; Birge, T.; Kentala-Lehtonen, J.; Korhonen-Kurki, K.; Pietikäinen, J.; Saikku, L.; Schösler, H. Transition towards Circular Economy in the Food System. Sustainability 2016, 8, 69. [CrossRef]

25. Sharma, Y.K.; Mangla, S.K.; Patil, P.P.; Liu, S. When challenges impede the process: For circular economy-driven sustainability practices in food supply chain. Manag. Decis. 2019, 57, 995-1017. [CrossRef]

26. Genovese, A.; Acquaye, A.A.; Figueroa, A.; Koh, S.C.L. Sustainable supply chain management and the transition towards a circular economy: Evidence and some applications. Omega 2017, 66, 344-357. [CrossRef]

27. Lewandowski, M. Designing the Business Models for Circular Economy-Towards the Conceptual Framework. Sustainability 2016, 8, 43. [CrossRef]

28. Cingiz, K.; Wesseler, J. Opportunities and the Policy Challenges to the Circular Agri-Food System. In EU Bioeconomy Economics and Policies; Palgrave Macmillan: Chambridge, UK, 2019; pp. 293-318.

29. Barros, M.V.; Salvador, R.; de Francisco, A.C.; Piekarski, C.M. Mapping of research lines on circular economy practices in agriculture: From waste to energy. Renew. Sustain. Energy Rev. 2020, 131, 109958. [CrossRef]

30. Ingrao, C.; Faccilongo, N.; Di Gioia, L.; Messineo, A. Food waste recovery into energy in a circular economy perspective: A comprehensive review of aspects related to plant operation and environmental assessment. J. Clean. Prod. 2018, 184, 869-892. [CrossRef]

31. Geueke, B.; Groh, K.; Muncke, J. Food packaging in the circular economy: Overview of chemical safety aspects for commonly used materials. J. Clean. Prod. 2018, 193, 491-505. [CrossRef]

32. Guillard, V.; Gaucel, S.; Fornaciari, C.; Angellier-Coussy, H.; Buche, P.; Gontard, N. The Next Generation of Sustainable Food Packaging to Preserve Our Environment in a Circular Economy Context. Front. Nutr. 2018, 5, 121. [CrossRef]

33. Murray, A.; Skene, K.; Haynes, K. The Circular Economy: An Interdisciplinary Exploration of the Concept and Application in a Global Context. J. Bus. Ethics 2017, 140, 369-380. [CrossRef]

34. Geissdoerfer, M.; Savaget, P.; Bocken, N.M.P.; Hultink, E.J. The Circular Economy-A new sustainability paradigm? J. Clean. Prod. 2017, 143, 757-768. [CrossRef]

35. Macarthur, E. Towards the circular economy. J. Ind. Ecol. 2013, 2, $23-44$.

36. Stahel, W.R. The circular economy. Nature 2016, 7595, 435-438. [CrossRef] [PubMed]

37. Brown, M.T.; Buranakarn, V. Emergy indices and ratios for sustainable material cycles and recycle options. Resour. Conserv. Recycl. 2003, 38, 1-22. [CrossRef] 
38. Velenturf, A.P.M.; Archer, S.A.; Gomes, H.I.; Christgen, B.; Lag-Brotons, A.J.; Purnell, P. Circular economy and the matter of integrated resources. Sci. Total Environ. 2019, 689, 963-969. [CrossRef]

39. Xue, L.; Liu, G. Introduction to global food losses and food waste. In Saving Food: Production, Supply Chain, Food Waste and Food Consumption; Elsevier: Amsterdam, The Netherlands, 2019; pp. 1-31, ISBN 9780128153574.

40. Fan, Y.; Fang, C. Circular economy development in China-current situation, evaluation and policy implications. Environ. Impact Assess. Rev. 2020, 84, 106441. [CrossRef]

41. Liu, L.; Liang, Y.; Song, Q.; Li, J. A review of waste prevention through 3R under the concept of circular economy in China. J. Mater. Cycles Waste Manag. 2017, 19, 1314-1323. [CrossRef]

42. Sze, C.; Lin, K.; Mubofu, E.B.; Pfaltzgraff, L.A.; Herrero-Davila, L.; Abderrahim, S.; Clark, J.H.; Koutinas, A.A.; Kopsahelis, N.; Stamatelatou, K.; et al. Food waste as a valuable resource for the production of chemicals, materials and fuels. Current situation and global perspective. Energy Environ. Sci. 2013, 6, 426-464. [CrossRef]

43. Salemdeeb, R.; zu Ermgassen, E.K.H.J.; Kim, M.H.; Balmford, A.; Al-Tabbaa, A. Environmental and health impacts of using food waste as animal feed: a comparative analysis of food waste management options. J. Clean. Prod. 2017, 140, 871-880. [CrossRef]

44. Candida, V.; Fernando, C.; Margarida, G.; Ana Luísa, F. Wastes: Solutions, Treatments and Opportunities III: Selected Papers from e 5th International Conference Wastes 2019, September 4-6, 2019, Lisbon, Portugal; Candida, V., Fernando, C., Margarida, G., Ana Luísa, F., Eds.; CRC Press: Boca Raton, FL, USA, 2019; Volume 3.

45. Bergesen, H.O.; Parmann, G.; Thommessen, O.B. Convention on the Control of Transboundary Movements of Hazardous Wastes and their Disposal (Basel Convention). Yearb. Int. Coop. Environ. Dev. 2019, 87-89. [CrossRef]

46. Donner, M.; Verniquet, A.; Broeze, J.; Kayser, K.; De Vries, H. Critical success and risk factors for circular business models valorising agricultural waste and by-products. Resour. Conserv. Recycl. 2021, 165, 105236. [CrossRef]

47. Commission, E. Communication from the Commission to the European Parliament, the Council, the European Economic and Social Committee and the Committee of the Regions; European Commission: Brussels, Belgium, 2011.

48. Garske, B.; Heyl, K.; Ekardt, F.; Weber, L.M.; Gradzka, W. Challenges of food waste governance: An assessment of European legislation on food waste and recommendations for improvement by economic instruments. Land 2020, 9, 231. [CrossRef]

49. Alexa Teigiserova, D.; Hamelin, L.; Thomsen, M.; Hamelin, L. Towards transparent valorization of food surplus, waste and loss: Clarifying definitions, food waste hierarchy, and role in the circular economy. Sci. Total Environ. 2019, 706. [CrossRef] [PubMed]

50. Parry, A.; Bleazard, P.; Okawa, K. Preventing Food Waste: Case Studies of Japan and the United Kingdom. OECD 2015, 76, 50.

51. Chalak, A.; Abou-Daher, C.; Chaaban, J.; Abiad, M.G. The global economic and regulatory determinants of household food waste generation: A cross-country analysis. Waste Manag. 2016, 48, 418-422. [CrossRef]

52. Mo, W.Y.; Man, Y.B.; Wong, M.H. Use of food waste, fish waste and food processing waste for China's aquaculture industry: Needs and challenge. Sci. Total Environ. 2018, 613-614, 635-643. [CrossRef]

53. Mena, C.; Adenso-Diaz, B.; Yurt, O. The causes of food waste in the supplier-retailer interface: Evidences from the UK and Spain. Resour. Conserv. Recycl. 2011, 55, 648-658. [CrossRef]

54. Melikoglu, M.; Sze, C.; Lin, K.; Webb, C. Analysing global food waste problem: pinpointing the facts and estimating the energy content. Cent. Eur. J. Eng. 2013, 3, 157-164. [CrossRef]

55. Shehzad, A.; Bashir, M.J.K.; Sethupathi, S.; Lim, J.W. An overview of heavily polluted landfill leachate treatment using food waste as an alternative and renewable source of activated carbon. Process Saf. Environ. Prot. 2015, 98, 309-318. [CrossRef]

56. Ezeah, C.; Byrne, T. A Critical Review of Municipal Solid Waste Legislation and Compliance in Greece-In the Context of the EU Landfill Directive. J. Environ. Sci. Toxicol. Food Technol. 2014, 8, 81-89. [CrossRef]

57. Angelonidi, E.; Smith, S.R. A comparison of wet and dry anaerobic digestion processes for the treatment of municipal solid waste and food waste. Water Environ. J. 2015, 29, 549-557. [CrossRef]

58. Duarte, S.; Osuna, S.; Alexandra, J.; Miranda, R.; Pablo, J. Sustainable Use of Organic Solid Waste: A Conceptual Review through the Waste Pickers Organizations. Int. J. Eng. Res. Technol. 2020, 13, 2055-2066. [CrossRef]

59. Rudnik, E. Compostable Polymer Materials; Newnes: Oxford, UK, 2019.

60. Pietro, G. Economía Circular e Innovación Tecnológica en Residuos Sólidos: Oportunidades en América Latina; Suárez, J., Ed.; Corporación Andina de Fomento: Buenos Aires, Argentina, 2018.

61. De Clercq, D.; Wen, Z.; Gottfried, O.; Schmidt, F.; Fei, F. A review of global strategies promoting the conversion of food waste to bioenergy via anaerobic digestion. Renew. Sustain. Energy Rev. 2017, 79, 204-221. [CrossRef]

62. Ma, H.; Guo, Y.; Qin, Y.; Li, Y.Y. Nutrient recovery technologies integrated with energy recovery by waste biomass anaerobic digestion. Bioresour. Technol. 2018, 269, 520-531. [CrossRef] [PubMed]

63. Esparza, I.; Jiménez-Moreno, N.; Bimbela, F.; Ancín-Azpilicueta, C.; Gandía, L.M. Fruit and vegetable waste management: Conventional and emerging approaches. J. Environ. Manag. 2020, 265, 110510. [CrossRef]

64. Pham, T.P.T.; Kaushik, R.; Parshetti, G.K.; Mahmood, R.; Balasubramanian, R. Food waste-to-energy conversion technologies: Current status and future directions. Waste Manag. 2015, 38, 399-408. [CrossRef]

65. Galanakis, C.M. Food Waste Recovery: Processing Technologies and Industrial Techniques; Academic Press: Cambridge, MA, USA, 2015; ISBN 9780128004197.

66. Kalogirou, E. Waste-to-Energy Technologies and Global Applications; CRC Press: Boca Raton, FL, USA, 2017.

67. Tozlu, A.; Özahi, E.; Energy, A.A.-R.U. Waste to energy technologies for municipal solid waste management in Gaziantep. Renew. Sustain. Energy Rev. 2016, 54, 809-815. [CrossRef] 
68. Montejo, C.; Tonini, D.; Márquez, M.d.C.; Fruergaard Astrup, T. Mechanical-biological treatment: Performance and potentials. An LCA of 8 MBT plants including waste characterization. J. Environ. Manag. 2013, 128, 661-673. [CrossRef]

69. Fei, F.; Wen, Z.; Huang, S.; De Clercq, D. Mechanical biological treatment of municipal solid waste: Energy efficiency, environmental impact and economic feasibility analysis. J. Clean. Prod. 2018, 178, 731-739. [CrossRef]

70. Ghiffari, R.A. Development of Eucalyptus Oil Agro-industries in Kabupaten Buru. Procedia Soc. Behav. Sci. 2016, 227, 815-823. [CrossRef]

71. Mullen, A.M.; Álvarez, C.; Pojić, M.; Hadnadev, T.D.; Papageorgiou, M. Classification and target compounds. In Food Waste Recovery: Processing Technologies and Industrial Techniques; Elsevier: Amsterdam, The Netherlands, 2015; pp. 25-57, ISBN 9780128004197.

72. Paiva, T.; Ribeiro, M.; Coutinho, P. R\&D Collaboration, Competitiveness Development, and Open Innovation in R\&D. J. Open Innov. Technol. Mark. Complex. 2020, 6, 116. [CrossRef]

73. Karwacka, M.; Ciurzyńska, A.; Lenart, A.; Janowicz, M. Sustainable Development in the Agri-Food Sector in Terms of the Carbon Footprint: A Review. Sustainability 2020, 12, 6463. [CrossRef]

74. Bachev, H. Risk Management in the Agri-Food Sector. Contemp. Econ. 2013, 7, 45-62. [CrossRef]

75. United States Departament of Agriculture. World Agricultural Production; United States Departament of Agriculture: Washington, DC, USA, 2020.

76. Taylor, D.H.; Soosay, C.; Fearne, A.; Dent, B.; Barber, E. Value chain analysis: an approach to supply chain improvement in agri-food chains. Int. J. Phys. Distrib. Logist. Manag. 2005, 35, 141-162. [CrossRef]

77. De Moraes, C.C.; de Oliveira Costa, F.H.; Roberta Pereira, C.; da Silva, A.L.; Delai, I. Retail food waste: mapping causes and reduction practices. J. Clean. Prod. 2020, 256, 120124. [CrossRef]

78. Sherwood, J. The significance of biomass in a circular economy. Bioresour. Technol. 2020, 300, 122755. [CrossRef] [PubMed]

79. Al-Rumaihi, A.; McKay, G.; Mackey, H.R.; Al-Ansari, T. Environmental Impact Assessment of Food Waste Management Using Two Composting Techniques. Sustainability 2020, 12, 1595. [CrossRef]

80. Trigo, J.P.; Alexandre, E.M.C.; Saraiva, J.A.; Pintado, M.E. High value-added compounds from fruit and vegetable by-productsCharacterization, bioactivities, and application in the development of novel food products. Crit. Rev. Food Sci. Nutr. 2020, 60, 1388-1416. [CrossRef] [PubMed]

81. Food and Agriculture Organization of the United Nations FAOSTAT. Available online: http://www.fao.org/faostat/en/\#data/ QC (accessed on 18 November 2020).

82. Pu, M.; Zhong, Y. Rising concerns over agricultural production as COVID-19 spreads: Lessons from China. Glob. Food Sec. 2020, 26, 100409. [CrossRef]

83. Amit, S.K.; Uddin, M.M.; Rahman, R.; Islam, S.M.R.; Khan, M.S. A review on mechanisms and commercial aspects of food preservation and processing. Agric. Food Secur. 2017, 6, 1-22. [CrossRef]

84. Balasubramanian, S.A.K.; Kalne, A.A.; Khan, K.A.U. Effects of Processing on Vitamins in Fruits and Vegetables. In Processing of the Fruits and Vegetables: From Farm to Fork; CRC Press: Boca Raton, FL, USA, 2019; p. 324.

85. Anaya-Esparza, L.M.; Velázquez-Estrada, R.M.; Roig, A.X.; García-Galindo, H.S.; Sayago-Ayerdi, S.G.; Montalvo-González, E. Thermosonication: An alternative processing for fruit and vegetable juices. Trends Food Sci. Technol. 2017, 61, 26-37. [CrossRef]

86. Peters, K. Technology of Fruits and Vegetable Processing; Scientific e-Resources: 2019; ED-Tech Press: Waltham Abbey, UK, 2019; p. 334, ISBN 1839472626.

87. Crino, M.; Barakat, T.; Trevena, H.; Neal, B. Systematic Review and Comparison of Classification Frameworks Describing the Degree of Food Processing. Nutr. Food Technol. 2017, 3. [CrossRef]

88. Sagar, N.A.; Pareek, S.; Sharma, S.; Yahia, E.M.; Lobo, M.G. Fruit and Vegetable Waste: Bioactive Compounds, Their Extraction, and Possible Utilization. Compr. Rev. Food Sci. Food Saf. 2018, 17, 512-531. [CrossRef] [PubMed]

89. Lozano, J.E. Fruit Manufacturing; Springer: Berlin/Heidelberg, Germany, 2006.

90. Panda, H. Recovery, Fruit Waste Utilization, Waste Utilization of Fruits and Vegetables, Fruit and Vegetable Waste Management, Waste Utilization in Food Industry Method for Quantitative Recovery of . . . ; Asia Pacific Business Press: Delhi, India, 2011.

91. Jiménez-Moreno, N.; Esparza, I.; Bimbela, F.; Gandía, L.M.; Ancín-Azpilicueta, C. Valorization of selected fruit and vegetable wastes as bioactive compounds: Opportunities and challenges. Crit. Rev. Environ. Sci. Technol. 2020, 50, 2061-2108. [CrossRef]

92. Fidelis, M.; de Moura, C.; Kabbas Junior, T.; Pap, N.; Mattila, P.; Mäkinen, S.; Putnik, P.; Bursać Kovačević, D.; Tian, Y.; Yang, B.; et al. Fruit Seeds as Sources of Bioactive Compounds: Sustainable Production of High Value-Added Ingredients from By-Products within Circular Economy. Molecules 2019, 24, 3854. [CrossRef] [PubMed]

93. Sukruansuwan, V.; Napathorn, S.C. Use of agro-industrial residue from the canned pineapple industry for polyhydroxybutyrate production by Cupriavidus necator strain A-04. Biotechnol. Biofuels 2018, 11, 1-15. [CrossRef] [PubMed]

94. Folinas, D.; Aidonis, D.; Karayannakidis, P. Greening the canned peach production. J. Agric. Inform. 2015, 6, 24-39. [CrossRef]

95. Barbulova, A.; Colucci, G.; Apone, F. New Trends in Cosmetics: By-Products of Plant Origin and Their Potential Use as Cosmetic Active Ingredients. Cosmetics 2015, 2, 82-92. [CrossRef]

96. Raj, D.; Senapati, A. Waste Management in Horticulture Processing Industry. In Commercial Horticulture; Patel, N.L., Chawla, S.L., Ahlawat, T.R., Eds.; New India Publishing Agency: Delhi, India, 2016; pp. 391-401.

97. Van Dyk, J.S.; Gama, R.; Morrison, D.; Swart, S.; Pletschke, B.I. Food processing waste: Problems, current management and prospects for utilisation of the lignocellulose component through enzyme synergistic degradation. Renew. Sustain. Energy Rev. 2013, 26, 521-531. [CrossRef] 
98. Gülcü, M.; Uslu, N.; Özcan, M.M.; Gökmen, F.; Özcan, M.M.; Banjanin, T.; Gezgin, S.; Dursun, N.; Geçgel, Ü.; Ceylan, D.A.; et al. The investigation of bioactive compounds of wine, grape juice and boiled grape juice wastes. J. Food Process. Preserv. 2019, 43, e13850. [CrossRef]

99. Ros, M.; Pascual, J.; Ayuso, M.; Morales, A.; Miralles, J. Salidas valorizables de los residuos y subproductos orgánicos de la industria de los transformados de frutas y hortalizas: proyecto Life+ Agrowaste. Agrowaste.Eu 2012, 130, 2-9.

100. Rico, X.; Gullón, B.; Alonso, J.L.; Yáñez, R. Recovery of high value-added compounds from pineapple, melon, watermelon and pumpkin processing by-products: An overview. Food Res. Int. 2020, 132. [CrossRef]

101. kumar, V.; Singh, J.; Chandra, S.; Kumar, R.; Singh, K.; Chaudhary, V.; Kumar, P.; Scholar, R.; Professor, A. Post Harvest Technology of Papaya Fruits \& its Value Added Products-A Review. Int. J. Pure App. Biosci 2019, 7, 169-181. [CrossRef]

102. Joglekar, S.N.; Pathak, P.D.; Mandavgane, S.A.; Kulkarni, B.D. Process of fruit peel waste biorefinery: a case study of citrus waste biorefinery, its environmental impacts and recommendations. Environ. Sci. Pollut. Res. 2019, 26, 34713-34722. [CrossRef] [PubMed]

103. Senit, J.J.; Velasco, D.; Gomez Manrique, A.; Sanchez-Barba, M.; Toledo, J.M.; Santos, V.E.; Garcia-Ochoa, F.; Yustos, P.; Ladero, M. Orange peel waste upstream integrated processing to terpenes, phenolics, pectin and monosaccharides: Optimization approaches. Ind. Crop. Prod. 2019, 134, 370-381. [CrossRef]

104. Dibanda Romelle, F.; Ashwini, R.P.; Manohar, R.S. Chemical composition of some selected fruit peels. Eur. J. Food Sci. Technol. 2016, 4, 12-21.

105. Salem, R.H. Quality Characteristics of Beef Sausages with Tomato Peel as a Colour and Functional Additive During Frozen Storage. World Appl. Sci. J. 2013, 22, 1085-1093. [CrossRef]

106. Rincón, A.; Vásquez, A.; Latinoamericanos, F.P.-A.; 2005, U. Chemical composition and bioactive compounds of flour of orange (Citrus sinensis), tangerine (Citrus reticulata) and grapefruit (Citrus paradisi) peels cultivated in. Arch. Latinoam. Nutr. 2005, 55, 305-310.

107. Silva, I.M.; Gonzaga, L.V.; Amante, E.R.; Teófilo, R.F.; Ferreira, M.M.; Amboni, R.D. Optimization of extraction of high-ester pectin from passion fruit peel (Passiflora edulis flavicarpa) with citric acid by using response surface methodology. Bioresour. Technol. 2008. [CrossRef]

108. Alsayed, H.; Ahmed, A.R.; Al-Sayed, H.M.A. Utilization of watermelon rinds and sharlyn melon peels as a natural source of dietary fiber and antioxidants in cake. J. Food Sci. Technol. 2013, 6, 11-18. [CrossRef]

109. Raihana, A.R.N.; Marikkar, J.M.N.; Amin, I.; Shuhaimi, M. A Review on Food Values of Selected Tropical Fruits' Seeds. Int. J. Food Prop. 2015, 18, 2380-2392. [CrossRef]

110. Da Silva, A.C.; Jorge, N. Bioactive compounds of the lipid fractions of agro-industrial waste. Food Res. Int. 2014, 66, 493-500. [CrossRef]

111. Da Silva, A.C.; Jorge, N. Bioactive compounds of oils extracted from fruits seeds obtained from agroindustrial waste. Eur. J. Lipid Sci. Technol. 2017, 119, 1600024. [CrossRef]

112. Persia, M.E.; Parsons, C.M.; Schang, M.; Azcona, J. Nutritional evaluation of dried tomato seeds. Poult. Sci. 2003, 82, 141-146. [CrossRef] [PubMed]

113. Kim, H.S. Studies on the amino acid and fatty acid compositions in the seed and pulpy substance of feral peach (Prunus persica Batsch var. davidiana Max.). J. Life Sci. 2007, 17, 125-131. [CrossRef]

114. Yu, X.; Van De Voort, F.R.; Li, Z.; Yue, T. Proximate Composition of the Apple Seed and Characterization of Its Oil Proximate Composition of the Apple Seed and Characterization of Its Oil. Int. J. Food Eng. 2007, 3, 1-8. [CrossRef]

115. Felhi, S.; Baccouch, N.; Salah, H.B.; Smaoui, S.; Allouche, N.; Gharsallah, N.; Kadri, A. Nutritional constituents, phytochemical profiles, in vitro antioxidant and antimicrobial properties, and gas chromatography-mass spectrometry analysis of various solvent extracts from grape seeds (Vitis vinifera L.). Food Sci. Biotechnol. 2016, 25, 1537-1544. [CrossRef]

116. Onimawo, I.A.; Oteno, F.; Orokpo, G.; Akubor, P.I. Physicochemical and nutrient evaluation of African bush mango (Irvingia gabonensis) seeds and pulp. Plant Foods Hum. Nutr. 2003, 58, 1-6. [CrossRef]

117. Mallek-Ayadi, S.; Bahloul, N.; Kechaou, N. Chemical composition and bioactive compounds of Cucumis melo L. seeds: Potential source for new trends of plant oils. Process Saf. Environ. Prot. 2018, 113, 68-77. [CrossRef]

118. Zou, Y.; Ma, K.; Tian, M. Chemical composition and nutritive value of hot pepper seed (Capsicum annuum) grown in Northeast Region of China. Food Sci. Technol. 2015, 35, 659-663. [CrossRef]

119. El-safy, S.; Salem, R.; Abd El-Ghany, M. Chemical and Nutritional Evaluation of Different Seed Flours as Novel Sources of Protein. World J. Dairy food Sci. 2012, 7, 59-65.

120. Araújo, A.C.M.A.; Menezes, E.G.T.; Terra, A.W.C.; Dias, B.O.; De Oliveira, É.R.; Queiroz, F. Bioactive compounds and chemical composition of Brazilian Cerrado fruits' wastes: Pequi almonds, murici, and sweet passionfruit seeds. Food Sci. Technol. 2018, 38, 203-214. [CrossRef]

121. Kruczek, M.; Drygaś, B.; Habryka, C. Pomace in fruit industry and their contemporary potential application. World Sci. News 2016, 48, 259-265.

122. Gouw, V.P.; Jung, J.; Zhao, Y. Functional properties, bioactive compounds, and in vitro gastrointestinal digestion study of dried fruit pomace powders as functional food ingredients. LWT Food Sci. Technol. 2017, 80, 136-144. [CrossRef] 
123. Castro Sousa, E.; Maria, A.; Uchôa-Thomaz, A.; Osvaldo, J.; Carioca, B.; Maia De Morais, S.; De Lima, A.; Martins, C.G.; Alexandrino, C.D.; Augusto, P.; et al. Chemical composition and bioactive compounds of grape pomace (Vitis vinifera L.), Benitaka variety, grown in the semiarid region of Northeast Brazil. Food Sci. Technol. Camp. 2014, 34, 135-142. [CrossRef]

124. Grande, L.; Dolino, O.; Montecastro, D.B.; Basilio, A.M.; Ph, A.E. Low-cost Recovery of Bromelain Solids from Industrial Pineapple Peel, Pulp, and Core Wastes Using Ethanolic Cashew Leaf Polyphenol. Philipp. J. Sci. 2020, 149, 581-587.

125. Ramli, A.N.M.; Aznan, T.N.T.; Illias, R.M. Bromelain: from production to commercialisation. J. Sci. Food Agric. 2017, 97, 1386-1395. [CrossRef] [PubMed]

126. Martins, B.C.; Rescolino, R.; Coelho, D.F.; Zanchetta, B.; Tambourgi, E.B.; Silveira, E. Characterization of Bromelain from Ananas Comosus Agroindustrial Residues Purified by Ethanol Factional Precipitation. Chem. Eng. Trans. 2014, 37, 781-786. [CrossRef]

127. Pavan, R.; Jain, S.; Kumar, A. Properties and Therapeutic Application of Bromelain: A Review. Biotechnol. Res. Int. 2012, 2012, 1-6. [CrossRef]

128. Rai, S.F.; Abu-Ghannam, D.K. Apple pomace as a potential ingredient for the development of new functional foods. Int. J. Food Sci. Technol. 2014, 49, 1743-1750.

129. Mahmoud, A.E.; Omer, H.A.; Mohammed, A.T.; Ali, M.M. Enhancement of Chemical Composition and Nutritive Value of Some Fruits Pomace by Solid State Fermentation. Egypt. J. Chem 2020, 63, 3713-3720. [CrossRef]

130. Del Valle, M.; Cámara, M.; Torija, M.E. Chemical characterization of tomato pomace. J. Sci. Food Agric. 2006, 86, 1232-1236. [CrossRef]

131. Pag An, J.; Ibarz, A. Extraction and rheological properties of pectin from fresh peach pomace. J. Food Eng. 1999, 39, 193-201. [CrossRef]

132. Elena, M.; Pardo, S.; Ramos Cassellis, E.; Escobedo, R.M.; García, E.J. Chemical Characterisation of the Industrial Residues of the Pineapple (Ananas comosus). J. Agric. Chem. Environ. 2014, 3, 53-56. [CrossRef]

133. Sharma, K.D.; Karki, S.; Thakur, N.S.; Attri, S. Chemical composition, functional properties and processing of carrot-A review. J. Food Sci. Technol. 2012, 49, 22-32. [CrossRef]

134. Chandrasekara, A.; Josheph Kumar, T. Roots and tuber crops as functional foods: A review on phytochemical constituents and their potential health benefits. Int. J. Food Sci. 2016, 2016, 15. [CrossRef]

135. Aprianita, A.; Vasiljevic, T.; Bannikova, A.; Kasapis, S. Physicochemical properties of flours and starches derived from traditional Indonesian tubers and roots. J. Food Sci. Technol. 2014, 51, 3669-3679. [CrossRef]

136. Renub Research. Cassava Starch Market, Consumption \& Global Forecast, by Region, Applications and Companies. 2018. Available online: https:/ / www.researchandmarkets.com/research/kk27xb/global_cassava?w=4 (accessed on 13 December 2020).

137. Birch, P.R.J.; Bryan, G.; Fenton, B.; Gilroy, E.M.; Hein, I.; Jones, J.T.; Prashar, A.; Taylor, M.A.; Torrance, L.; Toth, I.K. Crops that feed the world 8: Potato: Are the trends of increased global production sustainable? Food Secur. 2012, 4, 477-508. [CrossRef]

138. Ferraro, V.; Piccirillo, C.; Tomlins, K.; Pintado, M.E. Cassava (Manihot esculenta Crantz) and Yam (Dioscorea spp.) Crops and Their Derived Foodstuffs: Safety, Security and Nutritional Value. Crit. Rev. Food Sci. Nutr. 2016, 56, 2714-2727. [CrossRef]

139. Laycock, B.G.; Halley, P.J. Starch Applications: State of Market and New Trends. In Starch Polymers: From Genetic Engineering to Green Applications; Elsevier: Amsterdam, The Netherlands, 2014; pp. 381-419, ISBN 9780444537300.

140. Omohimi, C.; Piccirillo, C.; Ferraro, V.; Roriz, M.C.; Omemu, M.A.; Santos, S.M.D.; Da Ressurreição, S.; Abayomi, L.; Adebowale, A.; Vasconcelos, M.W.; et al. Safety of Yam-Derived (Dioscorea rotundata) Foodstuffs-Chips, Flakes and Flour: Effect of Processing and Post-Processing Conditions. Foods 2019, 8, 12. [CrossRef]

141. Luís, J.; Soto, M.; Venegas González, J.; Bernardino Nicanor, A.; González Cruz, L.; Fernández, J.Y. Chemical Characterization and Nutritional Evaluation of Mountain's yam (Dioscorea remotiflora Kunth) Tubers. Adv. Biores 2014, 5, 153-160. [CrossRef]

142. Fakir, M.; Jannat, M.; Mostafa, M.; Seal, H. Starch and flour extraction and nutrient composition of tuber in seven cassava accessions. J. Bangladesh Agric. Univ. 2013, 10, 217-222. [CrossRef]

143. Sharma, H.K.; Njintang, N.Y.; Singhal, R.S.; Kaushal, P. Tropical Roots and Tubers; Sharma, H.K., Njintang, N.Y., Singhal, R.S., Kaushal, P., Eds.; John Wiley \& Sons, Ltd: Chichester, UK, 2016; ISBN 9781118992739.

144. Mohamad Yazid, N.S.; Abdullah, N.; Muhammad, N.; Matias-Peralta, H.M. Application of Starch and Starch-Based Products in Food Industry. J. Sci. Technol. Spec. Issue Appl. Sci. Math. 2018, 10, 144-174. [CrossRef]

145. IMARC Group. Cassava Starch Market: Global Industry Trends, Share, Size, Growth, Opportunity and Forecast $2019-2024$. 2019. Available online: https:/ / www.researchandmarkets.com/reports/4752275/cassava-starch-market-global-industry-trends (accessed on 13 December 2020).

146. Beltrán-Penagos, M.A.; Sánchez-Camargo, A.D.; Narvaez-Cuenca, C.E. Proximal composition, bioactive compounds and biorefinery approach in potato tubers of Solanum tuberosum Group Phureja: a review. Int. J. Food Sci. Technol. 2020, 55, 2282-2295. [CrossRef]

147. Liang, S.; McDonald, A.G. Chemical and thermal characterization of potato peel waste and its fermentation residue as potential resources for biofuel and bioproducts production. J. Agric. Food Chem. 2014, 62, 8421-8429. [CrossRef] [PubMed]

148. Somendrika, M.A.D.; Wickramasinghe, I.; Wansapala, M.A.J.; Peiris, S. Sensory Profile, Nutritional and Shelf-Life Analysis of Cassava Par-Fried Frozen Slices Developed with Raw Cassava Roots. Vidyodaya J. Sci. 2019, 22, 43-52.

149. Sepelev, I.; Galoburda, R. Industrial potato peel waste application in food production: A review. Investig. para Desarro. Rural 2015, 1, 130-136.

150. Florencia, V.; López, O.V.; García, M.A. Exploitation of by-products from cassava and ahipa starch extraction as filler of thermoplastic corn starch. Compos. Part B Eng. 2020, 182, 107653. [CrossRef] 
151. Zhang, M.; Xie, L.; Yin, Z.; Khanal, S.K.; Zhou, Q. Biorefinery approach for cassava-based industrial wastes: Current status and opportunities. Bioresour. Technol. 2016, 215, 50-62. [CrossRef]

152. Kleekayai, T.; Suntornsuk, W. Production and characterization of chitosan obtained from Rhizopus oryzae grown on potato chip processing waste. World J. Microbiol. Biotechnol. 2011, 27, 1145-1154. [CrossRef]

153. Abedini, A.; Amiri, H.; Karimi, K. Efficient biobutanol production from potato peel wastes by separate and simultaneous inhibitors removal and pretreatment. Renew. Energy 2020, 160, 269-277. [CrossRef]

154. Albis, A.; Martínez, J.; Severiche, M.; Garcia, J. Remoción de plomo de soluciones acuosas usando cáscara de yuca modificada con ácido cítrico. Av. Investig. Ing. 2016, 13. [CrossRef]

155. Rahman, A.H.M.M.; Akter, M. Euphorbiaceae (Spurge) Family of Rajshahi, Bangladesh. Res. Plant Sci. 2013, 1, 74-80. [CrossRef]

156. Faezah, O.N.; Aishah, H.; Kalsom, Y. Umi Comparative evaluation of organic and inorganic fertilizers on total phenolic, total flavonoid, antioxidant activity and cyanogenic glycosides in cassava (Manihot esculenta). Afr. J. Biotechnol. 2016, 12, $2414-2421$.

157. Chaves-López, C.; Serio, A.; Grande-Tovar, C.D.; Cuervo-Mulet, R.; Delgado-Ospina, J.; Paparella, A. Traditional Fermented Foods and Beverages from a Microbiological and Nutritional Perspective: The Colombian Heritage. Compr. Rev. Food Sci. Food Saf. 2014, 13, 1031-1048. [CrossRef]

158. Daud, Z.; Sari, A.; Kassim, M.; Aripin, A.M.; Awang, H.; Zainuri, M.; Hatta, M. Chemical Composition and Morphological of Cocoa Pod Husks and Cassava Peels for Pulp and Paper Production. Aust. J. Basic Appl. Sci. 2013, 7, 406-411.

159. Akinyele, B.J.; Akinyosoye, F.A. Effect of Volvariella volvacea cultivaton on the chemical composition of agrowastes. Afr. J. Biotechnol. 2005, 4, 979-983. [CrossRef]

160. Aruna, T.E.; Aworh, O.C.; Raji, A.O.; Olagunju, A.I. Protein enrichment of yam peels by fermentation with Saccharomyces cerevisiae (BY4743). Ann. Agric. Sci. 2017, 62, 33-37. [CrossRef]

161. Arapoglou, D.; Varzakas, T.; Vlyssides, A.; Israilides, C. Ethanol production from potato peel waste (PPW). Waste Manag. 2010. [CrossRef]

162. Sun, Y.; Yang, G.; Zhang, L.; Sun, Z. Preparation of high performance H2S removal biochar by direct fluidized bed carbonization using potato peel waste. Process Saf. Environ. Prot. 2017, 107, 281-288. [CrossRef]

163. de Fatima Araújo, L.; Felix, R.A.A.R.; Aguiar, E.M.; Coelho, R.R.P. Evaluation of the Potentiality of Maniocresidues (Manihot esculenta Crantz) in animal feeding. Int. J. Adv. Eng. Res. Sci. 2020, 7, 305-308. [CrossRef]

164. Travalini, A.P.; Lamsal, B.; Magalhães, W.L.E.; Demiate, I.M. Cassava starch films reinforced with lignocellulose nanofibers from cassava bagasse. Int. J. Biol. Macromol. 2019, 139, 1151-1161. [CrossRef] [PubMed]

165. Wongskeo, P.; Rangsunvigit, P.; Chavadej, S. Production of Glucose from the Hydrolysis of Cassava Residue using Bacteria Isolates from Thai Higher Termites. World Acad. Sci. Eng. Technol. 2012, 6, 275-278.

166. Koehler, P.; Wieser, H. Chemistry of cereal grains. In Handbook on Sourdough Biotechnology; Springer: Berlin/Heidelberg, Germany, 2013; pp. 11-45, ISBN 9781461454250.

167. Margier, M.; Georgé, S.; Hafnaoui, N.; Remond, D.; Nowicki, M.; Du Chaffaut, L.; Amiot, M.-J.; Reboul, E. Nutritional Composition and Bioactive Content of Legumes: Characterization of Pulses Frequently Consumed in France and Effect of the Cooking Method. Nutrients 2018, 10, 1668. [CrossRef] [PubMed]

168. Albuquerque, T.G.; Nunes, M.A.; Bessada, S.M.F.; Costa, H.S.; Oliveira, M.B.P.P. Biologically active and health promoting food components of nuts, oilseeds, fruits, vegetables, cereals, and legumes. In Chemical Analysis of Food; Elsevier: Amsterdam, The Netherlands, 2020; pp. 609-656.

169. Campos-Vega, R.; Nieto-Figueroa, K.H.; Oomah, B.D. Cocoa (Theobroma cacao L.) pod husk: Renewable source of bioactive compounds. Trends Food Sci. Technol. 2018, 81, 172-184. [CrossRef]

170. Etxeberria, U.; De La Garza, A.L.; Campin, J.; Martnez, J.A.; Milagro, F.I. Antidiabetic effects of natural plant extracts via inhibition of carbohydrate hydrolysis enzymes with emphasis on pancreatic alpha amylase. Expert Opin. Ther. Targets 2012, 16, 269-297. [CrossRef] [PubMed]

171. Pegels, N.; González, I.; García, T.; Martín, R. Authenticity testing of wheat, barley, rye and oats in food and feed market samples by real-time PCR assays. LWT Food Sci. Technol. 2015, 60, 867-875. [CrossRef]

172. OCDE/FAO Cereales. Perspectivas Agricolas 2017-2026; OECD Publishing: Paris, Franch, 2017.

173. Galati, A.; Oguntoyinbo, F.A.; Moschetti, G.; Crescimanno, M.; Settanni, L. The Cereal Market and the Role of Fermentation in Cereal-Based Food Production in Africa. Food Rev. Int. 2014, 30, 317-337. [CrossRef]

174. Sudheesh, S.; Verma, P.; Forster, J.; Cogan, N.; Kaur, S. Generation and Characterisation of a Reference Transcriptome for Lentil (Lens culinaris Medik.). Int. J. Mol. Sci. 2016, 17, 1887. [CrossRef]

175. Singh, J.; Kanaujia, R.; Kumar, J.; Singh, F.; Ak, S.; Singh, N.P. Genetic Variability for Antioxidant Activity and Total Phenolic Content in Four Major Pulse crops. Tech. Nutr. Food Sci. 2018, 1, 1-6. [CrossRef]

176. Śmiglak-Krajewska, M.; Wojciechowska-Solis, J.; Viti, D. Consumers' Purchasing Intentions on the Legume Market as Evidence of Sustainable Behaviour. Agriculture 2020, 10, 424. [CrossRef]

177. Duodu, K.G. Effects of processing on antioxidant phenolics of cereal and legume grains. In Advances in Cereal Science: Implications to Food Processing and Health Promotion; American Chemical Society: Washington, DC, USA, 2011; Volume 1089, pp. 31-54.

178. Oghbaei, M.; Prakash, J. Effect of primary processing of cereals and legumes on its nutritional quality: A comprehensive review. Cogent Food Agric. 2016, 2, 1136015. [CrossRef] 
179. Akanbi, T.O.; Dare, K.O.; Aryee, A.N.A. High-Value Products from Cereal, Nuts, Fruits, and Vegetables Wastes. In Byproducts from Agriculture and Fisheries; Wiley: Hoboken, NJ, USA, 2019; pp. 347-368.

180. Branca, C.; Di Blasi, C.; Galgano, A. Pyrolytic conversion of wastes from cereal, protein and oil-protein crops. J. Anal. Appl. Pyrolysis 2017, 127, 426-435. [CrossRef]

181. Arendt, E.; Zannini, E. Cereal Grains for the Food and Beverage Industries; Elsevier: Amsterdam, The Netherlands, 2013.

182. Owens, G. Cereals Processing Technology; CRC Press: Boca Raton, FL, USA, 2001.

183. Franzen, M.; Borgerhoff Mulder, M. Ecological, economic and social perspectives on cocoa production worldwide. Biodivers. Conserv. 2007, 16, 3835-3849. [CrossRef]

184. Afoakwa, E. Cocoa Production and Processing Technology; CRC Press: Boca Raton, FL, USA, 2014.

185. Beg, M.S.; Ahmad, S.; Jan, K.; Bashir, K. Status, supply chain and processing of cocoa-A review. Trends Food Sci. Technol. 2017, 66, 108-116. [CrossRef]

186. Du, Y.; Jiang, X.; Lv, G.; Li, X.; Chi, Y.; Yan, J.; Liu, X.; Buekens, A. TG-pyrolysis and FTIR analysis of chocolate and biomass waste. J. Therm. Anal. Calorim. 2014, 117, 343-353. [CrossRef]

187. Gutiérrez, T.J. State-of-the-Art Chocolate Manufacture: A Review. Compr. Rev. Food Sci. Food Saf. 2017, 16, 1313-1344. [CrossRef]

188. Langridge, P. Economic and Academic Importance of Barley. In The Barley Genome; Springer: Chambridge, UK, 2018; pp. 1-10.

189. Giraldo, P.; Benavente, E.; Manzano-Agugliaro, F.; Gimenez, E. Worldwide Research Trends on Wheat and Barley: A Bibliometric Comparative Analysis. Agronomy 2019, 9, 352. [CrossRef]

190. Rodman, A.D.; Gerogiorgis, D.I. Multi-objective process optimisation of beer fermentation via dynamic simulation. Food Bioprod. Process. 2016, 100, 255-274. [CrossRef]

191. Loomis, G.; Dari, B.; Rogers, C.W.; Sihi, D. Evaluation of residue management practices on barley residue decomposition. PLoS ONE 2020, 15, e0232896. [CrossRef]

192. Martínez, M.L.; Eliche, D.; Cruz, N.; Corpas, F.A. Utilization of bagasse from the beer industry in clay brick production for building. Materconstrucc. Revistas. Csic. 2012, 62, 465-2746. [CrossRef]

193. Bustamante, M.; Fernández-Gil, M.; Churruca, I.; Miranda, J.; Lasa, A.; Navarro, V.; Simón, E. Evolution of Gluten Content in Cereal-Based Gluten-Free Products: An Overview from 1998 to 2016. Nutrients 2017, 9, 21. [CrossRef] [PubMed]

194. Li, Y.; Jin, Y.; Borrion, A.; Li, H. Current status of food waste generation and management in China. Bioresour. Technol. 2019, 273, 654-665. [CrossRef] [PubMed]

195. Satusap, P.; Chavasit, V.; Kriengsinyos, W.; Judprasong, K. Development of cereal and legume based food products for the elderly. Springerplus 2014, 3, 1-8. [CrossRef] [PubMed]

196. Awarikabey, E.; Amponsah, I.K.; Woode, M.Y. The value of the cocoa bean shell (hull) and the effect of various processing methods on the phyto-constituents and antioxidant activity of the nib and shell. J. Nat. Prod. Plant Resour. 2014, 4, 58-64.

197. Ramachandran, S.; Singh, K.; Larroche, C.; Soccol, C.R.; Pandey, A. Oil cakes and their biotechnological applications-A review. Bioresour. Technol. 2007, 98. [CrossRef] [PubMed]

198. Demir, H.; Tari, C. Valorization of wheat bran for the production of polygalacturonase in SSF of Aspergillus sojae. Ind. Crop. Prod. 2014, 54, 302-309. [CrossRef]

199. Rosentrater, K.A. A review of corn masa processing residues: Generation, properties, and potential utilization. Waste Manag. 2006, 26, 284-292. [CrossRef]

200. Alexandri, M.; López-Gómez, J.P.; Olszewska-Widdrat, A.; Venus, J. Valorising agro-industrial wastes within the circular bioeconomy concept: The case of defatted rice bran with emphasis on bioconversion strategies. Fermentation 2020, 6, 42. [CrossRef]

201. Tassoni, A.; Tedeschi, T.; Zurlini, C.; Cigognini, I.M.; Petrusan, J.-I.; Rodríguez, Ó.; Neri, S.; Celli, A.; Sisti, L.; Cinelli, P.; et al. State-of-the-Art Production Chains for Peas, Beans and Chickpeas-Valorization of Agro-Industrial Residues and Applications of Derived Extracts. Molecules 2020, 25, 1383. [CrossRef]

202. Magistrelli, D.; Zanchi, R.; Malagutti, L.; Galassi, G.; Canzi, E.; Rosi, F. Effects of Cocoa Husk Feeding on the Composition of Swine 2 Intestinal Microbiota. J. Agric. Food Chem. 2016, 64, 2046-2052. [CrossRef]

203. Mendes, C.A.; Adnet, F.A.; Leite, M.C.; Furtado, C.G.; Sousa, A.M. Chemical, physical, mechanical, thermal and morphological characteriz.ation of corn husk residue. Cellul. Chem. Technol. 2015, 49, 727-735.

204. Bledzki, A.K.; Mamun, A.A.; Volk, J. Physical, chemical and surface properties of wheat husk, rye husk and soft wood and their polypropylene composites. Compos. Part A Appl. Sci. Manuf. 2010, 41, 480-488. [CrossRef]

205. Aruwayo, A. Chemical composition of some selected non-conventional feed resources katsina. In Proceedings of the Asian-Nias Joint Annual Meeting, Abuja, Nigeria, 1-4 November 2020.

206. Hansen, M.J.; Chwalibog, A.; Tauson, A.-H. Influence of different fibre sources in diets for growing pigs on chemical composition of faeces and slurry and ammonia emission from slurry. Anim. Feed Sci. Technol. 2007, 134, 326-336. [CrossRef]

207. Barana, D.; Salanti, A.; Orlandi, M.; Danish Ali, S.; Ali, D.S.; Zoia, L. Biorefinery process for the simultaneous recovery of lignin, hemicelluloses, cellulose nanocrystals and silica from rice husk and Arundo donax. Ind. Crop. Prod. 2016. [CrossRef]

208. Oomah, B.D.; Corbé, A.; Balasubramanian, P. Antioxidant and Anti-inflammatory Activities of Bean (Phaseolus vulgaris L.) Hulls. J. Agric. Food Chem 2010, 58, 8225-8230. [CrossRef]

209. Hussain, S.; Jõudu, I.; Bhat, R. Dietary fiber from underutilized plant resources-A positive approach for valorization of fruit and vegetable wastes. Sustainablity 2020, 12, 5401. [CrossRef] 
210. Schmitz, E.; Nordberg Karlsson, E.; Adlercreutz, P. Warming weather changes the chemical composition of oat hulls. Plant Biol. 2020, 22, 1086-1091. [CrossRef]

211. Mello, L.R.P.F.; Mali, S. Use of malt bagasse to produce biodegradable baked foams made from cassava starch. Ind. Crop. Prod. 2014, 55, 187-193. [CrossRef]

212. dos Santos Mathias, T.R.; de Mello, P.P.; Servulo1, E.F.C. Solid wastes in brewing process: A review. J. Brew. Distill. 2014, 5, 1-9. [CrossRef]

213. Franciski, M.A.; Peres, E.C.; Godinho, M.; Perondi, D.; Foletto, E.L.; Collazzo, G.C.; Dotto, G.L. Development of CO2 activated biochar from solid wastes of a beer industry and its application for methylene blue adsorption. Waste Manag. 2018, 78, 630-638. [CrossRef]

214. Woyengo, T.A.; Patterson, R.; Levesque, C.L. Nutritive value of extruded or multi-enzyme supplemented cold-pressed soybean cake for pigs. J. Anim. Sci. 2016, 94, 5230-5238. [CrossRef]

215. Tyapkova, O.; Osen, R.; Wagenstaller, M.; Baier, B.; Specht, F.; Zacherl, C. Replacing fishmeal with oilseed cakes in fish feed-A study on the influence of processing parameters on the extrusion behavior and quality properties of the feed pellets. J. Food Eng. 2016, 191, 28-36. [CrossRef]

216. Ancuța, P.; Sonia, A. Oil Press-Cakes and Meals Valorization through Circular Economy Approaches: A Review. Appl. Sci. 2020, 10, 7432. [CrossRef]

217. Otles, S.; Despoudi, S.; Bucatariu, C.; Kartal, C. Food waste management, valorization, and sustainability in the food industry. In Food Waste Recovery: Processing Technologies and Industrial Techniques; Elsevier Inc.: Amsterdam, The Netherlands, 2015; pp. 3-23, ISBN 9780128004197.

218. Campos, D.A.; Gómez-García, R.; Vilas-Boas, A.A.; Madureira, A.R.; Pintado, M.M. Management of Fruit Industrial By-ProductsA Case Study on Circular Economy Approach. Molecules 2020, 25, 320. [CrossRef] [PubMed]

219. Ravindran, R.; Jaiswal, A.K. Exploitation of Food Industry Waste for High-Value Products. Trends Biotechnol. 2016, 34, 58-69. [CrossRef] [PubMed]

220. Kibler, K.M.; Reinhart, D.; Hawkins, C.; Motlagh, A.M.; Wright, J. Food waste and the food-energy-water nexus: A review of food waste management alternatives. Waste Manag. 2018, 74, 52-62. [CrossRef]

221. Strazza, C.; Magrassi, F.; Gallo, M.; Del Borghi, A. Life Cycle Assessment from food to food: A case study of circular economy from cruise ships to aquaculture. Sustain. Prod. Consum. 2015, 2, 40-51. [CrossRef]

222. Zeković, I.; Lenhardt, L.; Dramićanin, T.; Dramićanin, M.D. Classification of Intact Cereal Flours by Front-Face Synchronous Fluorescence Spectroscopy. Food Anal. Methods 2012, 5, 1205-1213. [CrossRef]

223. Sciarini, L.S.; Ribotta, P.D.; León, A.E.; Pérez, G.T. Incorporation of several additives into gluten free breads: Effect on dough properties and bread quality. J. Food Eng. 2012, 111, 590-597. [CrossRef]

224. CARLSON, B.L.; KNORR, D.; Watkins, T.R. Influence of Tomato Seed Addition on the Quality of Wheat Flour Breads. J. Food Sci. 1981, 46, 1029-1031. [CrossRef]

225. Iuga, M.; Mironeasa, S. Potential of grape byproducts as functional ingredients in baked goods and pasta. Compr. Rev. Food Sci. Food Saf. 2020, 19, 2473-2505. [CrossRef] [PubMed]

226. Tiwari, B.K.; Brennan, C.S.; Jaganmohan, R.; Surabi, A.; Alagusundaram, K. Utilisation of pigeon pea (Cajanus cajan L) byproducts in biscuit manufacture. LWT Food Sci. Technol. 2011, 44, 1533-1537. [CrossRef]

227. Sainz, R.L.; Szezecinski, A.C.S.F.; Fontana, M.; Bosenbecker, V.K.; Ferri, V.C.; do Nascimento, C.O. Uso de harina de baya de uva en la producción de cookies. BIO Web Conf. 2019, 12, 04003. [CrossRef]

228. Pitre, A.M.; Andrade, A.; García, L.; Londoño, P. Desarrollo de una galleta a partir del orujo de uva variedad criolla negra. Anales 2011, 11, 191-205.

229. Koca, I.; Tekguler, B.; Yilmaz, V.A.; Hasbay, I.; Koca, A.F. The use of grape, pomegranate and rosehip seed flours in Turkish noodle (erişte) production. J. Food Process. Preserv. 2018, 42. [CrossRef]

230. Masli, M.D.P.; Gu, B.J.; Rasco, B.A.; Ganjyal, G.M. Fiber-Rich Food Processing Byproducts Enhance the Expansion of Cornstarch Extrudates. J. Food Sci. 2018, 83, 2500-2510. [CrossRef]

231. Ying, D.Y.; Hlaing, M.M.; Lerisson, J.; Pitts, K.; Cheng, L.; Sanguansri, L.; Augustin, M.A. Physical properties and FTIR analysis of rice-oat flour and maize-oat flour based extruded food products containing olive pomace. Food Res. Int. 2017, 100, 665-673. [CrossRef]

232. Lohani, U.C.; Muthukumarappan, K. Effect of Extrusion Processing Parameters on Antioxidant, Textural and Functional Properties of Hydrodynamic Cavitated Corn Flour, Sorghum Flour and Apple Pomace-Based Extrudates. J. Food Process Eng. 2017, 40. [CrossRef]

233. Aparecida Damasceno, K.; Alvarenga Gonçalves, C.A.; Dos Santos Pereira, G.; Lacerda Costa, L.; Bastianello Campagnol, P.C.; Leal De Almeida, P.; Arantes-Pereira, L. Development of Cereal Bars Containing Pineapple Peel Flour (Ananas comosus L. Merril). J. Food Qual. 2016, 39, 417-424. [CrossRef]

234. Rosales Soto, M.U.; Brown, K.; Ross, C.F. Antioxidant activity and consumer acceptance of grape seed flour-containing food products. Int. J. Food Sci. Technol. 2012, 47, 592-602. [CrossRef]

235. Wani, A.A.; Sogi, D.S.; Singh, P.; Khatkar, B.S. Influence of watermelon seed protein concentrates on dough handling, textural and sensory properties of cookies. J. Food Sci. Technol. 2015, 52, 2139-2147. [CrossRef] 
236. MarketsandMarkets. Natural Food Colors \& Flavors Market by Color Type (Caramel, Carotenoids, Anthocyanins, Curcumin, Annatto, and Copper Chlorophyllin), Flavor Type (Natural Extracts, Aroma Chemicals, \& Essential Oils), Application \& RegionGlobal Forecast to 2025. 2020. Available online: https:/ / www.marketsandmarkets.com/Market-Reports/natural-colors-flavorsmarket-676.html (accessed on 13 December 2020).

237. Mordor Intelligence. Global Food Colorants Market, Growth, Trends, Forecast. 2020. Available online: https://www. mordorintelligence.com/industry-reports/food-colorants-market (accessed on 13 December 2020).

238. Rodriguez-Amaya, D.B. Natural food pigments and colorants. Curr. Opin. Food Sci. 2016, 7, 20-26. [CrossRef]

239. Rymbai, H.; Sharma, R.R.; Srivastav, M. Biocolorants and Its Implications in Health and Food Industry-A Review. J. Pharmacol. Res. 2011, 3, 2228-2244.

240. Koubaa, M.; Barba, F.J; Grimi, N.; Mhemdi, H.; Koubaa, W.; Boussetta, N.; Vorobiev, E. Recovery of colorants from red prickly pear peels and pulps enhanced by pulsed electric field and ultrasound. Innov. Food Sci. Emerg. Technol. 2016, 37, 336-344. [CrossRef]

241. Wang, X.; Li, D.; Shi, X. A fuzzy model for aggregative food safety risk assessment in food supply chains. Prod. Plan. Control 2012, 23, 377-395. [CrossRef]

242. Backes, E.; Pereira, C.; Barros, L.; Prieto, M.A.; Genena, A.K.; Barreiro, M.F.; Ferreira, I.C.F.R. Recovery of bioactive anthocyanin pigments from Ficus carica L. peel by heat, microwave, and ultrasound based extraction techniques. Food Res. Int. 2018, 113, 197-209. [CrossRef]

243. Parra-Campos, A.; Ordóñez-Santos, L.E. Natural pigment extraction optimization from coffee exocarp and its use as a natural dye in French meringue. Food Chem. 2019, 285, 59-66. [CrossRef]

244. Yamashita, C.; Chung, M.M.S.; dos Santos, C.; Mayer, C.R.M.; Moraes, I.C.F.; Branco, I.G. Microencapsulation of an anthocyaninrich blackberry (Rubus spp.) by-product extract by freeze-drying. LWT Food Sci. Technol. 2017, 84, 256-262. [CrossRef]

245. Mourtzinos, I.; Prodromidis, P.; Grigorakis, S.; Makris, D.P.; Biliaderis, C.G.; Moschakis, T. Natural food colorants derived from onion wastes: Application in a yoghurt product. Electrophoresis 2018, 39, 1975-1983. [CrossRef]

246. Mitrea, L.; Călinoiu, L.-F.; Martău, G.-A.; Szabo, K.; Teleky, B.-E.; Mureșan, V.; Rusu, A.-V.; Socol, C.-T.; Vodnar, D.-C. Poly(vinyl alcohol)-Based Biofilms Plasticized with Polyols and Colored with Pigments Extracted from Tomato By-Products. Polymers 2020, 12, 532. [CrossRef]

247. Rizk, E.M.; Bedier, S.H.; Elgendy, M.A. Utilization of carotenoid pigments extracted from tomato peel as natural antioxidants and colorants in sunflower oil and spaghetti. Egypt. J. Agric. Res. 2014, 92, 309-321.

248. Noronha Matos, K.A.; Praia Lima, D.; Pereira Barbosa, A.P.; Zerlotti Mercadante, A.; Campos Chisté, R. Peels of tucumã (Astrocaryum vulgare) and peach palm (Bactris gasipaes) are by-products classified as very high carotenoid sources. Food Chem. 2019, 272, 216-221. [CrossRef]

249. Kantifedaki, A.; Kachrimanidou, V.; Mallouchos, A.; Papanikolaou, S.; Koutinas, A.A. Orange processing waste valorisation for the production of bio-based pigments using the fungal strains Monascus purpureus and Penicillium purpurogenum. J. Clean. Prod. 2018, 185, 882-890. [CrossRef]

250. Hackett, M.M.; Lee, J.H.; Francis, D.; Schwartz, S.J. Thermal stability and isomerization of lycopene in tomato oleoresins from different varieties. J. Food Sci. 2004, 69, 536-541. [CrossRef]

251. Rizk, E.M.; El-Kady, A.T.; El-Bialy, A.R. Charactrization of carotenoids (lyco-red) extracted from tomato peels and its uses as natural colorants and antioxidants of ice cream. Ann. Agric. Sci. 2014, 59, 53-61. [CrossRef]

252. Li, S.; Yang, X.; Yang, S.; Zhu, M.; Structural, X.W.-C.U. Technology prospecting on enzymes: application, marketing and engineering. Comput. Struct. Biotechnol. J. 2012, 2, e201209017. [CrossRef]

253. MarketsandMarkets. Industrial Enzymes Market Growth \& Trends: Size and Share. 2020. Available online: https://www. researchandmarkets.com/reports/4520168/industrial-enzymes-market-growth-trends-and (accessed on 13 December 2020).

254. Mordor Intelligence. Food Enzymes Market—Growth, Trends and Forecasts (2020-2025). 2020. Available online: https: / /www.mordorintelligence.com/industry-reports/global-food-enzymes-market-industry (accessed on 13 December 2020).

255. Zaidi, K.; Ali, A.; Ali, S.; International, I.N.-B.U. Microbial tyrosinases: promising enzymes for pharmaceutical, food bioprocessing, and environmental industry. Biochem. Res. Int. 2014, 2, 16. [CrossRef]

256. De Lencastre Novaes, L.C.; de Carvalho Santos Ebinuma, V.; Mazzola, P.G.; Júnior, A.P. Polymer-based alternative method to extract bromelain from pineapple peel waste. Biotechnol. Appl. Biochem. 2013, 60, 527-535. [CrossRef]

257. Sarmah, N.; Revathi, D.; Sheelu, G.; Yamuna Rani, K.; Sridhar, S.; Mehtab, V.; Sumana, C. Recent advances on sources and industrial applications of lipases. Biotechnol. Prog. 2018, 34, 5-28. [CrossRef]

258. Vicente, F.A.; Lario, L.D.; Pessoa, A.; Ventura, S.P.M. Recovery of bromelain from pineapple stem residues using aqueous micellar two-phase systems with ionic liquids as co-surfactants. Process Biochem. 2016, 51, 528-534. [CrossRef]

259. Guo, J.; Miao, Z.; Wan, J.; Guo, X. Pineapple peel bromelain extraction using gemini surfactant-based reverse micelle-Role of spacer of gemini surfactant. Sep. Purif. Technol. 2018, 190, 156-164. [CrossRef]

260. Wan, J.; Guo, J.; Miao, Z.; Guo, X. Reverse micellar extraction of bromelain from pineapple peel-Effect of surfactant structure. Food Chem. 2016, 197, 450-456. [CrossRef]

261. Campos, D.A.; Coscueta, E.R.; Valetti, N.W.; Pastrana-Castro, L.M.; Teixeira, J.A.; Picó, G.A.; Pintado, M.M. Optimization of bromelain isolation from pineapple byproducts by polysaccharide complex formation. Food Hydrocoll. 2019, 87, 792-804. [CrossRef] 
262. Okino-Delgado, C.H.; Pereira, M.S.; da Silva, J.V.I.; Kharfan, D.; do Prado, D.Z.; Fleuri, L.F. Lipases obtained from orange wastes: Commercialization potential and biochemical properties of different varieties and fractions. Biotechnol. Prog. 2019, 35, e2734. [CrossRef]

263. Silveira, E.A.; Tardioli, P.W.; Farinas, C.S. Valorization of Palm Oil Industrial Waste as Feedstock for Lipase Production. Appl. Biochem. Biotechnol. 2016, 179, 558-571. [CrossRef]

264. Moftah, O.A.S.; Grbavčić, S.; Žuža, M.; Luković, N.; Bezbradica, D.; Knežević-Jugović, Z. Adding value to the oil cake as a waste from oil processing industry: Production of lipase and protease by Candida utilis in solid state fermentation. Appl. Biochem. Biotechnol. 2012, 166, 348-364. [CrossRef]

265. Pereira, A.D.S.; Fontes-Sant'Ana, G.C.; Amaral, P.F. Mango agro-industrial wastes for lipase production from Yarrowia lipolytica and the potential of the fermented solid as a biocatalyst. Food Bioprod. Process. 2019, 115, 68-77. [CrossRef]

266. Rizk, M.A.; El-Kholany, E.A.; Abo-Mosalum, E.M.R. Production of $\alpha$-amylase by Aspergillus niger isolated from mango kernel. Middle East J. Appl. Sci. 2019, 9, 134-141.

267. Yarovaya, L.; Waranuch, N.; Wisuitiprot, W.; Khunkitti, W. Effect of grape seed extract on skin fibroblasts exposed to UVA light and its photostability in sunscreen formulation. J. Cosmet. Dermatol. 2020. [CrossRef]

268. Garcia, R. Comercialization and productive internacionalization in the cosmetic industry: competitive challenges for brazilian firms. Production 2005, 15, 158-171. [CrossRef]

269. Matwiejczuk, N.; Galicka, A.; Brzóska, M.M. Review of the safety of application of cosmetic products containing parabens. J. Appl. Toxicol. 2020, 40, 176-210. [CrossRef] [PubMed]

270. Ahmad, F.; Khan, S.T. Potential industrial use of compounds from by-products of fruits and vegetables. In Health and Safety Aspects of Food Processing Technologies; Springer International Publishing: Berlin/Heidelberg, Germany, 2019; pp. 273-307, ISBN 9783030249038.

271. Herranz-López, M.; Barrajón-Catalán, E. Antioxidants and Skin Protection. Antioxidants 2020, 9, 704. [CrossRef] [PubMed]

272. Silva, S.; Ferreira, M.; Oliveira, A.S.; Magalhães, C.; Sousa, M.E.; Pinto, M.; Sousa Lobo, J.M.; Almeida, I.F. Evolution of the use of antioxidants in anti-ageing cosmetics. Int. J. Cosmet. Sci. 2019, 41, 378-386. [CrossRef] [PubMed]

273. Gabros, S.; Nessel, T.A.; Zito, P.M. Sunscreens And Photoprotection; StatPearls Publishing: Treasure Island, FL, USA, 2020.

274. Moo-Huchin, V.M.; Moo-Huchin, M.I.; Estrada-León, R.J.; Cuevas-Glory, L.; Estrada-Mota, I.A.; Ortiz-Vázquez, E.; BetancurAncona, D.; Sauri-Duch, E. Antioxidant compounds, antioxidant activity and phenolic content in peel from three tropical fruits from Yucatan, Mexico. Food Chem. 2015, 166, 17-22. [CrossRef] [PubMed]

275. Lourith, N.; Kanlayavattanakul, M.; Chingunpitak, J. Development of sunscreen products containing passion fruit seed extract. Braz. J. Pharm. Sci. 2017, 53, 16116. [CrossRef]

276. Gordobil, O.; Olaizola, P.; Banales, J.M.; Labidi, J. Lignins from Agroindustrial by-Products as Natural Ingredients for Cosmetics: Chemical Structure and In Vitro Sunscreen and Cytotoxic Activities. Molecules 2020, 25, 1131. [CrossRef]

277. Marto, J.; Gouveia, L.F.; Chiari, B.G.; Paiva, A.; Isaac, V.; Pinto, P.; Simões, P.; Almeida, A.J.; Ribeiro, H.M. The green generation of sunscreens: Using coffee industrial sub-products. Ind. Crop. Prod. 2016, 80, 93-100. [CrossRef]

278. Milani, L.P.G.; Garcia, N.O.S.; Morais, M.C.; Dias, A.L.S.; Oliveira, N.L.; Conceição, E.C. Extract from byproduct Psidium guajava standardized in ellagic acid: additivation of the in vitro photoprotective efficacy of a cosmetic formulation. Rev. Bras. Farmacogn. 2018, 28, 692-696. [CrossRef]

279. Yarovaya, L.; Khunkitti, W. Anti-inflammatory activity of grape seed extract as a natural sun protection enhancer for broadspectrum sunscreen. In Proceedings of the Cosmetic \& Beauty International Conference 2019 Sustainable Cosmetic \& Beauty Innovations; Mae Fa Luang University, Chiang Rai, Thailand, 7-9 October 2019.

280. Mota, M.D.; da Boa Morte, A.N.; Silva, L.C.R.C.; Chinalia, F.A. Sunscreen protection factor enhancement through supplementation with Rambutan (Nephelium lappaceum L) ethanolic extract. J. Photochem. Photobiol. B Biol. 2020, 205, 111837. [CrossRef]

281. De Lima Yamaguchi, K.K.; Dos, L.; Santarém, S.; Lamarão, C.V.; Lima, E.S.; Florêncio Da Veiga-Junior, V. Avaliação in vitro da Atividade Fotoprotetora de Resíduos de Frutas Amazônicas. Sci. Amaz. 2016, 5, 109-116.

282. Fair, R.J.; Tor, Y. Antibiotics and Bacterial Resistance in the 21st Century. Perspect. Medicin. Chem. 2014, 6. [CrossRef]

283. MarketsandMarkets. Healthcare BPO Market-Global Forecasts to 2022 I by Outsourcing Approaches, Pharmaceutical, Provider \& Models I MarketsandMarkets. 2017. Available online: https:/ / www.marketsandmarkets.com/Market-Reports/healthcareoutsourcing-bpo-market-472.html (accessed on 13 December 2020).

284. IQVIA. The Global Use of Medicine in 2019 and Outlook to 2023. 2019. Available online: https:/ / www.iqvia.com/insights/theiqvia-institute/reports/the-global-use-of-medicine-in-2019-and-outlook-to-2023 (accessed on 13 December 2020).

285. Aminov, R. History of antimicrobial drug discovery: Major classes and health impact. Biochem. Pharmacol. 2017, 133, 4-19. [CrossRef] [PubMed]

286. Kardan Yamchi, J.; Haeili, M.; Gizaw Feyisa, S.; Kazemian, H.; Hashemi Shahraki, A.; Zahednamazi, F.; Imani Fooladi, A.A.; Feizabadi, M.M. Evaluation of efflux pump gene expression among drug susceptible and drug resistant strains of Mycobacterium tuberculosis from Iran. Infect. Genet. Evol. 2015, 36, 23-26. [CrossRef] [PubMed]

287. Peanparkdee, M.; Iwamoto, S. Bioactive compounds from by-products of rice cultivation and rice processing: Extraction and application in the food and pharmaceutical industries. Trends Food Sci. Technol. 2019, 86, 109-117. [CrossRef] 
288. Meneguzzo, F.; Ciriminna, R.; Zabini, F.; Pagliaro, M. Review of evidence available on hesperidin-rich products as potential tools against COVID-19 and hydrodynamic cavitation-based extraction as a method of increasing their production. Processes 2020, 8 , 549. [CrossRef]

289. Ademosun, A.O.; Oboh, G.; Passamonti, S.; Tramer, F.; Ziberna, L.; Boligon, A.A.; Athayde, M.L. Phenolic composition of orange peels and modulation of redox status and matrix metalloproteinase activities in primary (Caco-2) and metastatic (LoVo and LoVo/ADR) colon cancer cells. Eur. Food Res. Technol. 2016, 242, 1949-1959. [CrossRef]

290. Churata-Oroya, D.E.; Ramos-Perfecto, D.; Moromi-Nakata, H.; Martínez-Cadillo, E.; Castro-Luna, A.; Garcia, R. Antifungal Eff ect of Citrus paradisi "grapefruit" on strains of Candida albicans isolated from patients with denture stomatitis. Rev Estomatol Hered. 2016, 26, 78-84. [CrossRef]

291. Giacometti, J.; Bursać Kovačević, D.; Putnik, P.; Gabrić, D.; Bilušić, T.; Krešić, G.; Stulić, V.; Barba, F.J.; Chemat, F.; Barbosa-Cánovas, G.; et al. Extraction of bioactive compounds and essential oils from mediterranean herbs by conventional and green innovative techniques: A review. Food Res. Int. 2018, 113, 245-262. [CrossRef]

292. De la Rosa, J.P.; Ruiz-Palomino, P.; Arriola-Guevara, E.; García-Fajardo, J.; Sandoval, G.; Guatemala-Morales, G. A Green Process for the Extraction and Purification of Hesperidin from Mexican Lime Peel (Citrus aurantifolia Swingle) that is Extendible to the Citrus Genus. Processes 2018, 6, 266. [CrossRef]

293. Hilali, S.; Fabiano-Tixier, A.-S.; Ruiz, K.; Hejjaj, A.; Ait Nouh, F.; Idlimam, A.; Bily, A.; Mandi, L.; Chemat, F. Green Extraction of Essential Oils, Polyphenols, and Pectins from Orange Peel Employing Solar Energy: Toward a Zero-Waste Biorefinery. ACS Sustain. Chem. Eng. 2019, 7, 11815-11822. [CrossRef]

294. Meneguzzo, F.; Brunetti, C.; Fidalgo, A.; Ciriminna, R.; Delisi, R.; Albanese, L.; Zabini, F.; Gori, A.; Beatriz, L.; Nascimento, S.; et al. Real-Scale Integral Valorization of Waste Orange Peel via Hydrodynamic Cavitation. Processes 2019, 7, 581. [CrossRef]

295. Albanese, L.; Meneguzzo, F. Hydrodynamic cavitation technologies: A pathway to more sustainable, healthier beverages, and food supply chains. In Processing and Sustainability of Beverages; Elsevier: Amsterdam, The Netherlands, 2019.

296. Xu, D.-P.; Zheng, J.; Zhou, Y.; Li, Y.; Li, S.; Li, H.-B. Extraction of Natural Antioxidants from the Thelephora ganbajun Mushroom by an Ultrasound-Assisted Extraction Technique and Evaluation of Antiproliferative Activity of the Extract against Human Cancer Cells. Int. J. Mol. Sci. 2016, 17, 1664. [CrossRef] [PubMed]

297. Roy, S.; Lingampeta, P. Solid wastes of fruit peels as source of low cost broad spectrum natural antimicrobial compoundsFuranone, Furfural and Benezenetriol. Int. J. Res. Eng. Technol. 2014, 3, 2321-7308.

298. Santos, T.R.J.; de Aquino Santana, L.C.L. Antimicrobial potential of exotic fruits residues. S. Afr. J. Bot. 2019, 124, 338-344. [CrossRef]

299. Ademosun, A.O.; Oboh, G.; Passamonti, S.; Tramer, F.; Ziberna, L.; Boligon, A.A.; Athayde, M.L. Inhibition of metalloproteinase and proteasome activities in colon cancer cells by citrus peel extracts. J. Basic Clin. Physiol. Pharmacol. 2015, 26, 471-477. [CrossRef] [PubMed]

300. Meiyanto, E.; Hermawan, A. Anindyajati Natural products for cancer-targeted therapy: Citrus flavonoids as potent chemopreventive agents. Asian Pac. J. Cancer Prev. 2012, 13, 427-436. [CrossRef]

301. Manzoor, Z.; Nawaz, A.; Mukhtar, H.; Haq, I. Bromelain: Methods of Extraction, Purification and Therapeutic Applications. Braz. Arch. Biol. Technol. 2016, 59. [CrossRef]

302. Abdullah, A.S.H.; Mohammed, A.S.; Abdullah, R.; Mirghani, M.E.S.; Al-Qubaisi, M. Cytotoxic effects of Mangifera indica L. kernel extract on human breast cancer (MCF-7 and MDA-MB-231 cell lines) and bioactive constituents in the crude extract. BMC Complement. Altern. Med. 2014, 14. [CrossRef]

303. Gawlik-Dziki, U.; Jezyna, M.; Świeca, M.; Dziki, D.; Baraniak, B.; Czyz, J. Effect of bioaccessibility of phenolic compounds on in vitro anticancer activity of broccoli sprouts. Food Res. Int. 2012, 49, 469-476. [CrossRef]

304. De Sales, N.F.F.; Da Costa, L.S.; Carneiro, T.I.A.; Minuzzo, D.A.; Oliveira, F.L.; Cabral, L.M.C.; Torres, A.G.; El-Bacha, T. Anthocyanin-rich Grape Pomace Extract (Vitis vinifera L.) from wine industry affects mitochondrial bioenergetics and glucose metabolism in human hepatocarcinoma HepG2 cells. Molecules 2018, 23. [CrossRef]

305. Srisukh, V.; Tribuddharat, C.; Nukoolkarn, V.; Bunyapraphatsara, N.; Chokephaibulkit, K.; Phoomniyom, S.; Chuanphung, S.; Srifuengfung, S. Antibacterial activity of essential oils from citrus hystrix (makrut lime) against respiratory tract pathogens. Sci. Asia 2012, 38, 212-217. [CrossRef]

306. Francki, R.; Fauquet, C.; Knudson, D.; Brown, F. Classification and Nomenclature of Viruses: Fifth Report of the International Committee on Taxonomy of Viruses. Virology Division of the International Union; Springer: Berlin/Heidelberg, Germany, 2012.

307. Muhire, B.; Martin, D.P.; Brown, J.K.; Navas-Castillo, J.; Moriones, E.; Murilo Zerbini, F.; Rivera-Bustamante, R.; Malathi, V.G.; Briddon, R.W.; Varsani, A.; et al. A genome-wide pairwise-identity-based proposal for the classification of viruses in the genus Mastrevirus (family Geminiviridae). Arch. Virol. 2013, 158, 1411-1424. [CrossRef] [PubMed]

308. Krupovic, M. Recombination between RNA viruses and plasmids might have played a central role in the origin and evolution of small DNA viruses. BioEssays 2012, 34, 867-870. [CrossRef] [PubMed]

309. Weitzman, M.D.; Fradet-Turcotte, A. Virus DNA Replication and the Host DNA Damage Response. Annu. Rev. Virol. 2018, 5, 141-164. [CrossRef] [PubMed]

310. Friedman, M. Antibacterial, antiviral, and antifungal properties of wines and winery byproducts in relation to their flavonoid content. J. Agric. Food Chem. 2014, 62, 6025-6042. [CrossRef] [PubMed]

311. Ho, S.C.; Kuo, C.T. Hesperidin, nobiletin, and tangeretin are collectively responsible for the anti-neuroinflammatory capacity of tangerine peel (Citri reticulatae pericarpium). Food Chem. Toxicol. 2014, 71, 176-182. [CrossRef] 
312. Tang, K.; He, S.; Zhang, X.; Guo, J.; Chen, Q.; Yan, F.; Banadyga, L.; Zhu, W.; Qiu, X.; Guo, Y. Tangeretin, an extract from Citrus peels, blocks cellular entry of arenaviruses that cause viral hemorrhagic fever. Antivir. Res. 2018, 160, 87-93. [CrossRef]

313. Xu, J.J.; Liu, Z.; Tang, W.; Wang, G.C.; Chung, H.Y.; Liu, Q.Y.; Zhuang, L.; Li, M.M.; Li, Y.L. Tangeretin from Citrus reticulate Inhibits Respiratory Syncytial Virus Replication and Associated Inflammation in Vivo. J. Agric. Food Chem. 2015, 63, 9520-9527. [CrossRef]

314. Shie, P.-H.; Huang, R.-L.; Lay, H.-L. Pharmaceutica Analytica Acta an open access journal The Flavonoids in Citrus madurensis Lour and their Anti-Hepatitis B Virus Activity. Pharm Anal Acta 2013, 4, 5. [CrossRef]

315. Hu, Z.; Hu, J.; Ren, F.; Xu, H.; Tan, M.; Wang, Q.; Ren, J. Nobiletin, a novel inhibitor, inhibits HBsAg production and hepatitis B virus replication. Biochem. Biophys. Res. Commun. 2020, 523, 802-808. [CrossRef]

316. Lin, S.; Chen, M.; Li, S.; Lin, C.; Wang, T. Antiviral activity of nobiletin against chikungunya virus in vitro. Antivir. Ther. 2017, 22, 689-697. [CrossRef] [PubMed]

317. Cui, J.; Li, F.; Shi, Z.-L. Origin and evolution of pathogenic coronaviruses. Nat. Rev. Microbiol. 2019, 17, 181-183. [CrossRef] [PubMed]

318. Boopathi, S.; Poma, A.B.; Kolandaivel, P. Novel 2019 coronavirus structure, mechanism of action, antiviral drug promises and rule out against its treatment. J. Biomol. Struct. Dyn. 2020, 1-10. [CrossRef] [PubMed]

319. Haque, A.; Pant, A.B. Efforts at COVID-19 Vaccine Development: Challenges and Successes. Vaccines $2020,8,739$. [CrossRef] [PubMed]

320. Poland, G.A.; Ovsyannikova, I.G.; Kennedy, R.B. SARS-CoV-2 immunity: review and applications to phase 3 vaccine candidates. Lancet 2020, 396, 1595-1606. [CrossRef]

321. World Health Organization. Draft Landscape of COVID-19 Candidate Vaccines. 2020. Available online: https: / /www.who.int/ publications/m/item/draft-landscape-of-covid-19-candidate-vaccines (accessed on 13 December 2020).

322. Gadhvi, K.; Vyas, S.; Karetha, K. Peelings of citrus fruits as a precious resource of phytochemical and vital bioactive medicines during Covid: 19 periods. Int. J. Bot. Stud. 2020, 5, 342-344.

323. Haggag, Y.A.; El-Ashmawy, N.E.; Okasha, K.M. Is hesperidin essential for prophylaxis and treatment of COVID-19 Infection? Med. Hypotheses 2020, 144. [CrossRef] 